\title{
Agentes dinámicos en la enseñanza del diseño gráfico
}

León Felipe Irigoyen Mónica Aguilar Tobin Andrés Elizalde García (COORDINADORES)

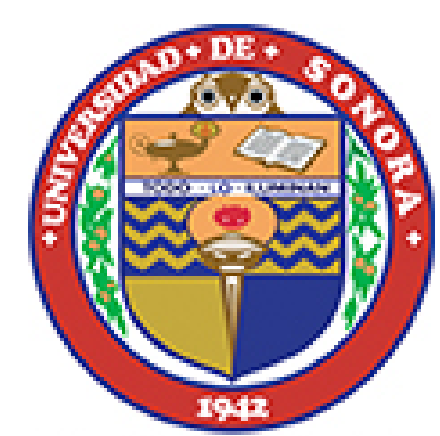

El saber de mis hijos hará mi grandeza

Qartuppi.

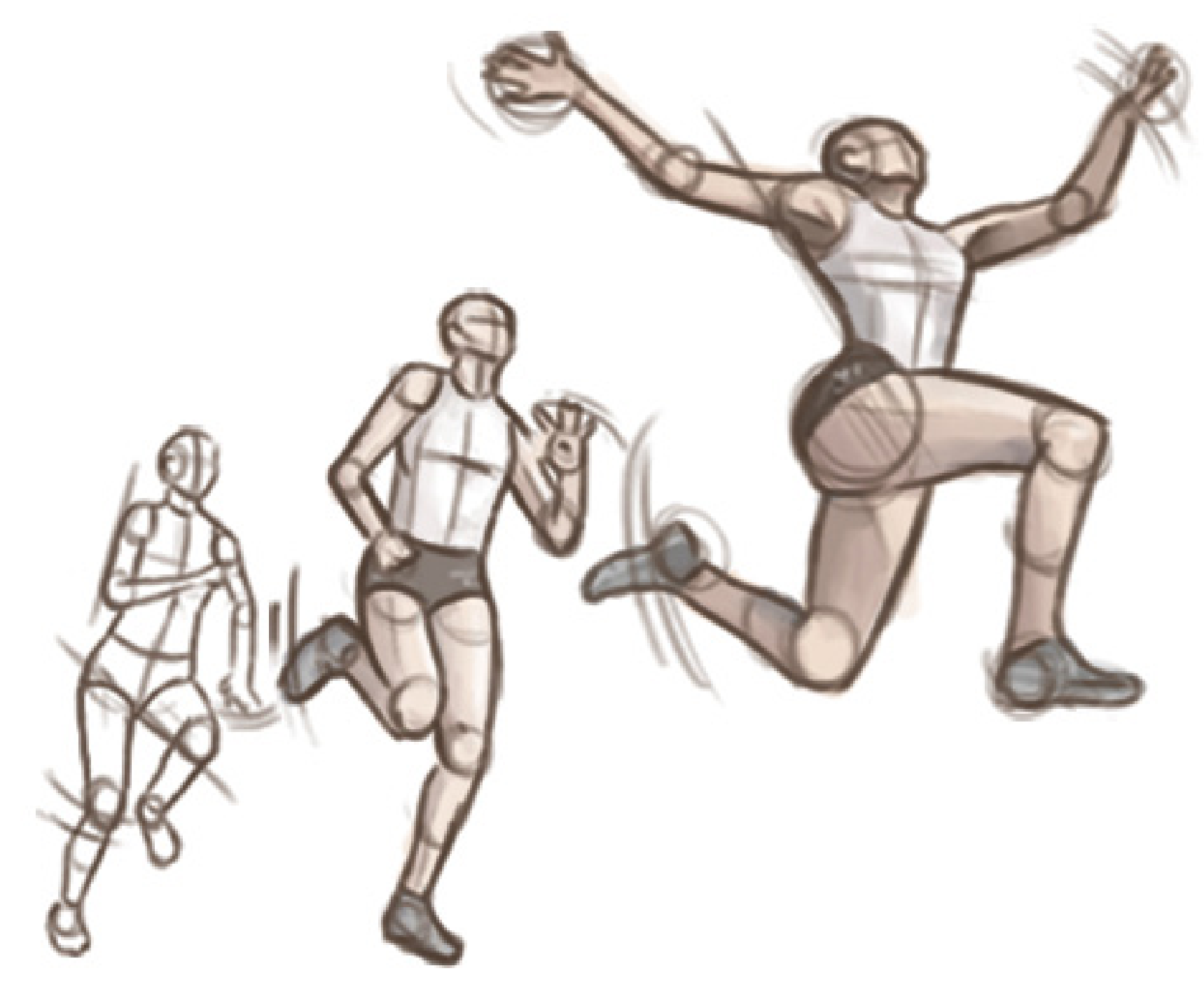




\section{CLÁUSULA DE EXENCIÓN DE RESPONSABILIDAD EDITORIAL}

Los puntos de vista, opiniones y posiciones expresadas son únicamente propiedad de los autores y/o proveedores de contenido; y no necesariamente reflejan o coinciden con los de la Universidad de Sonora, Qartuppi, S. de R.L. de C.V. o ningún socio comercial, empleado, proveedor o colaborador de dichas instituciones.

La Universidad de Sonora y Qartuppi, S. de R.L. de C.V. renuncian a la responsabilidad que pudiera llevar la certeza, validez, utilidad, integridad, impacto, implicaciones o derivaciones legales que cualquier parte del contenido aquí publicado tenga o pueda llegar a tener en cualquier momento. A su vez, no se asume responsabilidad alguna en relación con lo apropiado, correcto o completo de la información aquí expresada; ni de las pérdidas, problemas, daños o perjuicios derivados por su uso o reproducción posterior.

La presente cláusula de exención de responsabilidad no tiene por objeto limitar la responsabilidad de la Universidad de Sonora y/o de Qartuppi, S. de R.L. de C.V. de forma contraria a la dispuesto por las normativas nacionales aplicables, ni excluir su responsabilidad en los casos en los que, en virtud de dichas normativas, no pueda excluirse. 
Agentes dinámicos en la enseñanza del diseño gráfico

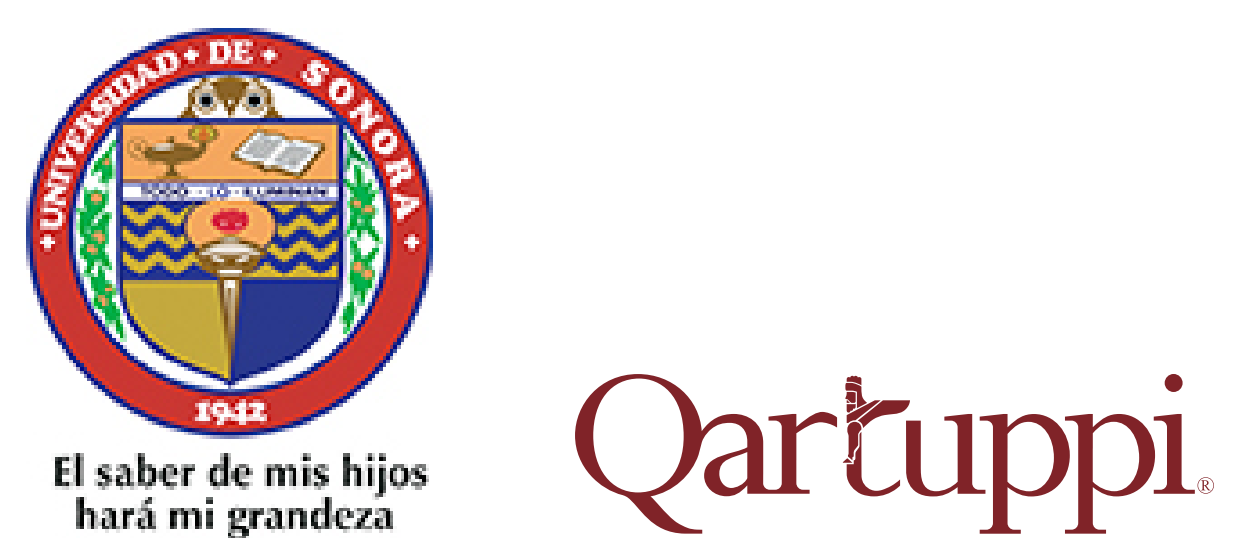


Agentes dinámicos en la enseñanza del diseño gráfico

lera. edición, Septiembre 2015.

ISBN 978-607-518-134-9

ISBN 978-607-96359-2-3

DOI I0.294IO/QTP.I5.OI

D.R. (C) 2015. Universidad de Sonora

Blvd. Luis Encinas y Rosales s/n Col. Centro. Hermosillo, Sonora 83000 México

http://www.uson.mx

D.R. (C) 20I5. Qartuppi, S. de R.L. de C.V. Calle Real 63, Col. Villa Satélite Hermosillo, Sonora 83200 México http://www.qartuppi.com
Edición y Maquetación:

Qartuppi, S. de R.L. de C.V.

Ilustración de Portada:

Arym Hernández Shepperd

Revisión Técnica:

Cecilia Ramírez León

Universidad Pedagógica y Tecnológica de Colombia

Virginia Meribeth Oropeza Gorocia Universidad Anáhuac Mayab

Irene Marincic Lovriha Universidad de Sonora

Dafné Flores Martínez

Universidad Autónoma de Guadalajara, Campus Tabasco 


\section{Contenido}

\section{Presentación}

Agentes Dinámicos

León Felipe Irigoyen, Mónica Aguilar Tobin,

Andrés Elizalde García

\section{Primera Parte - Didáctica}

Capítulo I

La didáctica en el diseño gráfico

¿Qué, cómo y para qué enseñar?

Cynthia Isabel Zatarain Bastidas

\section{Capítulo 2}

Formando Diseñadores Creativos

Patricia Sandoval Murillo

Capítulo 3

Estrategia didáctica basada en el aprendizaje lúdico

de anatomía tipográfica

Cynthia Lizette Hurtado Espinosa, Irma Lucía Gutiérrez Cruz,

Eva Guadalupe Osuna Ruiz, Lourdes Anette Orozco Guzmán

Capítulo 4

Videotutoriales para representación gráfica

Rosa María Mendoza Robles, Mario Yadir Rendón Sallard, Fernando Saldaña Córdova

\section{Segunda Parte - Aplicación}

6 Capítulo 5

Diseño de personajes para videojuegos

Iván Omar González Dávalos

Capítulo 6

9 Estrategias didáctica asociadas al uso de programas computacionales para la composición en el diseño Andrés Abraham Elizalde García

Capítulo 7

I6 El metalenguaje del branding y su aplicación en las ciudades Aurora García García de León

\section{Tercera Parte - Innovación}

Capítulo 8

Propuesta taxonómica para las áreas subdisciplinares del diseño gráfico

León Felipe Irigoyen Morales

\section{Capítulo 9}

\section{Mónica del Carmen Aguilar Tobin}

Capítulo 10

Aplicación del proceso de Design Thinking al diseño gráfico Alejandra Rivera Arredondo 


\section{Agentes dinámicos}

\section{León Felipe Irigoyen}

Mónica Aguilar Tobin

Andrés Elizalde García
Este libro representa una muestra de la actividad didáctica y la creación de propuestas que promueven la innovación y amplían áreas docentes. Agentes dinámicos en la enseñanza del diseño gráfico está circunscrito en el marco del Coloquio de innovación en eldiseño, organizadopor la Academia de Investigacióne Innovación en Diseño (AlID), del Departamento de Arquitectura y Diseño de la Universidad de Sonora (México), instancia fundamental en la creación de iniciativas que soporten y promueven la enseñanza crítica del diseño gráfico a nivel superior. El objetivo de dicho coloquio es promover y difundir el quehacer académico de generación y aplicación del conocimiento, a través del análisis y el diálogo con los distintos actores de la enseñanza del diseño, además de acercar y vincular las partes que estudian y ejercen el diseño para que mediante sus metodologías, uso de tecnología o estrategias didácticas, impacten de forma positiva la evolución del diseño gráfico.

Esta obra recopila en 10 capítulos el trabajo de 15 autores de distintas instituciones de educación superior de México que en sus planteamientos y labor didáctica contribuyen a la dinámica de la enseñanza y práctica del diseño gráfico.

El contenido de la obra se ha dividido en tres partes: didáctica, aplicación e innovación. En la primera parte se enfatiza la importancia de la didáctica en la formación profesional de las nuevas generaciones de diseñadores, el deber del docente en la creación de nuevos métodos de enseñanza que faciliten el aprendizaje de los estudiantes, la utilidad de las tecnologías de la información, la comunicación en el proceso de aprendizaje, el 
papel que juega el diseñador gráfico a nivel social y la pertinencia de cuidar su formación académica y creativa para poder contribuir socialmente ante una época de constantes cambios, proponiendo técnicas que ayuden a estimular la creatividad de los estudiantes.

La segunda parte se enfoca a las aplicaciones del diseño gráfico en la actualidad, a su evolución constante, las estrategias didácticas asociadas al uso de herramientas tecnológicas y la manera en que éstas han revolucionado la forma de hacer diseño. Se hace énfasis en las nuevas estrategias de aprendizaje en el diseño, así como en la misión, como facilitadores y formadores en el proceso educativo, de crear nuevos modelos que promuevan el desarrollo de los individuos en la sociedad y del pensamiento para utilizar adecuadamente la nueva tecnología. Asimismo, en esta sección, se reconocen las aportaciones del diseño gráfico en algunas de las industrias y su rol en la vida contemporánea, a través de la comunicación visual, que rara vez es percibida de manera consciente, pero que se convierte en parte de la cultura humana y de su identidad.

En la tercera parte, enfocada a la innovación, se propone la clasificación del diseño gráfico en áreas a partir de su campo de estudio, y por otra parte, resalta la idea de redefinición del diseño gráfico, destacando su acercamiento a prácticas sustentables y criterios éticos que consideren los efectos del diseño en el ser humano, la sociedad y el ámbito económico. Se considera la integración del proceso de Design Thinking en el diseño gráfico y se propone como herramienta para desarrollar proyectos de innovación social.

En conjunto, esta obra es un esfuerzo para asegurar que los capítulos que la componen impacten positivamente en el campo del diseño gráfico, transmitiendo las ideas y propuestas de los académicos participantes, a los cuales se agradece su compromiso y colaboración. También, se hace extensivo el agradecimiento a los revisores técnicos, quienes proporcionaron una guía valiosa para dirigir los esfuerzos en la mejora de la edición; a los estudiantes que intervienen constantemente e impulsan el desarrollo de nuevas ideas; a las instituciones de educación superior que promueven el desarrollo de eventos académicos y publicaciones como ésta. Y específicamente los miembros que componen la Academia de Investigación e Innovación en Diseño (AlID) agradecen el apoyo brindado por la División de Humanidades y Bellas Artes de la Universidad de Sonora para la realización de esta obra.

Finalmente, esta publicación busca ser la iniciadora de una serie de espacios destinados al intercambio de ideas y a la promoción del trabajo docente en diseño, área un tanto relegada en el esquema de la investigación académica.

Se hace extensiva la invitación a promover y difundir libremente esta publicación, así como el trabajo, las ideas y las metodologías empleadas por las instituciones, profesores, investigadores y alumnos (entendidos como los agentes dinámicos) que forman el conjunto educativo y formativo del diseño. 


\section{Primera parte}

Didáctica
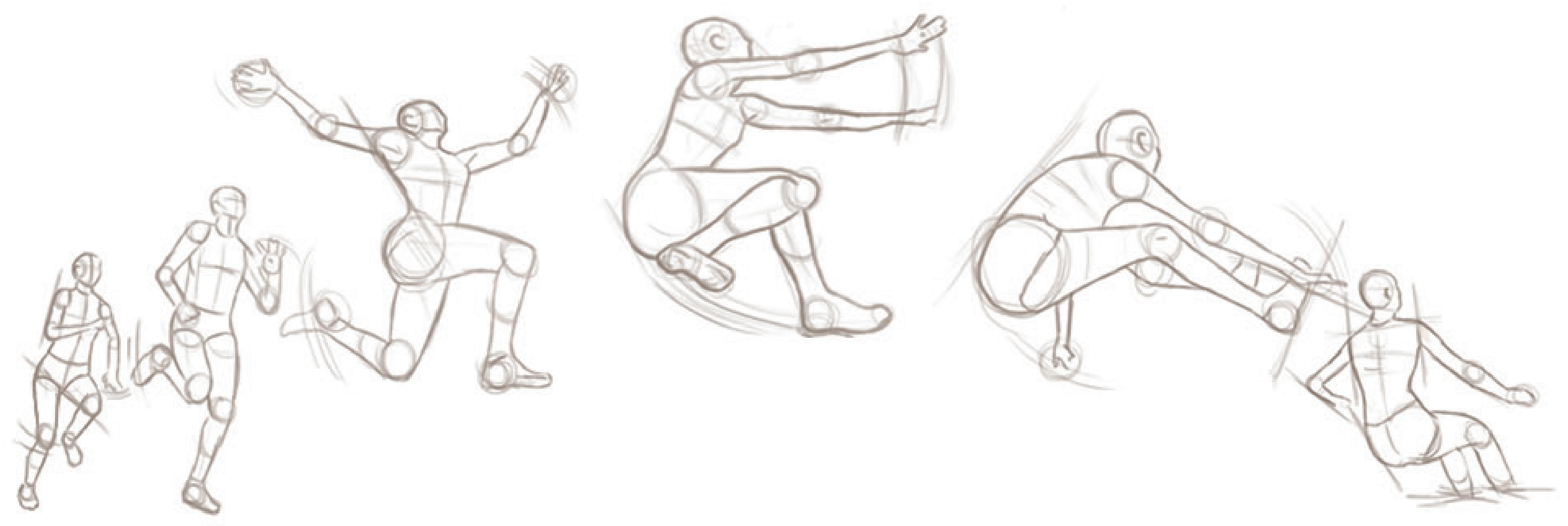


\section{La didáctica en el diseño gráfico ¿Qué, cómo y para qué enseñar?}

\author{
Cynthia Isabel Zatarain Bastidas
}

La mayoría de los profesionistas del diseño gráfico que ejercen funciones docentes, los cuales son encargados de la formación profesional de la nueva generación de diseñadores, tienen poco o nulo conocimiento sobre aspectos pedagógicos. Esto es crucial ya que tener este dominio es un parteaguas para el éxito en el proceso de enseñanza aprendizaje. Ante esto, Norberto Chaves (2008) afirma que la enseñanza del diseño en general, es una profesión carente de reflexión sobre sí misma. Por lo anterior, es importante cuestionar a los maestros qué tanto saben sobre didáctica, identificar si implementan estrategias de enseñanzaaprendizaje y cómo repercute su ausencia en la formación del diseñador.

Al hablar de didáctica se hace referencia al arte de enseñar. El concepto fue usado desde el s. XVII por Ratke y Comenio. En sí, la didáctica se encarga de facilitar el proceso de aprendizaje con la implementación de estrategias, en las cuales tiene que contemplar el objetivo, trabajo colaborativo, rescate de conocimientos previos y otros elementos sustantivos (Díaz y Hernández, 1999). De la Aplicar estrategias didácticas de manera asertiva en un contexto determinadoayudaafomentarenelalumnolainiciativadeaprender a aprender, es decir, que logre aprender permanentemente. Delors (1994) plantea que la educación durante toda la vida se presenta como una de las llaves de acceso al s. XXI.

Es importante como punto de partida definir qué es el diseño gráfico. Es necesario partir de que un buen diseño tiene que comunicar y lograr el objetivo por el cual fue solicitado. Ante esto, podría definirse como aquel elemento visual que nos comunica 
pertinentementealgo. Hay que tenermuchocuidado denodelimitar esta profesión como algo meramente pragmático: realizar gráficos bonitos y que logren comunicar el mensaje. Esta es una concepción muy lejana de la realidad, un verdadero profesionista sabe que existe un trasfondo más complejo. En resumen, no cualquiera puede realizar un buen diseño. Para solucionar problemáticas de esta índole es necesario una rigurosa formación profesional: diseñadores competentes, con una formación integral.

¿A qué se hace referencia cuando se habla de diseñadores competentes? Son aquellos profesionistas que cuentan con los conocimientos, habilidades y actitudes necesarias para ajustarse a los cambios y a la evolución del contexto, es decir, aprenden a vivir en la incertidumbre para solucionar las diversas problemáticas que se le presenten.

Por lo tanto, ya no es suficiente el dominio de una serie de conceptos y teorías, ni tampoco manejar software moderno. Actualmente es necesario el desarrollo de competencias en torno a la creatividad, trabajo colaborativo, expresión y defensa de ideas, cómo vender su trabajo, cómo conseguir clientes, argumentación, identificación y resolución de problemáticas. Por esto mismo, el proceso de formación de estos futuros diseñadores tiene que estar centrado en ellos mismos, en su aprendizaje. Como lo afirma Belluccia (2007) "el maestro debe plantear problemas de dificultad creciente y guiar al estudiante en sus sucesivos acercamientos a la solución". Es decir, ya el docente se encarga de planificar la estrategia y dejar que el alumno desarrolle sus procesos cognitivos.

En el análisis de los escenarios educativos (Hernández, 2006) se encuentran diversos enfoques que engloban el cómo enseñar, cómo evaluar, cómo percibir al alumno y al docente:
- Tradicional (teoría conductista): están centrados en el maestro, él es quien se encarga de dirigir y llevar la clase, los alumnos se limitan a tomar notas y reproducir lo aprendido en los exámenes, aplicándose como estrategia la memorización. Aquí la comunicación es vertical, solo del docente al alumno.

- Constructivistas (teoría psicogenética, constructivista, sociocultural, competencias): el alumno adquiere un rol más activo, la comunicación es horizontal, de maestro al alumno y viceversa, así como la retroalimentación entre compañeros. Las ideas y propuestas se debaten, se toman en cuenta las necesidades de los estudiantes para diseñar la clase. Los alumnos reflexionan y construyen sus propias concepciones fomentando el aprendizaje significativo.

Tomando las necesidades del contexto actual es necesario formar a los alumnos bajo enfoques constructivistas donde se desarrollen las competencias más idóneas a su profesión y puedan ejercer plenamente ante los cambios vertiginosos.

¿Quién es la persona más idónea para formar a estos profesionistas competentes del diseño? Esta interrogante causa mucha polémica, por lo cual, lo primero que se puede venir a la mente es un diseñador con práctica y experiencia, pero el hecho de que los alumnos tengan al mejor diseñador como docente no es sinónimo de que ellos logren apropiar lo necesario para convertirse en competentes.

Una persona encargada de formar a los futuros diseñadores tiene que ser un profesionista que domine el área, pero también tener en su formación un área pedagógica para implementar estrategias didácticas: saber cuándo, cómo y con qué objetivos aplicarlas. Muchos maestros educan tal como fueron educados y se reproducen los errores y fomentan una educación más tradicional que enfocada a las nuevas necesidades, formando profesionistas obsoletos, no preparados para el cambio. 
Sánchez y Aguilera (2010) afirman que cuando se carece de esa formación didáctica, improvisa estrategias didácticas, no tiene claro el objetivo de su clase ni qué enseña, descuida el elemento más importante: el aprendizaje, por lo cual puede caerse fácilmente en el desinterés por parte de los alumnos.

Para lograr una implementación plena de estrategias didácticas, es necesario que el docente inicie con desglosar qué va a enseñar, cómo y para qué.

\section{¿Qué enseñar?}

En todos los programas, y particularmente en todas las asignaturas, existe una clasificación de aprendizajes: conceptuales, procedimentales y actitudinales. Para formar individuos con un enfoque integral y el desarrollo de competencias es necesario considerar cada una de ellas para el diseño de estrategias.

Es necesario identificar primeramente cuáles son los conocimientos teóricos de la materia asignada: conceptos, temas, problemáticas. Retomando la formación general del diseñador, su parte conceptual podría desglosarse así: manejo del color, tipografía, elementos del diseño, publicidad, semiótica, comunicación, ética, métodos de investigación, historia del arte, mercadotecnia, etc.

Ahora bien, el hecho de que los estudiantes dominen esa parte conceptual no es suficiente, necesitan saber cómo aplicarla a hechos reales y concretos, es decir, desarrollar en ellos las habilidades para que pueda llevar a la práctica todo lo aprendido. La parte procedimental considera: manejo y dominio de software diverso, aplicación de color, investigación, campañas publicitarias, proyectos, diagnóstico y análisis de problemáticas visuales.

Otra cuestión de suma importancia que en varias ocasiones se deja de lado, son las actitudes, esto es sustancial formar en el alumnado, ya que le permitirá sobrellevar situaciones complicadas y amoldarse fácilmente a este mundo de cambios.
Parte actitudinal: es conveniente que desarrolle la creatividad, el trabajo en equipo, la solución de problemáticas, la responsabilidad, la toma de decisiones, aprender de manera autónoma y significativamente. González (20II) afirma la iniciativa de tener una asignatura donde se les enseñe a los alumnos estrategias metacognitivas para que concienticen sobre su proceso de aprendizaje.

De los aprendizajes conceptuales, procedimentales y actitudinales se puede desglosar un conjunto de competencias profesionales del diseñador gráfico':

I. Diagnosticar problemas y necesidades de comunicación visual del hombre en su relación con el entorno.

2. Crear estrategias que den solución a problemas de comunicación visual, relacionadas con el diseño gráfico.

3. Diseñar mensajes visuales pertinentes y significativos en contextos determinados.

4. Especificar y dirigir los procesos de producción de los mensajes visuales en diversos entornos y medios.

5. Gestionar proyectos de diseño gráfico que den respuesta a diversas necesidades y demandas contextuales pertinentes.

\section{Reflexión de teoría y práctica}

Otra cuestión de suma importancia dentro de la didáctica del diseño gráfico es el binomio de la teoría-práctica. Como se mencionaba al inicio, diseño podría caracterizarse por ser una profesión meramente pragmática, lo cual tiene una fracción de certeza, pero también debe imperar un conjunto de saberes teóricos que sirvan como antecedente y punto de partida a la práctica. Si no se implementa ese proceso reflexivo, no se estaría hablando de un trabajo profesional competente, el diseñador tiene que saber cómo llevar

Propuesta de reestructuración curricular (2013). Universidad Autónoma de San Luis Potosí. 
a la práctica todo lo aprendido, pero en el proceso puede evaluar su avance y si considera necesario analizar si eso realmente solucionará las problemáticas o debecambiar las dinámicas. Necesitando una fuerte integración entre el trabajo teórico y práctico.

Heiner (199I) la comparte muy bien al hablar de su experiencia como docente: primeramente facilitaba la teoría como sustento antes de iniciar los proyectos, para que el alumno lograra comprender todo lo que implementara, pero después vio la necesidad de empezar directamente con la práctica y en el transcurso de ella ir insertando los conceptos y teorías necesarias en torno a las dudas e inquietudes que los alumnos tuvieran. Por esto mismo, la importancia de tener el instinto pedagógico, para identificar en qué momento es necesario cambiar la dinámica o seguir como se había planteado en la planeación.

El modelo por competencias toma como estándar la relación intrínseca entre teoría y práctica, binomio que debe ser apropiado por los estudiantes en su proceso de formación.

\section{¿Cómo enseñar?}

El proceso de cómo enseñar tiene que ver directamente con la didáctica de cada docente, cada uno trae de manera implícita conocimientos previos de cómo realizarla correctamente, por lo regular definida por la experiencia de algún profesor que haya inspirado su formación académica.

El docente debe tener muy claro qué enseñar, cómo va a transmitir lo que quiere enseñar y para qué lo considera necesario. Por más dominio que tenga de la materia, si no se plantea y se deja claro esto, es difícil que se logre formar un profesionista competente. Por lo anterior, es necesario que cada profesor identifique lo siguiente:
- ¿Qué objetivo quiere alcanzarenesta clase/taller/asignatura?

- ¿Qué conocimientos previos tienen los alumnos acerca de la temática?

- ¿Qué temáticas y conocimientos son los más pertinentes al objetivo planteado?

- ¿Qué recursos son necesarios?

- ¿Qué estrategia es necesaria implementar para el desarrollo de lo que se quiere que los alumnos alcancen?

- ¿Cómo se va a evaluar?

- ¿Cuál es el aprendizaje esperado por el alumno?

Es muy importante definir y dejar claro qué se pretende que el alumno aprenda, desde lo conceptual, procedimental y actitudinal, ya que será la pauta del diseño de las actividades.

El hecho de identificar los conocimientos previos del alumno es un punto de partida para lograr el aprendizaje significativo ${ }^{2}$, por esto mismo el docente debe de conocerlos. Este rescate de conocimientos previos pueden identificarse mediante preguntas al inicio de clase poniendo en relieve los conceptos más importantes que se abordarán (Díaz y Hernández, 1999).

Otro binomio a considerar es el trabajo individual y colaborativo, es importante desarrollar ambos para fomentar una educación integral. El trabajo colaborativo fomenta la retroalimentación de ideas, su defensa y el logro de acuerdos aunque haya puntos de vista divergentes.

Igualmente, la planta docente debe ser un equipo integrado que se reúna consecutivamente para retroalimentar sobre sus experiencias y trabajar proyectos interdisciplinares con los alumnos.

2 Concepto implementado por Ausubel, el cual se define como el proceso donde se relaciona un nuevo conocimiento o información con la estructura cognitiva existente en la persona que aprende. 


\section{El método de proyectos como estrategia didáctica}

Una de las estrategias más funcionales dentro del campo del diseño gráfico es la enseñanza a través de proyectos (Zavarse, Ferrer y Ferrari, 2013), iniciativa aportada por Kilpatrick que identifica cuatro etapas:

- Propuesta

- Planificación

- Elaboración

- Evaluación

En la primera etapa se desarrolla la propuesta, en la cual debe quedar bien definida la temática: si se va a entregar una investigación, un cuadro sinóptico, una exposición, una maqueta, una revista, etc. De la misma manera, identificar qué se pretende con ello, es decir, los objetivos. Por último, seleccionar el tiempo para el desarrollo del proyecto: una clase, una semana, un semestre. Se recomienda empezar con proyectos cortos y conforme el docente se vaya apropiando de la dinámica, hacerlos más extensos.

En la etapa de planificación se debe desglosar primeramente los aprendizajes esperados, los cuales serán pauta para el diseño de actividades y su dosificación en los tiempos establecidos. En el proceso de planeación, el papel del docente es planear de manera muy meticulosa los proyectos y entregar este producto a los alumnos para que desde un inicio estos sepan qué van a realizar, qué va a ser contemplado en la evaluación, cuáles son los aprendizajes esperados y estén conscientes de los tiempos para su mejor administración (Zavarse et al., 2013; Heiner, 199I).

La tercera etapa consiste en la elaboración del proyecto, en la que es vital que el docente muestre presencia en todo el proceso para revisar avances, solucionar dudas y reflexionar sobre toda la dinámica.

La última etapa contempla un elemento sustantivo en el desarrollo de proyecto: la evaluación. En enfoques tradicionales, el docente es el único que tiene esta tarea, pero en los nuevos modelos centrados en el alumno, es necesario desarrollar una autoevaluación para que él mismo haga un autoanálisis de su proceso de formación e identifique sus áreas de oportunidad, esto ayuda a fomentar un pensamiento más crítico. También puede implementarse la coevaluación, puedan evaluarse por binas, entre los mismos compañeros; el hecho de identificar debilidades en sus iguales, hará más fácil identificar los suyos. Lo más idóneo es exponer el trabajo finalizado frente a los demás y entre todos evaluar todo el proceso.

\section{¿Para qué se enseña?}

El docente debe estar consciente que al alumno no se le va a formar para cumplir una función en específico: diseñar. Tiene que tener un trasfondo en el que el profesionista pueda insertarse en diversos contextos y desarrolle aprendizajes de cómo comunicar sus ideas, defenderlas, trabajar de manera colaborativa e individual, creatividad para solución de problemáticas, sepa investigar, analizar e identificar lo significativo. Es decir, formar profesionistas competentes con formación integral que puedan desenvolverse plenamente. Por lo tanto, las estrategias implementadas en su proceso de formación tienen que ir orientadas a formar ese tipo de profesionista.

\section{Conclusiones}

Por las características de la nueva sociedad en la que estamos insertos, es importante desarrollar un papel más activo en el alumno, que las estrategias estén centradas en su aprendizaje para fomentar el conjunto de conocimientos, habilidades y actitudes necesarias para desarrollarse competentemente en su área. Uno de los métodos más idóneos es la implementación de proyectos.

También es vital mantener retroalimentación constante con el alumno en su proceso de formación, de esta manera él estará 
consciente de cómo va, qué necesita reforzar y podrá aplicar estrategias metacognitivas. Es importante recalcar que para que se lleve a cabo todo lo anterior, los encargados de la formación de estos futuros diseñadores tienen que ser profesionistas en su área, pero a la par que tengan conocimientos de pedagogía para llevar a cabo una didáctica acorde a lo planteado.

Para solventar la necesidad de la formación pedagógica en los docentes, las escuelas pueden tomar iniciativas de diseñar cursos para lograrlo, pero es importante que los docentes tengan seguimiento y den evidencia de cumplir con los objetivos. Cursos cortos y esporádicos no resolverían la problemática.

Es necesario formar equipos interdisciplinarios entre los docentes, para que exista diversidad de perfiles: diseñadores que ejercen, maestros con formación pedagógica y académica, y profesionistas con otros perfiles: artistas, tecnólogos, sociólogos. Este trabajo colaborativo se requiere para analizar la didáctica implementada, así como construir proyectos enfocados en los alumnos. De todo esto pueden surgir productos muy interesantes, desde investigaciones de la práctica del diseño hasta trabajos sistemáticos de cómo se lleva el proceso de formación del diseñador.

Lo anterior también puede incentivar a llevar ese trabajo colegiado a otras universidades y generar espacios para argumentar y retroalimentar ideas y proyectos de diversos contextos tanto regionales como nacionales, y de esta manera, crear más debate de la didáctica implementada en la formación de los diseñadores gráficos. Esta área está muy necesitada de investigación por lo cual sería una gran aportación. 


\section{Referencias bibliográficas}

Belluccia, R. (2007). El diseño gráfico y su enseñanza. llusiones y desengaños. Argentina: Paidós.

Chaves, N. (2008). Dos distorsiones en la enseñanza del diseño gráfico. Recuperado de http://foroalfa.org/articulos/dosdistorsiones-en-la-ensenanza-del-diseno-grafico

Delors, J. (1994). Los cuatro pilares de la educación. La educación encierra un tesoro. Informe a la UNESCO de la Comisión Internacional sobre la educación para el siglo XXI. Madrid: Santillana/UNESCO.

Díaz, F., \& Hernández, G. (1999). Estrategias docentes para un aprendizaje significativo. México: McGraw Hill.

González, M. (20II). Estilos de aprendizaje, su influencia para aprender a aprender. Revista Estilos de aprendizaje 7(7). Recuperado de http://www.uned.es/ revistaestilosdeaprendizaje/numero_7/articulos/lsr_7_ articulo_I2.pdf
Heiner, J. (199I). Un enfoque integrado de la enseñanza del diseño gráfico. Temmes de Disseny. Barcelona: Elisava Escuela Superior de Disseny. Recuperado de http://tdd.elisava.net/ coleccion/6/jacob-es

Hernández, G. (2006). Paradigmas en psicología de la educación. México: Editorial Paidós.

Sánchez, M.E., \& Aguilera J.M. (20I0). La enseñanza del diseño gráfico en base a las competencias profesionales. Encuentro Latinoamericano de Diseño. I Congreso Latinoamericano de enseñanza en Diseño. Recuperado de http://www.palermo. edu/dyc/congreso-latino/pdf/sanchez.pdf

Zavarse, E., Ferrer, M., \& Ferrari, V. (2013). Articulación de las estrategias de la enseñanza del diseño gráfico, como hacer reflexivo en el Programa de Diseño Gráfico de Luz. Revista de Formación e Innovación Educativa Universitaria. 6(3). Recuperado de http://webs.uvigo.es/refiedu/Refiedu/ Vol6_3/REFIEDU_6_3_I.pdf 


\section{Capítulo 2}

\section{Formando diseñadores creativos}

\author{
Patricia Sandoval Murillo
}

\section{Introducción}

\section{Planteamiento}

La creatividad para cualquier ser humano es indispensable para desarrollarse en la sociedad (Ziegler, 2000), por lo cual no debe verse como un lujo en el tiempo libre o sólo para las sociedades con un alto grado de desarrollo (Esteve, 2008). Por esta razón es pertinente agregar que debe motivarse a cualquier sujeto a no perderla y desarrollarla de forma continua a largo de su vida como parte de su formación integral. Más aún cuando se trata de labores relacionadas en forma directa con esta herramienta básica de la esencia del ser humano como en el caso de los estudiantes de carreras dedicadas a las áreas de las artes y diseño.

El trabajo del diseñador es un trabajo de comunicación social, que al mismo tiempo involucra la persuasión y la creatividad. El diseñador como profesionista debe ser un individuo creativo y ético, pues sus productos generalmente llegan a las masas en distintos ámbitos sociales, así que por el papel que juega un diseñador gráfico a nivel social es pertinente cuidar su formación académica y creativa para que así pueda contribuir socialmente ante una época de constantes cambios.

Frascara (2004) menciona varios supuestos y características de la profesión y la manera en la que esta se desarrolla en la sociedad.

- El diseño es una profesión dedicada a la comunicación visual dirigida a afectar el conocimiento, las actitudes y el comportamiento de la gente. 
- Afirma que las decisiones visuales relacionadas con la construcción de mensajes no se limitan a supuestos estéticos o simples caprichos, se desarrollan en un campo social con un sentido real en el que se desea dar mensajes y enfrentar de diversas formas, sutiles o contundentes, a la gente con la que se establece la relación visual.

- Sostiene que el diseñador le da forma visual a las comunicaciones pues su labor se caracteriza por procesos de decisión complejos, generalmente su investigación previa se dificulta debido al difícil acceso a los datos confiables y sus variables confusas tienden a dirigir el proyecto por distintos caminos, unos más claros que otros.

- Menciona que el diseñador tiene que tener la capacidad de reconocer las situaciones sociales en las que se desarrolla su trabajo y tomar decisiones para su profesión.

De esta forma se entiende que el diseñador debe ser capaz de elegir el camino correcto que comunicará de una manera más clara, pero siempre contundente y directa, e impactante y para esto necesita tener un manejo correcto de su creatividad.

Enfocado con una perspectiva positiva el diseño puede ser un medio para encarar problemáticas sociales ya que su influencia puede ejercer una importante tarea de persuadir, educar y formar.

\section{Objetivo}

Aportar propuestas claras para implementar dentro de las materias regulares de la carrera de diseño gráfico técnicas que ayuden a estimular la creatividad de los estudiantes.

\section{Pregunta de investigación}

¿Cómo fomentar la creatividad en los estudiantes de la licenciatura de Diseño Gráfico de la Universidad de Sonora para que esa vaya en aumento?

\section{Antecedentes}

Basándose en la investigación realizada en el semestre 2012-I (Sandoval, 2013) en la que se realizó una evaluación de la creatividad de los estudiantes de la carrera de diseño gráfico de la Universidad de Sonora, mediante un estudio de tipo descriptivo, no experimental, con una metodología cuantitativa, la cual se aplicó a los estudiantes de los semestres primero, tercero, quinto y séptimo. El instrumento que se utilizó para esta evaluación es denominado "Evaluación Multifactorial de la Creatividad" (EMUC) (Sánchez, 2006), en el que se evalúan varias dimensiones y categorías que caracterizan el quehacer creativo como lo son las dimensiones de Creatividad Visomotora, Aplicada o Inventiva y Verbal, en las que tomando como referencia las categorías de fluidez, flexibilidad y originalidad se determinan numéricamente los resultados del nivel creativo y así, además de hacerse una descripción de los resultados obtenidos se determinó que la muestra de estudiantes que se evaluó no presentaba una diferencia significativa entre semestres en sus niveles creativos.

La población estudiada fue de 368 estudiantes de la carrera de Diseño Gráfico del departamento de Arquitectura y Diseño de la Universidad de Sonora, campus Hermosillo, matriculados en el periodo agosto - diciembre 2012. A partir de un muestreo no probabilístico con un margen de error de 5\% y un 95\% de confianza, para que la muestra fuera representativa de la población se seleccionó a un total de 148 estudiantes, de los cuales 100 (67.1\%) son mujeres y 49 (32.8\%) son hombres. La edad promedio de los estudiantes fue de 20.5 con un rango entre 18 y 33 años

La distribución de estudiantes por semestre se hizo con estudiantes de primer semestre, 36 (24.1\%), de tercer semestre $33(22.14 \%)$, de quinto semestre $44(29.53 \%)$, de séptimo 34 (23.48\%). El total es de 148 estudiantes.

El instrumento "Evaluación Multifactorial de la Creatividad" EMUC, (Sánchez, 2006) se divide en diferentes apartados, el pri- 
mero de datos generales donde se pregunta al estudiante ciertas variables que aportan mayor información de los mismos en relación al estudio.

En una segunda parte se describen las tres dimensiones de la creatividad que evalúa:

a. dimensión verbal, se entiende como "La facilidad para crear un número elevado de ideas (Sánchez, 2006)

b. dimensión visomotora, se define como "Capacidad mediante la cual se transforma el proceso para alcanzar la solución del problema o el planteamiento de éste. Involucra una transformación, cambio, replanteamiento o una reinterpretación" (Sánchez, 2006)

c. dimensión Aplicada/inventiva, se refiere a encontrar diferentes usos y aplicaciones a los objetos de la vida cotidiana (Sánchez, 2006).

En cuanto al procedimiento, los participantes contestaron la prueba de acuerdo a los lineamientos establecidos con la finalidad que los datos obtenidos fueran confiables.

Los datos fueron capturados y analizados en una base de datos del programa estadístico SPSS.19. A continuación se muestras los principales resultados y sus tablas de promedios.

\section{Medias o promedios generales de los tres componentes de la creatividad}

El promedio obtenido por los participantes en las categorías que se relacionan con la creatividad visomotora muestra una media de 8.94 (D.S. =I.77) (Ver tabla I).

Los valores que cada uno de las categorías puede asumir van de 0 a 4 puntos. El promedio de cada una de los diferentes elementos de las tres dimensiones de la creatividad va de 0 a I2.
Tabla I. Medias y promedios de las 3 dimensiones.

\begin{tabular}{|l|l|l|l|l|}
\hline & & $\begin{array}{l}\text { Suma de las 3 } \\
\text { categorías de } \\
\text { la dimensión } \\
\text { visomotora }\end{array}$ & $\begin{array}{l}\text { Suma de las 3 } \\
\text { categorías de } \\
\text { la dimensión } \\
\text { inventiva }\end{array}$ & $\begin{array}{l}\text { Suma de las 3 } \\
\text { categorías de } \\
\text { la dimensión } \\
\text { verbal }\end{array}$ \\
\hline$N$ & Valid & 148 & 148 & 148 \\
\hline & Missing & 0 & 0 & 0 \\
\hline Mean & & 8.9459 & 7.6689 & 7.2568 \\
\hline Std. Deviation & & 1.77964 & 2.20123 & 1.79615 \\
\hline
\end{tabular}

\section{Promedios de las categorías que componen las tres dimensiones de la creatividad}

El promedio más alto se logró en la dimensión visomotora y el más bajo en la dimensión verbal.

En el caso de la Fluidez visomotora la media es de 1.87 (D.S. $=1.16)$, la flexibilidad visomotora tiene un promedio de 3.92 $(D . S .=0.43)$, en la originalidad visomotora el resultado de la media fue de 3.16 (D.S.=1.04).

En el caso de la Fluidez Aplicada o inventiva, la media es de 2.68 (D.S. 0.82), en el caso de la flexibilidad de esta misma dimensión la media que presenta es de 2.40 (D.S. 0.76) y en el caso de la originalidad de la dimensión aplicada o inventiva la media es de 2.59 (D.S 0.89).

La fluidez verbal, que es la puntuación más baja, se obtuvo un promedio de 0.62 (D.S .99), la flexibilidad verbal 3.75 (D.S. 65) y la originalidad verbal 2.89 (D.S. I.OI).

\section{Diferencias entre los tres componentes de la creatividad en función del semestre}

Para probar si existen diferencias en las tres dimensiones de creatividad tomando en cuenta el semestre que cursan los participan- 
tes en este estudio, se realizó un análisis de varianza. Como se muestra en las tablas 2 y 3, los resultados indican que no hay diferencias significativas en las tres dimensiones de creatividad en función del semestre que cursan.

Tabla 2. Resultados de promedios según análisis de varianza por semestre.

\begin{tabular}{|l|c|c|c|}
\hline Dimensiones & Semestre & Media & D.S. \\
\hline Dimensión visomotora & 1 & 8.67 & 2.16 \\
\cline { 2 - 4 } & 3 & 9.58 & 1.70 \\
\cline { 2 - 4 } & 5 & 8.89 & 1.54 \\
\cline { 2 - 4 } & 7 & 8.71 & 1.62 \\
\hline Dimensión aplicada/inventiva & 1 & 7.11 & 2.25 \\
\cline { 2 - 4 } & 3 & 7.94 & 2.14 \\
\cline { 2 - 4 } & 5 & 7.91 & 2.22 \\
\cline { 2 - 4 } & 7 & 7.69 & 2.17 \\
\hline Dimensión verbal & 1 & 6.58 & 2.44 \\
\cline { 2 - 4 } & 3 & 7.33 & 1.49 \\
\cline { 2 - 4 } & 5 & 7.66 & 1.40 \\
\cline { 2 - 4 } & 7 & 7.37 & 1.59 \\
\hline
\end{tabular}

Tabla 3. Resultados de promedios según análisis de varianza por dimensiones.

\begin{tabular}{|l|c|c|c|}
\hline Dimensiones & gl & F & Sig. \\
\hline Dimensión visomotora & 3 & 1.923 & 0.129 \\
\hline Dimensión aplicada/inventiva & 3 & I.II5 & 0.345 \\
\hline Dimensión verbal & 3 & 2.570 & 0.057 \\
\hline
\end{tabular}

\section{Diferencias entre los tres componentes}

\section{de la creatividad en función del género}

Para probar si existen diferencias en las tres dimensiones de creatividad tomando en cuenta el género de los participantes, se utilizó el procedimiento t de Student. Los resultados (ver tablas 4 y 5) indican que no hay diferencias significativas entre hombres y mujeres para las dimensiones visomotora y aplicada/inventiva. Sin embargo, las mujeres (media 7.755I D.S. I.61414) muestran significativamente $(t=-2.413, \mathrm{gl} .=146, \mathrm{p}=.017)$ mayores puntajes que los hombres (media 7.0IOI D.S. I.83778) en la dimensión verbal de la creatividad.

Tabla 4. Medias y D.S. de las tres dimensiones por género.

\begin{tabular}{|l|c|c|c|}
\hline Dimensiones & Género & Mean & $\begin{array}{c}\text { Std. Devia- } \\
\text { tion }\end{array}$ \\
\hline $\begin{array}{l}\text { Suma de las 3 categorías } \\
\text { de la dimensión visomotora }\end{array}$ & $F$ & 9.0000 & 1.81265 \\
\cline { 2 - 4 } & $M$ & 8.8367 & 1.72418 \\
\hline $\begin{array}{l}\text { Suma de las 3 categorías } \\
\text { de la dimensión aplicada/ } \\
\text { inventiva }\end{array}$ & $F$ & 7.5657 & 2.27413 \\
\cline { 2 - 4 } & $M$ & 7.8776 & 2.05277 \\
\hline $\begin{array}{l}\text { Suma de las 3 categorías } \\
\text { de la Dimensión verbal }\end{array}$ & $F$ & 7.7551 & 1.61414 \\
\cline { 2 - 4 } & $M$ & 7.0101 & 1.83778 \\
\hline
\end{tabular}

Tabla 5. Valores de la prueba t de Studen para las tres dimensiones por género.

\begin{tabular}{|l|c|c|c|}
\hline Dimensiones & $t$ & $g l$ & Sig. \\
\hline $\begin{array}{l}\text { Suma de los 3 elementos } \\
\text { de la dimensión visomotora }\end{array}$ & 0.524 & 146 & 0.601 \\
\hline Suma de elementos inventiva & -0.81 & 146 & 0.419 \\
\hline Suma de elementos verbal & -2.413 & 136 & 0.017 \\
\hline
\end{tabular}




\section{Propuesta}

Determinado entonces esos resultados se observa en ese estudio que los estudiantes de Diseño Gráfico de la Universidad de Sonora no presentan diferencias significativas en su nivel de creatividad entre semestres. Lo importante sería entender cómo trabaja la creatividad y si es posible mediante técnicas específicas tratar de manipular este resultado, es decir, si en lugar de establecer solo una materia de creatividad durante la carrera, sino dentro de las materias de toda la carrera, unidades, ejercicios, o técnicas que engloben cada uno de los temas que pongan en práctica las técnicas que la materia de creatividad propone y trabajar así durante un determinado tiempo para luego volver a aplicar la Evaluación Multifactorial de la Creatividad y entonces evaluar si hubo algún cambio significativo.

Es importante aclarar que el comportamiento de la creatividad puede variar y depender de muchas condiciones del entorno e incluso del estado de ánimo del individuo creativo, pero estas propuestas lo que intentan es establecer un cambio en el nivel creativo de los estudiantes al avanzar en sus estudios dentro de la licenciatura.

En el estudio mencionado anteriormente el promedio más alto se logró en la dimensión visomotora y el más bajo en la dimensión verbal. Esto debe estar directamente relacionado con la disciplina que desempeñan, ya que el trabajo de los diseñadores gráficos tiene una relación directa con lo visual, el manejo de gráficos, colores y formas. El ejercicio escrito lo desempeñan de manera menos formal que en otras áreas, y esto podría relacionarse directamente con los resultados.

La única diferencia significativa fue en la creatividad verbal entre hombres y mujeres. Las mujeres presentan mayor creatividad verbal que los hombres. En todos los resultados que arroja este estudio es la única diferencia significativa que se logra percibir. Sin embargo, este nivel creativo de "dimensión Verbal" en los diseñadores puede tratar de elevarse involucrándolos más en la lectura y redacción incluso de sus justificaciones de trabajo.

Así bien la propuesta consiste en establecer como parte del programa de todas las materias de la carrera, una unidad que se dedique exclusivamente a ejercicios que fomenten la creatividad, con relación a la materia que se esté llevando, es decir, que se implementen técnicas o ejercicios que estén relacionados con retos creativos para los estudiantes. De manera que se asegure que cada uno de los estudiantes se vea estimulado creativamente en todo su proceso de formación y así darle seguimiento a la materia denominada Taller de Creatividad.

La propuesta es que en esta unidad "creativa" de cada materia, los estudiantes trabajen individualmente o bien en parejas pero no en equipos más grandes, esto para enfatizar el desarrollo creativo del individuo y evitar que alguno se quede sin aprovechar estos ejercicios suponiendo que por sus características personales algunos de los estudiantes presentan mayor grado de liderazgo y extroversión que otros. Es decir, si en esta unidad "creativa" por materia los estudiantes trabajan individualmente, todos tendrán la misma oportunidad de desarrollar esta habilidad creativa y de irla incrementando.

Para no restar autonomía de cátedra al maestro, se puede sugerir algunos ejercicios o actividades dentro de esta unidad "creativa", dejando libertad al maestro de que las adapte a sus materias e incluso a los temas que el programa de cada materia está dictando.

Sabemos que todas las materias de Diseño Gráfico requieren de una dedicación técnica y creativa, pero con estos los resultados fueron los mismos, así que para intentar manipular este resultado se sugiere que se dedique una unidad completa que conste por ejemplo de cuatro temas únicamente dedicados a la creatividad.

Las estrategias didácticas que se presentan para la materia "Taller de Creatividad" son las siguientes: 
- Realización de ejercicios en los cuales se busquen soluciones creativas de primera intención.

- La creatividad del alumno se apoya estimulándolo a través de ejercicios que permitan realizar la representación a sus ideas.

- Reutilización y reciclaje de materiales que le permitan experimentar, plasmar y visualizar sus ideas.

- Técnicas de participación. Lectura y estudio de textos, material audiovisual, análisis y evaluación de los ejercicios planteados.

- Importante inducirlo al uso en sus ejercicios de la escala humana.

- Es de suma importancia que el alumno aprenda a diferenciar el recorrido visual, proporción, equilibrio, tono, unidad, emoción y cualidades.'

Así bien, en una materia Integral quizás parece más sencillo implementar una unidad "creativa", porque los puntos de las estrategias didácticas son naturalmente adaptables a este tipo de materias, pero ¿qué sucede con las materias teóricas?

La propuesta es que también en estas materias se establezcan retos creativos, por unidades o bien en cada uno de los temas que se imparten. De manera que en las materias de Historias por ejemplo los estudiantes pueden realizar un ejercicio creativo al finalizar cada tema, que se encargue de englobar los retos que proponen las estrategias didácticas de la materia de "Taller de creatividad", o que en una metodología además de establecer los pasos metodológicos y de investigación para la realización de un proyecto se enfatice la necesidad de la labor creativa.

I Programa de materia de la Licenciatura en Diseño Gráfico, Universidad de Sonora, 2009. Documento de circulación interna.
Es posible que todos los maestros por la disciplina que desempeñamos tratemos de alguna u otra manera de introducir este tipo de actividades dentro de nuestras asignaturas, pero aquí la propuesta intenta formalizar y estructurar el fomento de la creatividad en cada materia de manera que sepamos que el ejercicio creativo es constante en cada una de las clases impartidas y semestre tras semestre.

Un punto importante dentro de esta propuesta es el convocar reuniones de academia o por áreas para que entre maestros se logren acuerdos de cómo se manejarán estas unidades y por supuesto las que dicta el propio programa de clase.

Estas reuniones pueden ser realizadas al iniciar y al terminar el semestre. De esta forma los maestros además de llegar a acuerdos acerca de qué es lo que se impartirá en cada materia, al finalizar el semestre podrán compartir sus experiencias y observaciones, y así retroalimentarse unos a otros.

Otro punto a proponer es que al iniciar o finalizar el semestre los maestros lleven un curso de creatividad que impartan dentro del departamento, o que se convoquen a actividades creativas para los propios maestros, de tal forma que estos estarán estimulados también dentro de esta área y les será más sencillo dirigir a los estudiantes.

Tratar de promover la participación de los estudiantes en convocatorias externas a la universidad, ya sea nacionales o internacionales, para que esto los estimule y fomente la participación y el crecimiento como diseñadores creativos.

Por último, la difusión del trabajo de los estudiantes es muy importante, pero no solo difundirlo dentro de la escuela sino extender esta difusión en áreas o espacios públicos en los que la ciudad en general pueda participar en el enriquecimiento de la labor de los estudiantes. Es decir, participar como observadores e incluso interactuar con los trabajos de los muchachos de alguna manera o bien quizás tener acceso a dejar comentarios en algún 
buzón de notas en el cual los estudiantes puedan recibir retroalimentación no solo por parte del personal académico o de los otros estudiantes sino también del exterior.

Si se hiciera metódicamente estos pasos durante una generación completa se podría volver a realizar el estudio de evaluación de la creatividad con el instrumento EMUC o incluso implementar algunos otros instrumentos de evaluación de la creatividad y distinguir si hubo cambios con respecto a los resultados anteriores.

\section{Referencias bibliográficas}

Esteve, F. (2008). Análisis del estado de la creatividad de los estudiantes universitarios. Recuperado de http://www. increa.uji.es/arxius/publicacionesincrea//24.pdf

Frascara, J. (2004). Diseño Gráfico para la gente. Buenos Aires: Infinito.

Sánchez, P., García A., \& Valdés, A. (2009). Validez y confiabilidad de un instrumento para medir la creatividad en adolescentes. Revista Iberoamericana de Educación, 50 (6), 2-12. Recuperado de http://www.rieoei.org/ deloslectores/3014Escobedo.pdf

Sandoval, P. (2013). Un estudio sobre la creatividad de los estudiantes de Diseño Gráfico. Hermosillo: Universidad de Sonora.

Ziegler, M. (2000). Creatividad, aula y arte. Revista de Educación, 15. Recuperado de http://educar.jalisco.gob.mx/l5//5Ziegle. html 


\section{Estrategia didáctica basada}

en el aprendizaje lúdico

\section{de anatomía tipográfica}

Cynthia Lizette Hurtado Espinosa, Irma Lucía Gutiérrez Cruz, Eva Guadalupe Osuna Ruiz, Lourdes Anette Orozco Guzmán

\section{Introducción}

Es deber del docente la creación de nuevos métodos de enseñanza, que ayuden a la mejora del aprendizaje de los estudiantes, y en el caso de un Diseñador Gráfico, es imprescindible que utilice un vocabulario pertinente a su profesión.

Ya que la anatomía tipográfica es un tema con muchos términos y de difícil memorización, se propone el uso de una técnica didáctica divertida y lúdica que ayude a recordar más fácilmente todas las partes de la letra, y que además utilice sinónimos de acuerdo a diversos autores.

\section{El aprendizaje de la anatomía tipográfica}

En la licenciatura de Diseño para la Comunicación Gráfica del Centro Universitario de Arte, Arquitectura y Diseño (CUAAD) de la Universidad de Guadalajara, se estudia el tema de la tipografía a lo largo de la formación académica sin ser una materia obligatoria. Un aspecto, que gradualmente se les va olvidando a los estudiantes, es el aprendizaje de las partes de la letra, es decir, de la anatomía tipográfica.

Para poder corroborar que los estudiantes no recuerdan algunas partes específicas de la letra, se realizaron encuestas a 18 alumnos y ex alumnos de la carrera que consistía en presentarles varias imágenes que señalaban una parte distinta de las letras seleccionadas, y ellos deberían escribir el concepto correspondiente; los resultados fueron los siguientes: 


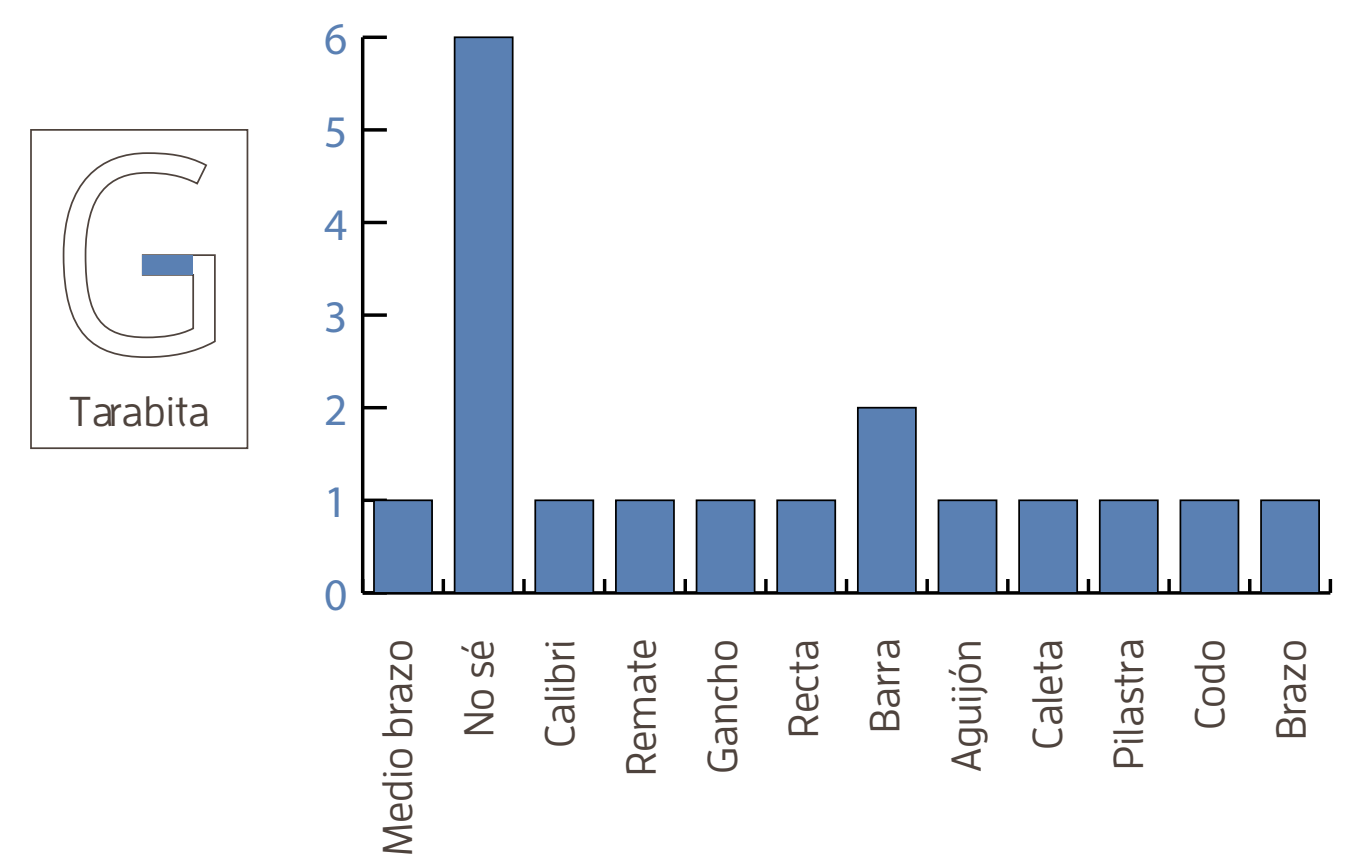

Figura I. Resultado de la encuesta sobre Tarabita.

Respecto alatarabita, todas las respuestasfueron incorrectas, lo único que se puede destacar es que seis de los encuestados respondieron sinceramente que no sabían y los demás intentaron resolver la pregunta.

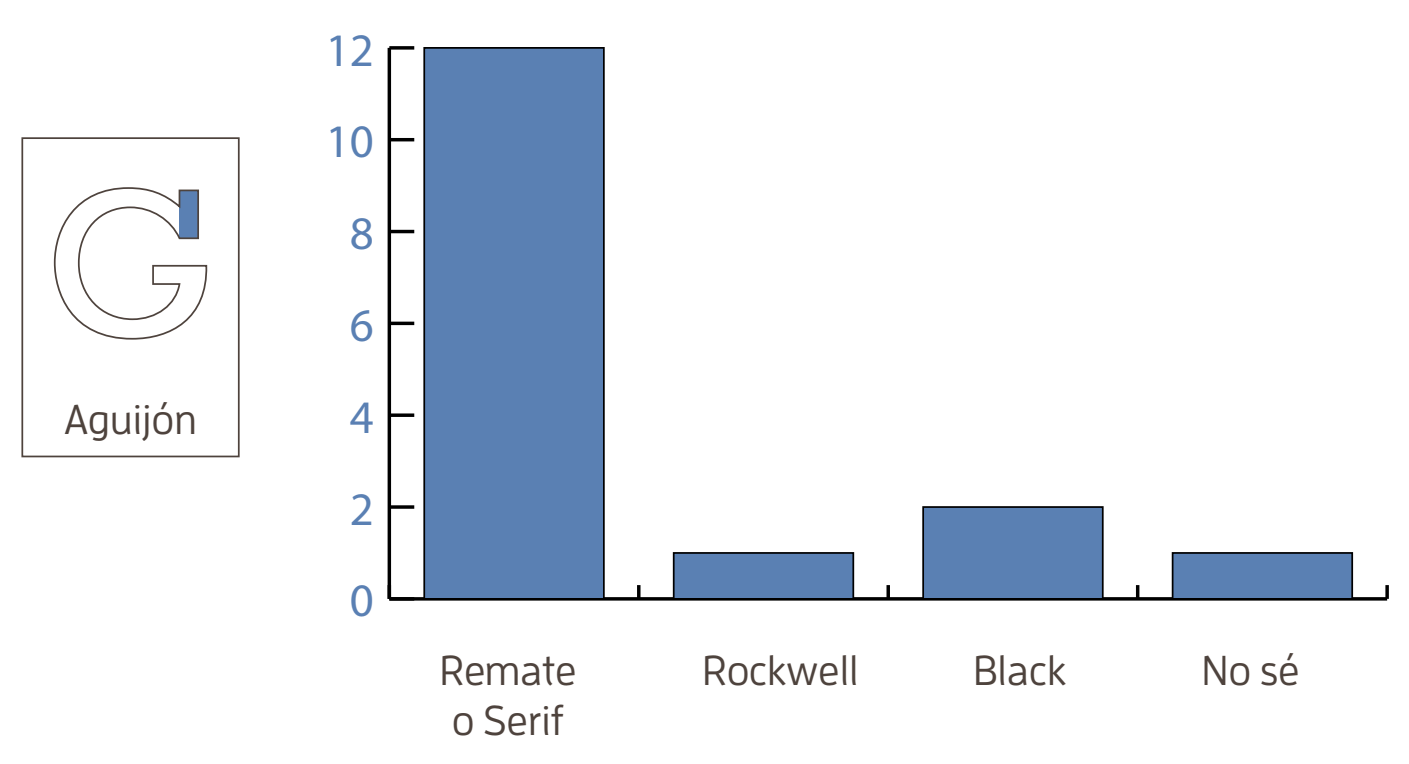

Figura 2. Resultado de la encuesta sobre Aguijón.
Respecto al aguijón, 12 respondieron de manera genérica que es un remate o serif aunque realmente el término más específico es aguiión; un dato curioso es que uno de los encuestados escribió el nombre de la fuente tipográfica.
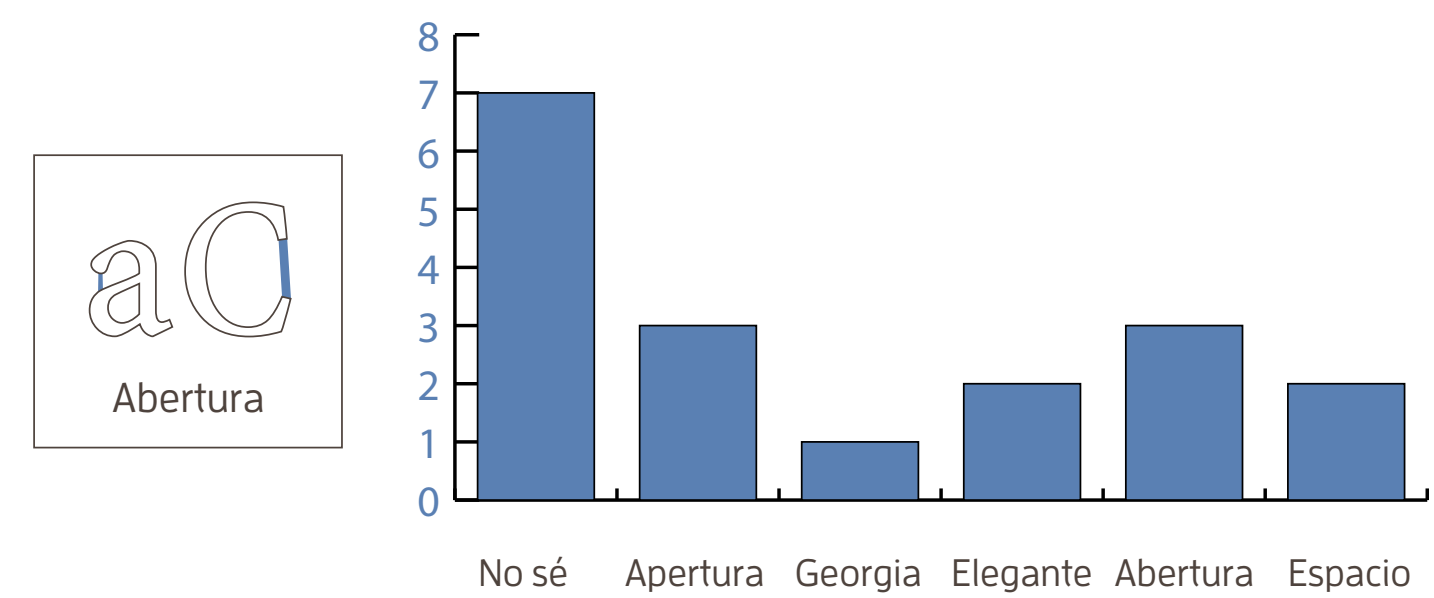

Figura 3. Resultado de la encuesta sobre Abertura.

En este punto, solamente tres atinaron a la respuesta y otros tres fonéticamente recordaron como era aunque se equivocaron con una $\mathrm{P}$ y dijeron apertura. Cabe mencionar que otro más entendió mal la pregunta y respondió que era la fuente tipográfica Georgia.

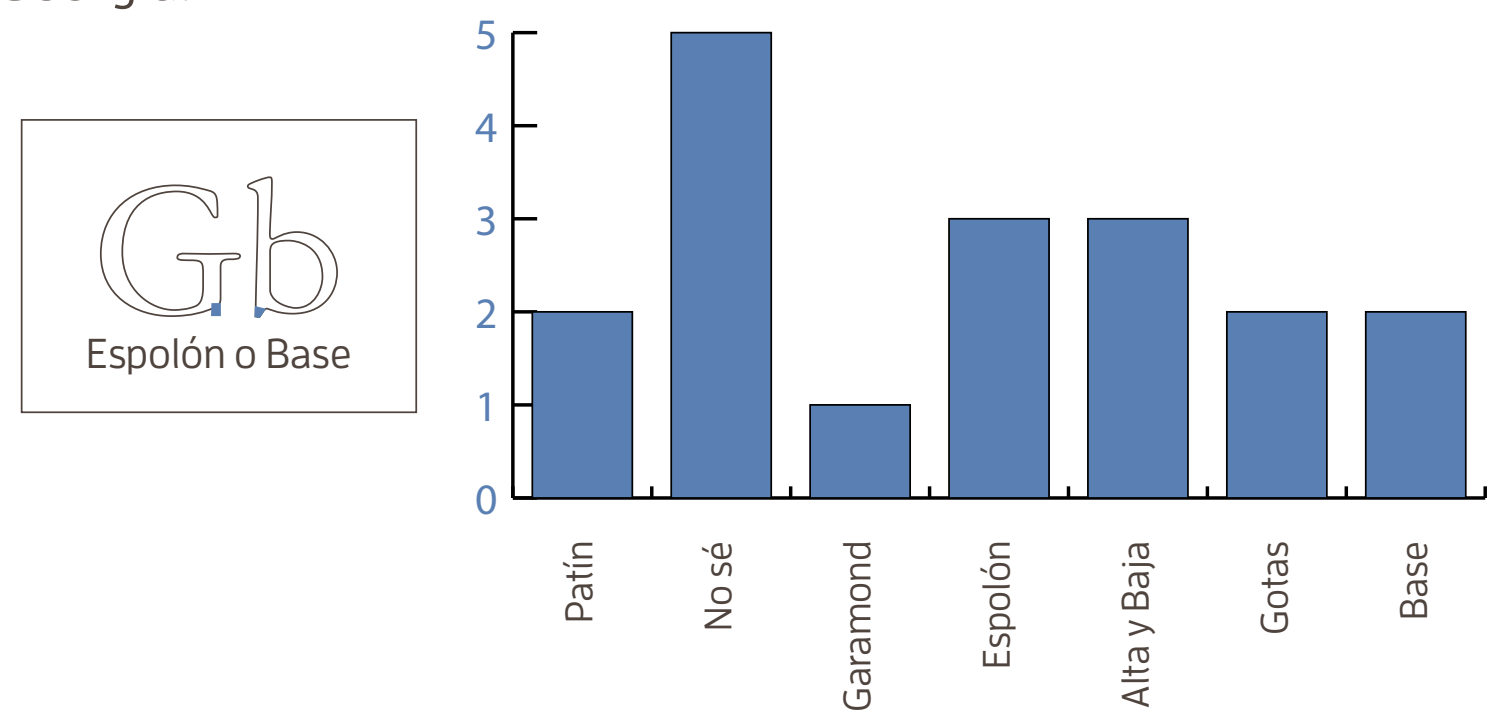

Figura 4. Resultado de la encuesta sobre Espolón o Base. 
En este caso solamente cinco recordaron el nombre, tres espolón y dos base, el resto no supieron a qué se refería, incluso tres coincidieron en hablar de alta y baja, siendo que nada de esto se había señalado.

Muchos de los conceptos fueron inventados por los propios alumnos y algunos otros con nombres similares, y otros completamente distintos a lo que realmente debería de ser.

Estas equivocaciones se argumentan de diferentes maneras, y una de ellas tiene que ver con la teoría del procesamiento humano de información, en donde López (200I, p. 17) menciona que:

Los teóricos del PH postulan que los humanos somos básicamente procesadores de información simbólica. De acuerdo con esta teoría, desde edades muy tempranas los humanos somos capaces de crear representaciones conceptuales que forman la base de nuestros procesos mentales posteriores [...] Estos esquemas de conocimiento son los que posteriormente nos permiten clasificar, reconocer y obtener significados de nuestro medio ambiente. Sin embargo, conforme nos vamos desarrollando a lo largo de nuestras vidas, el proceso de la formación de estas representaciones mentales está frecuentemente sujeta a errores.

Es por eso que en el transcurso de la carrera, hay algunos conceptos que se van confundiendo con otros, y la asimilación del conocimiento nuevo con el previo puede crear confusiones o reforzar lo que se está aprendiendo. Es cuando se debe de realizar alguna acción o estrategia para que la memoria a corto plazo se refuerce y se convierta en memoria a largo plazo, como en el modelo de cajas de almacenamiento y manipulación de información de Atkinson y Shiffrin en donde existe un decaimiento de la información cuando no se utiliza. Hoy ya no es necesaria, pero como en el caso de la anatomía tipográfica es útil durante toda la vida del diseñador gráfico para hablar con vocablos propios de la disciplina, se debe almacenar la información en la memoria a largo plazo y recuperarla en la memoria a corto plazo.

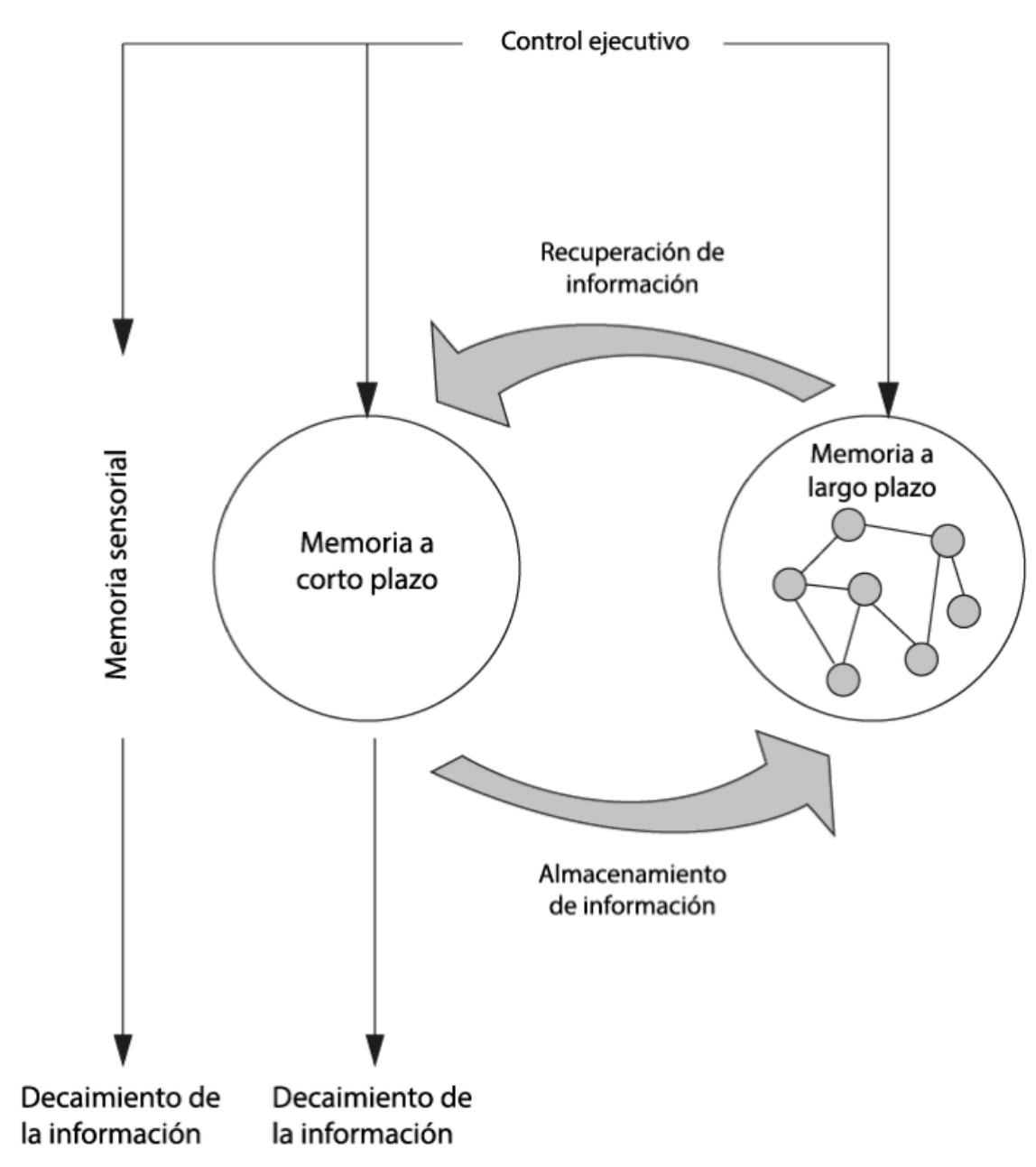

Figura 5. Modelo de cajas de almacenamiento y manipulación de información (Atkinson y Shiffrin, 1971).

Por lo tanto, cuando se habla de memorizar, Rajadell y Medina (2009, p. 102) dicen que se trata de "fijar metódicamente en la memoria un concepto o idea propuesto por una persona normalmente ajena", de tal manera que se ha buscado que de una forma metódica y a través del juego se memoricen las partes de la letra, utilizando una lotería tipográfica. 


\section{La lotería tipográfica}

Pensando en que una lotería tipográfica ayudará a la memorización de las partes de la letra, primero se hizo una investigación teórica sobretodoslosconceptos relacionados conla anatomíatipográfica, de tal manera que obtuvieron conceptos de los siguientes autores:

- Timothy Samara, Diseñador gráfico y profesor con una trayectoria de más de 20 años dedicada al Branding y el diseño de información.

- Hambrose Harrys, quién es un teórico de la tipografía, utiliza diferentes términos para distinguir las partes del cuerpo de la letra.

- Montesinos y Hurtuna, Montesinos es doctor en ingeniería del diseño de la Universidad politécnica de Valencia, es director de la editorial valenciana Campgráfic y ha trabajado en conjunto con Hurtuna.

Con el enfoque de cada uno de ellos, se realizó un análisis de los diferentes conceptos que utilizan para nombrar las partes de la letra, de tal manera que en cada carta de la lotería tipográfica se muestran todos los nombres referentes a la misma.

Finalmente se eligieron 45 conceptos por considerarlos los más importantes, se realizó una exploración en cuanto a diseño para saber cuál podría ser el más adecuado, y el estilo final que se utilizó fue de pizarrón verde, haciendo ajustes en las líneas de las letras para que pareciera que estaban dibujadas con gis (Ver Figura 6).

Se consideró necesario hablar no solamente de anatomía tipográfica, sino incluir algunos otros conceptos que tienen que ver con su estructura, por ejemplo, de la línea base la altura de $X$ la altura de las ascendentes y altura de las descendentes, que caracterizan a las fuentes tipográficas en cuanto a su proporción (Ver Figura 7).

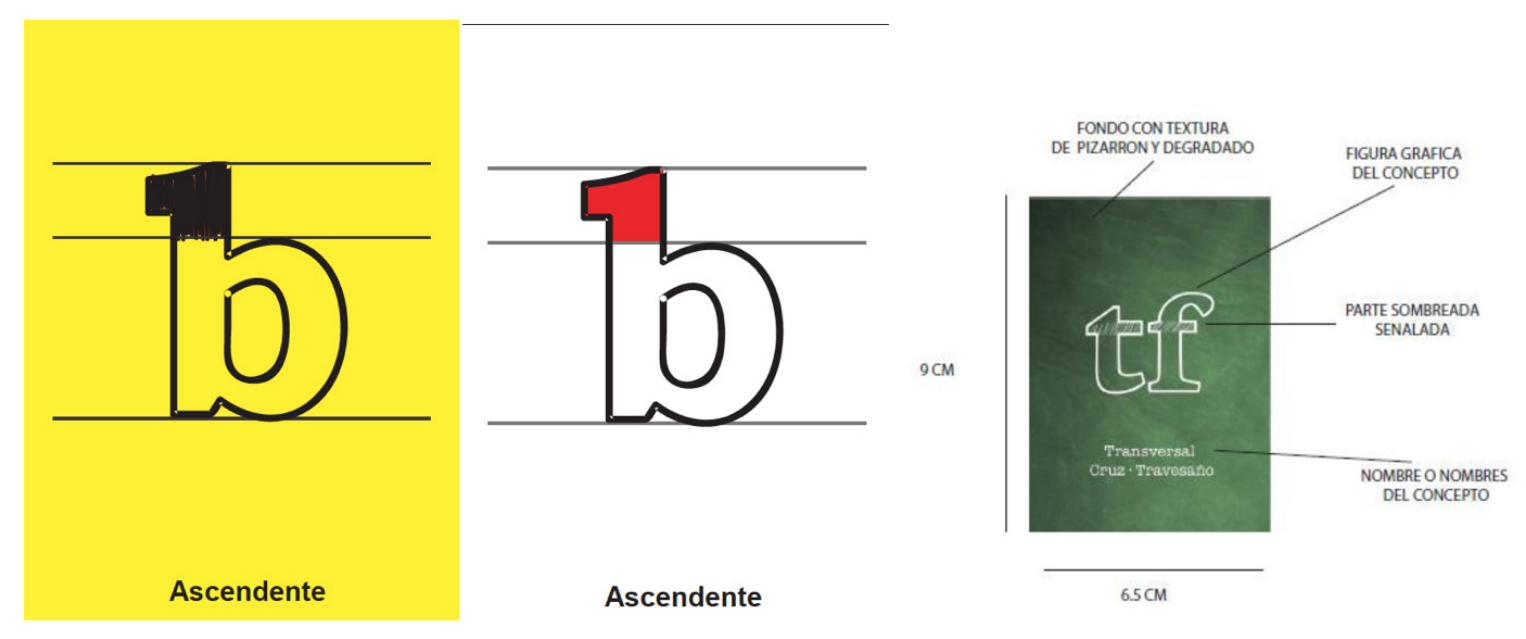

Figura 6. Exploración de estilos para las cartas.

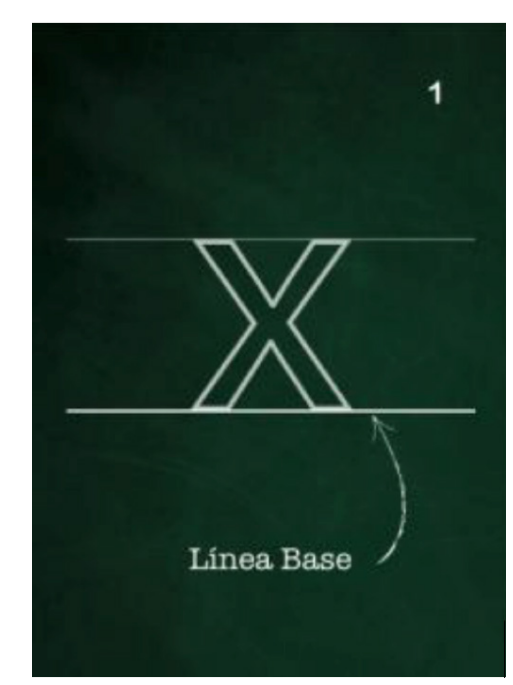

Figura 7. Carta representativa de la línea base.

Dependiendo de cada concepto se representó de diferente manera, por ejemplo en el caso del trazo se señaló la forma de la letra, pero en el caso del asta o fuste, lo que se señaló fue la parte correspondiente, simulando que se rellena esa parte con gis (Ver Figura 8). 

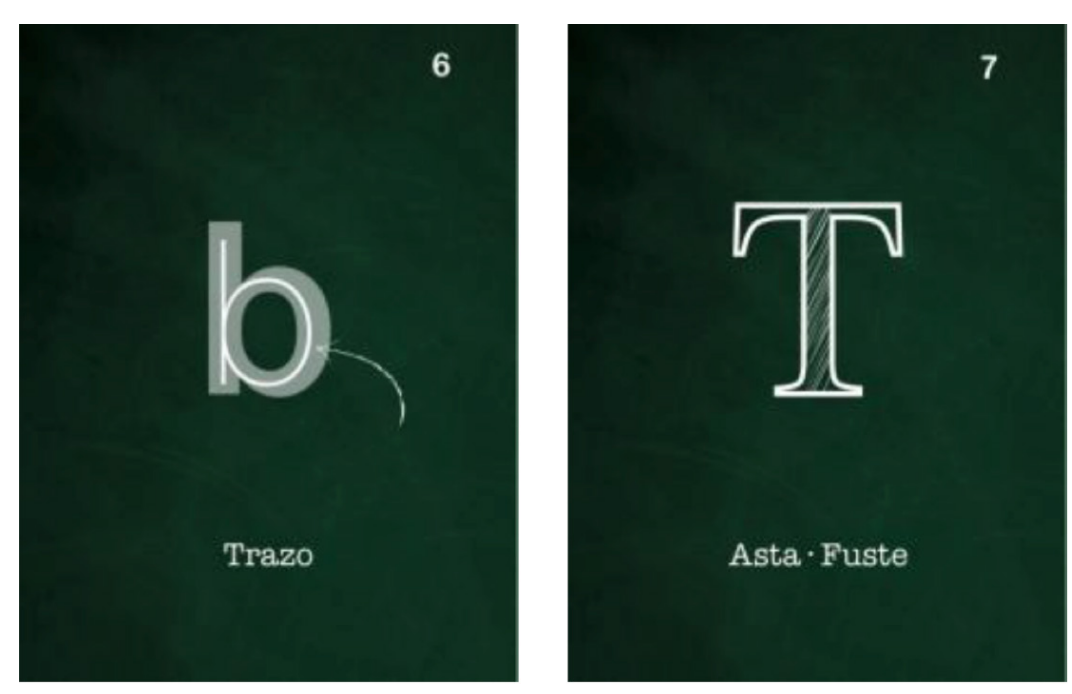

Figura 8. Carta representativa del trazo y carta representativa del asta o fuste.

\section{Evaluación de la lotería}

Para comprobar que la lotería ayuda a memorizar o a aprender las diferentes partes de la letra, se realizaron dos pruebas, una al inicio del juego, llamada prueba diagnóstico y otra al final del juego llamada prueba de comprobación. Se jugó a la lotería con un grupo de diseño editorial (quinto semestre) que ya habían pasado por el tema de anatomía tipográfica en la materia de diseño de marca, que se ve en segundo semestre.

Se consideraron las mismas letras que se utilizaron en la primer encuesta exploratoria, lo cual también ayudó a tener una referencia entre el proceso. La diferencia del reconocimiento de las partes antes y después es notoria. (Ver Figura 9).

Tomando como base las respuestas correctas e incorrectas de los alumnos en el texto anterior, se realizaron unas gráficas que comparan la respuesta de los estudiantes en bien, mal y no contestó de tal manera que se puede evidenciar gráficamente cuales fueron los resultados antes y después del juego.

(Ver Figura 10).

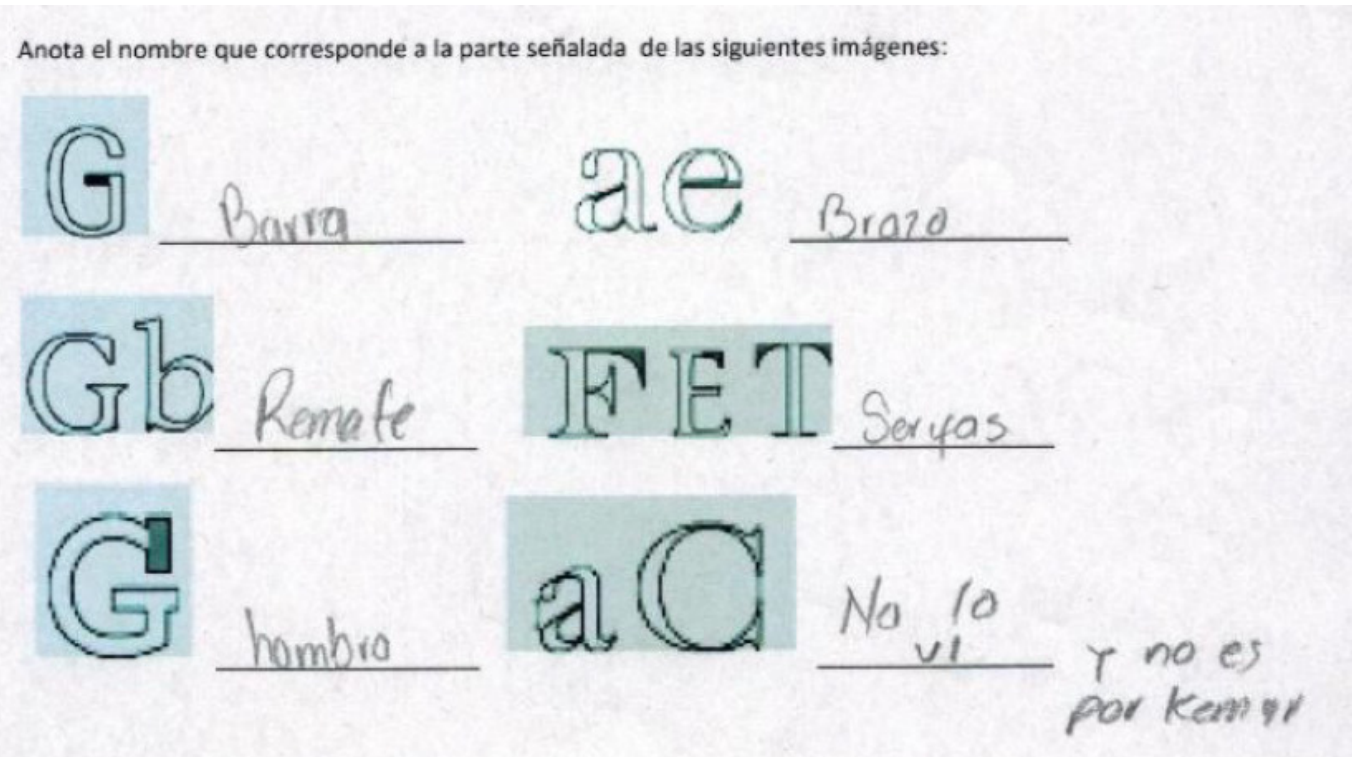

Anota el nombre que corresponde a la parte señalada de las siguientes imágenes:

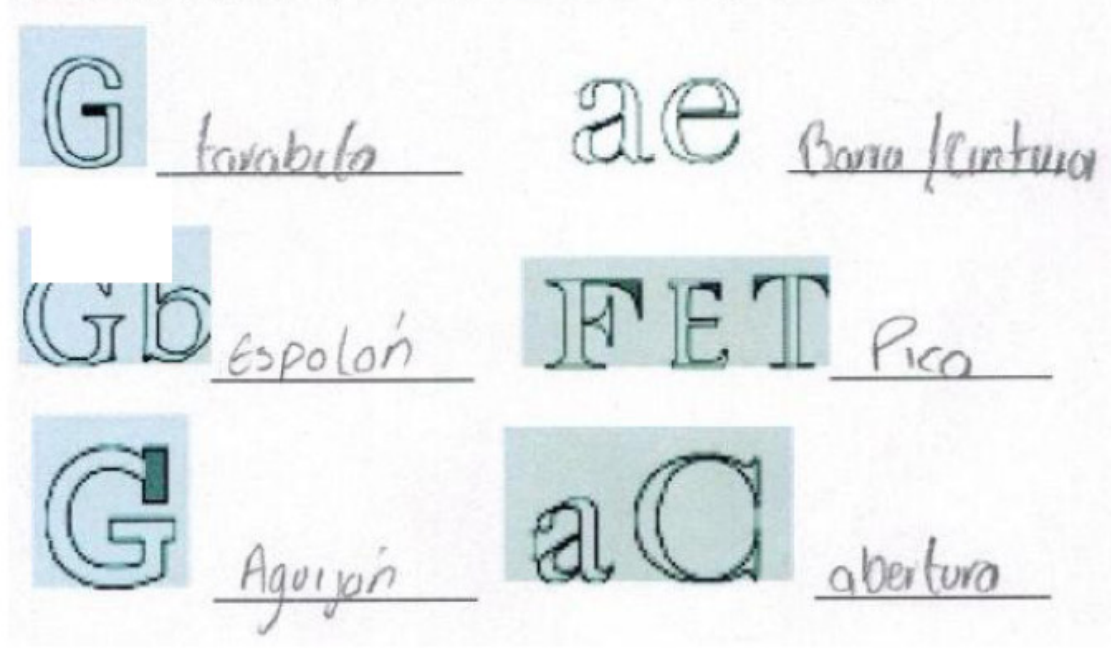

Figura 9. Ejemplo de la evaluación antes y después de la lotería. 


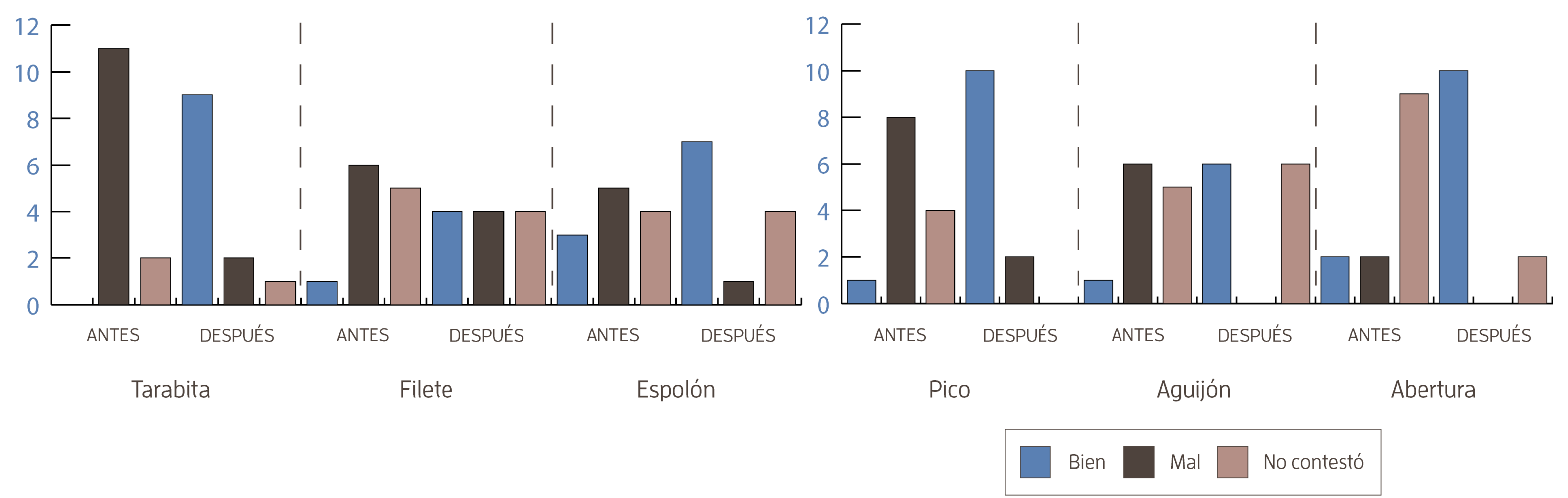

Figura IO. Gráfica que muestra los seis conceptos antes y después de jugar a la lotería.

\section{Conclusiones}

Encontrar una manera atractiva y divertida para los estudiantes ayuda a fortalecer la memorización de conceptos, en este caso con la lotería tipográfica aumentó en un 95\% las respuestas correctas de las partes de la letra.

Además de divertirse, los estudiantes adquieren conocimientos y también los diferentes conceptos que se refieren a una misma parte de la letra, de tal manera que su vocabulario propio de la disciplina del diseño gráfico se va fortaleciendo.

\section{Referencias bibliográficas}

Atkinson, R., \& Shiffrin, R. (I97I). The control of short-term memory. Scentific American, 224, pp. 82-90.

López, E. (200I). Los procesos cognitivos en la enseñanza aprendizaje. México: Trillas.

Rajadell, N., \& Medina, A. (2009). Didáctica. Formación básica para profesionales de la educación. Madrid: Universidad Nacional de Educación a Distancia. 


\section{Videotutoriales}

\section{para representación gráfica}

\author{
Rosa María Mendoza Robles, \\ Mario Yadir Rendón Sallard, \\ Fernando Saldaña Córdova
}

\section{Introducción}

El proyecto descrito a continuación propone aprovechar el acceso y la utilidad de las tecnologías de la información y la comunicación, al presentar al estudiante alternativas de autoestudio a través de tutoriales de diferentes técnicas de expresión gráfica en video, que apoyan el contenido académico de las materias que cursan en la carrera de Arquitectura. El Consejo de Financiamiento de la Educación Superior de Inglaterra ha identificado tres beneficios potenciales que el uso de la tecnología puede brindar a la educación -eficiencia, mejoramiento, y transformación-y resalta la necesidad de generar evidencia de la efectividad de la tecnología aplicada (Kirkwood y Price, 2014, p. 4). Asimismo, un informe publicado por el Copyright Clearance Center, Intelligent Television y New York University resalta la importancia de generar material video-gráfico original, que responda a las necesidades educativas específicas de cada materia e institución, y que además no incurra en violaciones de derechos de autor (Kaufman y Mohan, 2009).

El proceso en aulas en materias de expresión gráfica, en el momento de transmitir los sistemas de representación del dibujo sistemático en su nivel operativo, es decir, las herramientas que se utilizan para su representación, se enseñan por medio de ejercicios de una manera mayormente mecánica, luego de explicados los conceptos de geometría descriptiva y del espacio, así como las axonometrías. La realización de estos ejercicios de repetición está basada en el uso de instrumentos de precisión de dibujo: escalímetro, regla "T", escuadras, transportador, estilógrafos, tinta, etc. En estos ejercicios se califica limpieza, destreza, 
prolijidad y calidades de líneas, guías en sus letreros, y un sinfín de cualidades que se deben cumplir mínimamente en los ejercicios de estas láminas. En relación con el dibujo a mano alzada, implica la observación del objeto a dibujar, o a imitar, revisión de módulos, si acaso escantillones, medidas a ojo y realización de traducciones de emociones interpretadas y vaciadas al papel, iniciando por la percepción, en un proceso que Alva Noë define como "abordaje activo" (enactive approach), refiriéndose a la manera en que se logra el entendimiento sensorial-motor y conceptual por medio de la exploración y la indagación activas (Noë, 2004; p. 2).

La educación es un proceso de aprendizaje continuo y de permanente cambio (Burbules, 1999, p. 73), cuya formalización requiere una nueva postura ante actividades que ya se realizan cotidianamente (leer, escuchar, hablar, etc.), que permita enfocar, coordinar y dirigir estas actividades cotidianas hacia un objetivo de aprendizaje, en lo que Steve Woolgar identifica como "enculturación educativa": la orquestación de repertorios establecidos de interacción y comunicación humana (incluyendo el uso de videograbaciones) hacia el cumplimiento de objetivos específicos de un programa educativo (Woolgar, 2002, p. 158).

El uso de videos con fines de comunicación y entretenimiento se ha vuelto ubicuo en la sociedad moderna, pero con un creciente uso con fines educativos. El equipo que desarrolla este proyecto ha observado la proliferación informal del uso de imágenes digitales y video para suplementar las materias de expresión gráfica, que varía desde la simple captura fotográfica que hacen los estudiantes del pizarrón en lugar de anotar la tarea, a las instrucciones y tutoriales amateur subidos por estudiantes con los temas de la clase!

\section{Se puede consultar un video "Pasos Para Dibujar una}

Perspectiva" donde se explica la técnica de trazo perspectivo, disponible en https://www.youtube.com/watch?v= ijwpi8TZ7O\&list=UU9kYerdsHfmjrSsetHZ2esw
Dentro de iniciativas con fundamentación más académica encontramos la propuesta de Flipped Classroom (Clase Invertida), donde los estudiantes observan un video corto con los contenidos de un tema específico (explicación teórica) previamente en casa, dejando así el tiempo de la clase para dedicarlo a ejercicios de aplicación (proyectos), trabajos o debates que se realicen en grupo. Así, el tiempo que pasan en el aula se usa para desarrollar y evaluar las habilidades de los alumnos y recibir asesoría por parte del docente en los temas que haya dificultad. Algunas estrategias que se usan para invertir la clase ${ }^{2}$ son: a) Elaboración de videos propios, b) Usar videos o materiales de otros, c) Incluir preguntas en diferentes secciones del video y d) Monitorear y dar seguimiento a cada estudiante. Las estadísticas ${ }^{3}$ muestran que de 200 profesores que han usado el sistema de Clase Invertida, un $85 \%$ reportan mejora en la comprensión de los temas por parte de los alumnos, un 30\% están mejor conectados con sus alumnos y un $25 \%$ utiliza el tiempo de clase para profundizar en cada tema.

Lo que aquí se presenta no es un salón invertido, es un punto intermedio entre los dos anteriores, una videoteca de tutoriales de la que se dispondrá en línea y cuyo objetivo principal es apoyar en primera instancia a los estudiantes de los programas de Arquitectura y Diseño Gráfico de la Universidad de Sonora, siguiendo los contenidos de sus planes de estudio, aunque no se limita a ellos. Con la publicación abierta en línea en realidad se podría tener un alcance no sólo hacia dentro de la Universidad, sino más allá de sus fronteras, e independiente de si el usuario es estudiante, un profesionista, un artista o un simple interesado en el tema.

2 http://www.theflippedclassroom.es/infografico-que-es-flipped-classroom/, consultado el 19 de mayo de 2015.

3 http://www.shopia.org/flipped-classroom/flipped-results, consultado el 19 de mayo de 2015. 


\section{MATERIALES Y MÉTODOS Diagnóstico}

En la primera etapa se revisaron alrededor de 200 ligas de videotutoriales que se encuentran actualmente en la red, de las cuales se hicieron las siguientes observaciones. De los resultados de la búsqueda de videos con técnicas de expresión gráfica arquitectónica se distinguen los siguientes grupos:

I. Con un enfoque hacia el dibujo artístico, un 40\% aproximadamente.

2. Con un enfoque hacia la teoría de color y técnicas básicas un 40\% aproximadamente.

3. Con enfoque hacia la representación arquitectónica un $20 \%$ aproximadamente.

De estos últimos se registró lo siguiente:

I. Los video-tutoriales de expresión arquitectónica de nivel profesional se encuentran únicamente en inglés.

2. Los videos de técnicas de expresión arquitectónica en español son subidos a la red por iniciativa de los alumnos principalmente.

3. Hay muy pocos videos en español que surjan de una planeación didáctica, de éstos, la mayoría son iniciativas únicas sin secuencia, y con problemas de edición y producción.

4. No se encontró ninguna serie de videos que estén enfocados a apoyo de un plan de estudios: con una secuencia lógica, ni un guión predeterminado, solo ediciones amateur, principalmente de estudiantes.

Las técnicas que se indagaron fueron: tinta, lápiz de color, y marcadores. Las búsquedas se hicieron a través de los sitios de Bing, Google y Youtube, utilizando las siguientes palabras clave: "técnica de expresión gráfica", "video-tutorial", "how to illustrate", "prismacolor", "lápiz de color", "plumones, marcadores", "tinta", "dibujo técnico arquitectónico", "técnicas de ambientación", y "técnicas de ilustración". Además, se hicieron búsquedas adicionales en sitios conocidos especializados en video, introduciendo el nombre de la técnica únicamente en español.

La búsqueda se enfocó a videos en español no solo por el interés de producir videotutoriales en nuestro idioma, sino por el perfil del estudiante que llega al Departamento de Arquitectura y Diseño de la Universidad de Sonora: más de la mitad de los estudiantes no alcanza el nivel suficiente de inglés ${ }^{4}$ para entender un video-tutorial que no cuente con subtítulos. Además, la Education First English Proficiency Index -dedicada a medir el nivel de inglés para empleados y empleadores internacionalmente- le otorga a México una clasificación de 49.83 (nivel bajo) de inglés, siendo el sexto país en el ranking de 14 evaluados en América Latina, y ocupando en lugar 39 de 63 países evaluados 5 .

\section{Proceso de Grabación}

En la elaboración de los videotutoriales y el sitio web, se aplicaron principios del uso de la tecnología para generar contenido innovador, tomando en cuenta las necesidades de alumnos y docentes, así como los lineamientos sugeridos por la evidencia científica (Price y Kirkwood, 20II), y sin dejar de lado las advertencias

4 Según información proporcionada por la Dirección de Servicios Escolares de la Universidad de Sonora, en 2012 el 51\% de los estudiantes del Departamento de Arquitectura y Diseño ingresaron con un nivel 3 o inferior de inglés. En el 2013 fue el $57 \%$ el que obtuvo dicho resultado. El nivel 3 se considera un nivel bajo de inglés, insuficiente para entender una conversación hablada a velocidad natural.

5 Información obtenida del portal http://www.ef.com.mx/epi/ spotlights/latin-america/mexico/, consultado el 19 de mayo de 2015. 
de estudios como el de Borges (2005) sobre la frustración del estudiante en línea y cómo evitarla. Borges señala dentro de las principales fuentes de frustración al tiempo del que dispone (o no) el estudiante: tomando esto en consideración se dividieron los videos de forma que ninguno tenga más de 5 minutos de duración, y se estructuraron de forma que primero hay un video de presentación del instructor, un video de introducción a la técnica, otro(s) realizando aplicaciones sencillas, y varios más explicando aplicaciones profesionalizantes. Otra de las fuentes de frustración del estudiante en línea que señala Borges es albergar expectativas irreales, lo cual prevenimos en el video de presentación incluyendo un saludo del instructor que además explica qué es lo que se va a observar en dicha serie de videos. Asimismo, al inicio de cada nuevo ejercicio se incluye una lista de los materiales que serán necesarios para ejecutarlos. De esta forma se espera publicar videos que sean amigables y efectivos.

Una vez determinada la necesidad de realizar videos originales en español, se elaboró un esquema de los contenidos de las diferentes secciones y técnicas por presentar, donde se definieron las siguientes etapas de trabajo (aunque no fueron necesariamente secuenciales):

I. Captura de técnicas manuales.

2. Captura de técnicas digitales.

3. Creación de biblioteca digital de video tutoriales (simultáneo a etapas I y 2).

4. Publicación en línea de biblioteca digital.

5. Publicación de libro con DVD de videos de alta resolución.

La didáctica utilizada en la formulación de losvideos responde a tres directivas principales: a) Descripción del medio (¿qué es?), b) Explicación de la técnica (¿cómo se usa?), y c) Ejercicios de aplicación de la técnica en documentos arquitectónicos: planta, alzado, perspectiva, vegetación, personas, etc.
Las grabaciones de la primera etapa se iniciaron únicamente con un esquema básico y sin un guión real, definiendo paso a paso las formas y contenidos que se grabarían. En el proceso de las primeras pruebas de grabación surgieron los siguientes aprendizajes:

Fue necesario estabilizar el equipo para que las tomas no brincaran, y en consecuencia se fabricaron soportes especiales (ver Figura I).

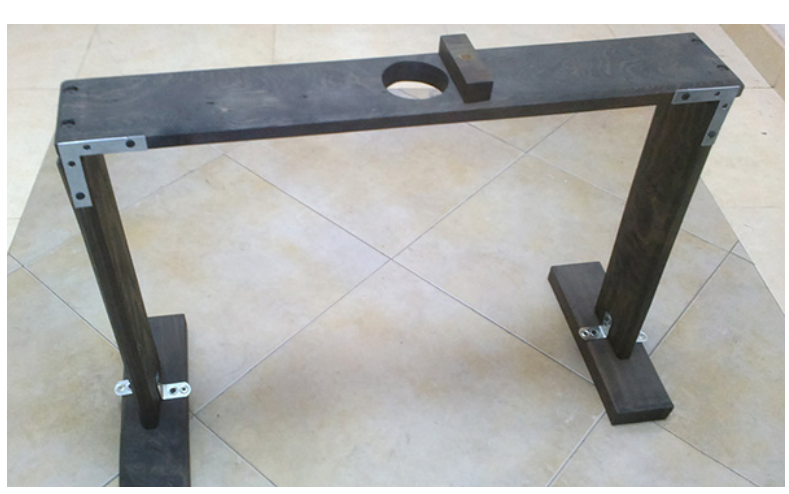

Figura I. Muestra del soporte especial.

Se descartaron ciertas cámaras que al probarlas no funcionaron. Cabe mencionar que este proyecto se ha realizado mayormente con recursos propios, por lo que se probó todo el equipo que se tenía disponible (ver Figura 2).

Figura 2. Pruebas fotográficas con distintas cámaras. 
Con las primeras pruebas de video, se decidió qué tipo de tomas (ángulos) y qué cámaras convenían más para una mejor calidad de video (ver Fig. 3)

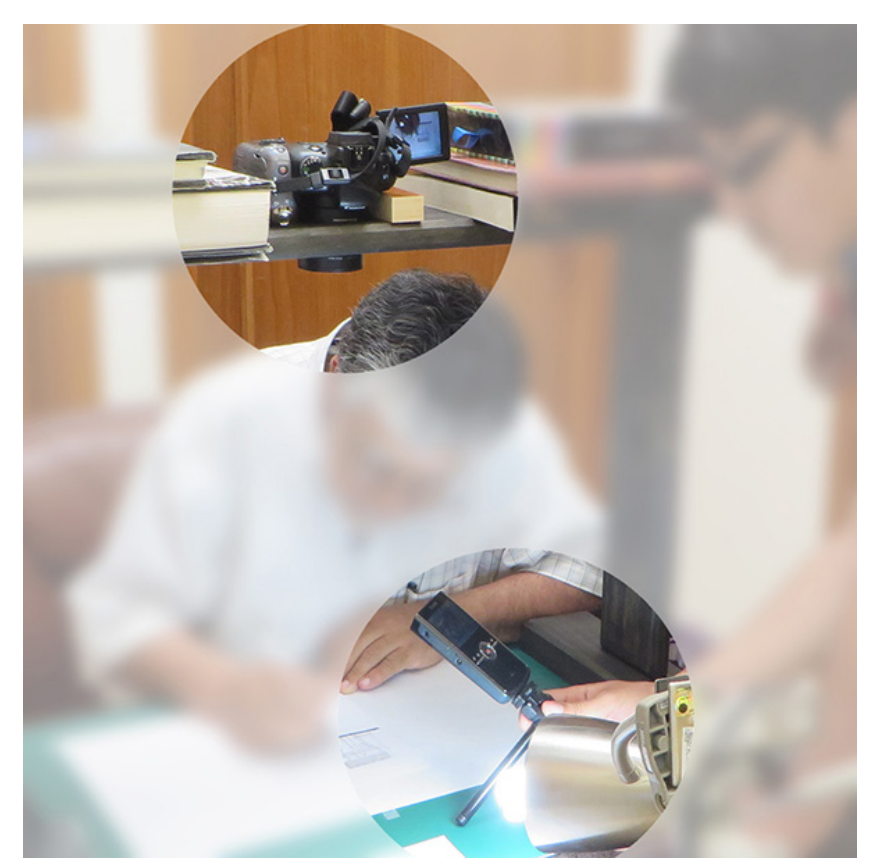

Figura 3. Detalle de cámaras.

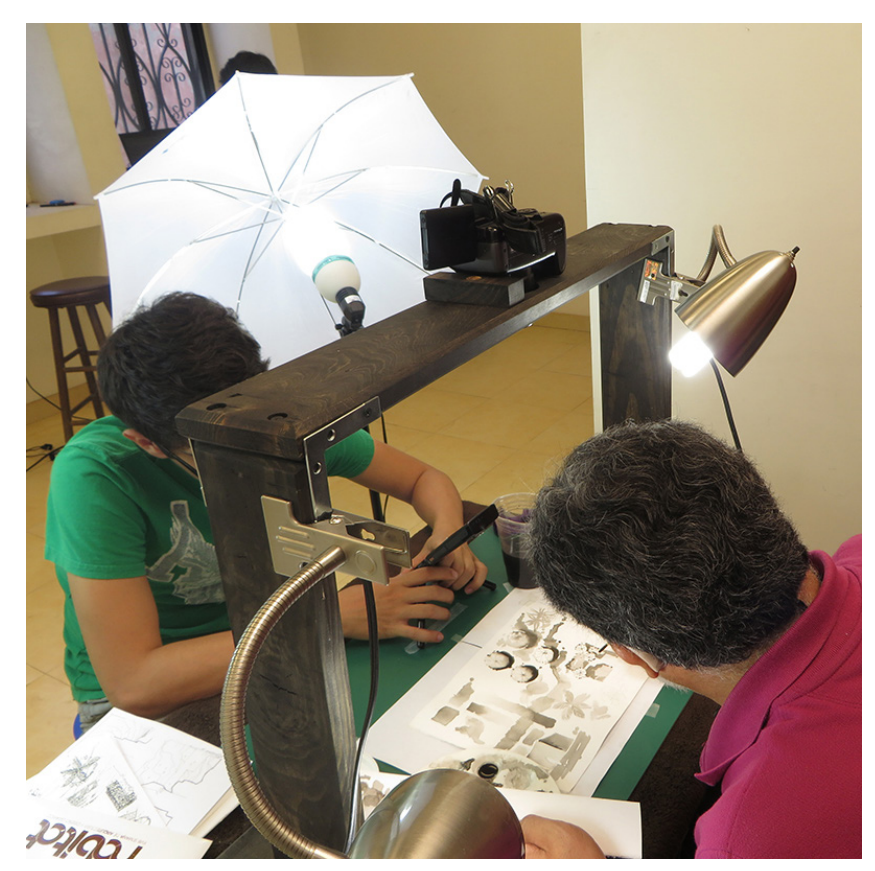

Figura 4. Prueba de iluminación.
La edición de los videos de esta etapa reforzó las directrices comentadas anteriormente, destacando los conceptos cuando son mencionados a través de letreros o acercamientos. Empleando las diferentes tomas (posición y ángulo de la cámara) se fueron seleccionando las partes que mejor explicaban la técnica $y_{\text {, }}$ en algunos casos, se aumentó la velocidad del video para una optimización del tiempo, ya que el objetivo es generar videos cortos que no excedan los 5 minutos. Cuando una técnica requiere más tiempo, el video se parte en dos o más partes. Además del equipo de docentes que realiza el proyecto, se contó con el apoyo de estudiantes prestadores de servicio social en la parte de edición y compilación de los videos.

El software utilizado para la edición de los videos fue Sony Vegas, que fue seleccionado por su facilidad de uso y permitió la integración de varias fuentes de video (en diferentes formatos), audio (narración del tutorial), imágenes de las técnicas (fotografías de detalle) y transiciones de textos.

En el periodo de edición se aprendió lo siguiente:

También se detectó que era necesario tener una mejor iluminación, por lo que se consiguió apoyo con otros profesores del departamento que contaban con dicho equipo (ver Fig. 4).

Asimismo, se creó un sistema de comunicación con el artista para poder parar la grabación cuando fuera necesario.
- Se vio la necesidad de aislar mejor el sonido captado por los equipos, así como la necesidad de grabar la narración por separado (usando una grabadora de voz), para facilitar su edición.

- Se hizo necesario un guión mucho más detallado, tanto para una mejor planeación de contenidos, como para lograr una edición más eficiente y por lo tanto mejores resultados.

- Fue necesario modificar el guión de forma que se utilice un papel por separado para cada elemento que se desarrolla y así lograr mejores tomas.

\section{Equipo utilizado}

El equipo de trabajo incluye a tres docentes del área de expresión de la Licenciatura en Arquitectura, apoyados por un proyecto de servicio social donde se contó con la participación de dos 
alumnos que apoyaron durante 8 meses y uno más integrado recientemente. Ninguno de los integrantes del equipo contaba con experiencia previa en producción y/o post-producción de este giro de video, lo cual ha implicado un espléndido proceso de aprendizaje. Asimismo, el equipo tecnológico con que se contó es limitado, lo cual se ha balanceado con creatividad e inventiva. En la Tabla I podemos observar el desglose del equipo e instalaciones utilizados.

Tabla I. Equipo utilizado.

\begin{tabular}{|c|c|}
\hline Equipo y Modelo & Uso \\
\hline $\begin{array}{l}\text { Cámara digital Canon } \\
\text { PowerShot SXIO IS }\end{array}$ & $\begin{array}{l}\text { Montada sobre un soporte de } \\
\text { madera para lograr tomas desde } \\
\text { arriba del área. }\end{array}$ \\
\hline $\begin{array}{l}\text { Cámara digital Kodak Zi8 } \\
\text { Cámara digital Canon } \\
\text { PowerShot SX280HS }\end{array}$ & $\begin{array}{l}\text { Montada en tripié para tomas de } \\
\text { detalle en primeros planos. }\end{array}$ \\
\hline Cámara de iPad 2 & $\begin{array}{l}\text { Para grabar el proceso de mezclado } \\
\text { de colores. }\end{array}$ \\
\hline $\begin{array}{l}\text { Soporte de madera (fabricado a } \\
\text { medida) }\end{array}$ & $\begin{array}{l}\text { Para tomas desde arriba del área de } \\
\text { trabajo. }\end{array}$ \\
\hline $\begin{array}{l}\text { Grabadora de audio digital Sony. } \\
\text { Micrófono de solapa. }\end{array}$ & Captura de audio. \\
\hline 2 lámparas de escritorio & $\begin{array}{l}\text { Colocadas en el soporte brindando } \\
\text { una iluminación lateral. }\end{array}$ \\
\hline $\begin{array}{l}2 \text { focos de } 300 \text { w con sombrillas } \\
\text { de proyección de luz }\end{array}$ & Iluminación directa. \\
\hline Tragaluz & $\begin{array}{l}\text { Se colocó el área de grabación } \\
\text { debajo de un tragaluz ( } 3 \text { metros de } \\
\text { separación) para captar la mayor } \\
\text { cantidad de luz natural posible, en } \\
\text { espacio del despacho Ateliori. }\end{array}$ \\
\hline
\end{tabular}

\begin{tabular}{|l|l|}
\hline $\begin{array}{l}\text { 3 memorias MicroSD, de 8GB } \\
\text { I disco duro externo de 2TB }\end{array}$ & $\begin{array}{l}\text { Almacenaje y respaldo de todo el } \\
\text { material de grabación y edición. }\end{array}$ \\
\hline I escáner HP, tamaño carta & $\begin{array}{l}\text { Para digitalización de los trabajos } \\
\text { realizados. }\end{array}$ \\
\hline 2 computadoras portátiles. & Para la edición de los videos. \\
\hline
\end{tabular}

\section{EVALUACIÓN}

Para poder evaluar la efectividad de esta nueva herramienta, se realizaron pruebas piloto de los tutoriales con dos grupos focales, a los cuales se les presentaron los videos, con la instrucción de seguir el tutorial tal y como lo harían en su casa en caso de buscar algún tutorial para cualquier tema. Se les proporcionaron lápices de colores y papel para la realización del ejercicio, y al finalizar contestaron una encuesta sobre el tutorial que realizaron.

Las pruebas se realizaron en el Centro de Cómputo de la Escuela de Arquitectura y Diseño. Para poder individualizar la reproducción de los videos, se proporcionaron audífonos a los estudiantes para que el sonido de unos no distrajera a los demás.

Como se mencionó, una vez ejecutados los tutoriales, todos los estudiantes respondieron una encuesta acerca de sus percepciones de la calidad de video y la facilidad de su uso. Dicha encuesta utilizó el software de encuestas SurveyMonkey para la elaboración y análisis de la misma, todo en línea.

\section{Ejecución y análisis de las pruebas}

El Grupo Focal A (GF-A) consistió de 8 participantes: 6 estudiantes de nivel medio y avanzado, así como de 2 recién egresados del Programa de Arquitectura (ver Fig. 5). Realizaron la primera prueba, a través de la observación de dos videos de introducción a la técnica, así como tres videos de aplicación: dos árboles y una palmera. Y se les solicitó que lo reprodujeran con el material proporcionado. 


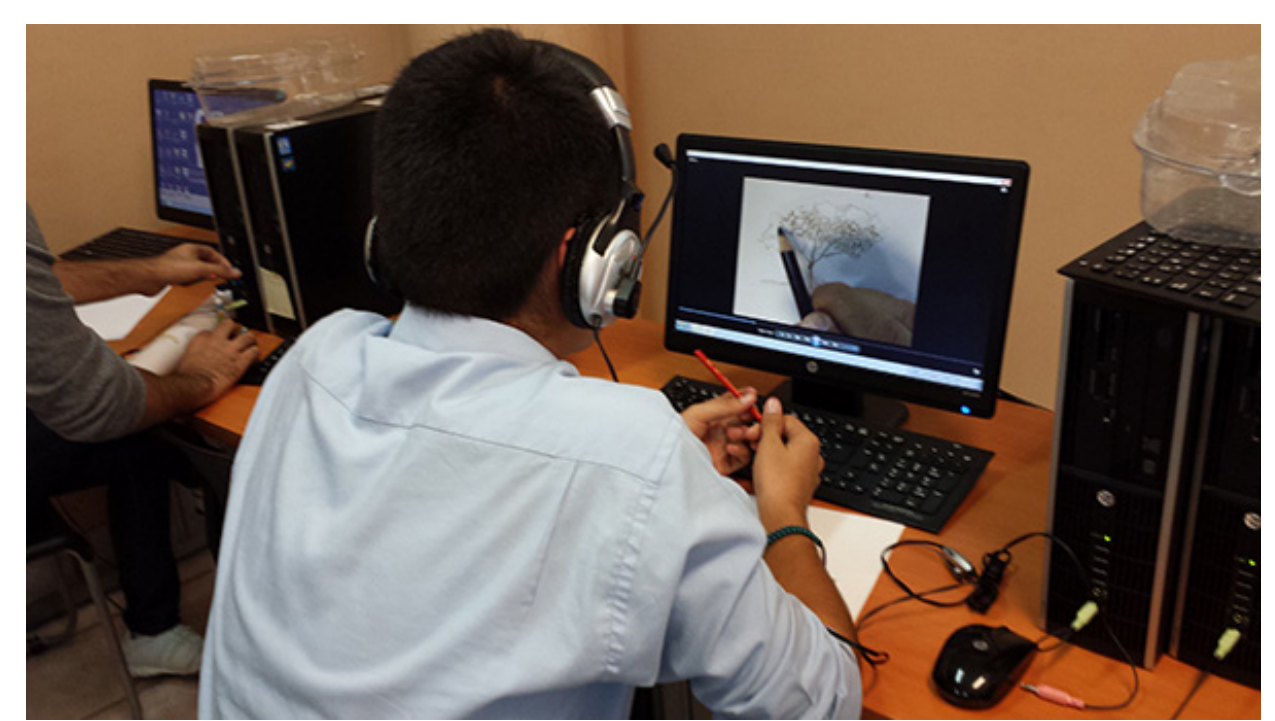

Figura 5. Aplicación a GF-A.

En la Tabla 2 se muestran los ejercicios del GF-A donde se observa un muy buen dominio de la técnica mostrada en el video. Sin embargo al no contar con un elemento de comparación previo a la aplicación del videotutorial, y considerando que se trataba de estudiantes de grados avanzados se decidió hacer una segunda aplicación de la prueba a estudiantes de semestres iniciales, que constituirán el Grupo Focal B (GF-B).

El GF-B estuvo compuesto por 13 participantes: once estudiantes de nivel básico de Arquitectura (primero y tercer semestre), uno de nivel medio (quinto semestre), además de un estudiante de nivel básico de Diseño Gráfico (Ver Fig. 6).

Al grupo GF-B, antes de ver los videos, se le solicitó que dibujaran un árbol y una palmera con los conocimientos que poseían hasta ese momento sobre representación. El objetivo fue documentar un punto de comparación visual y evaluar el grado de avance producto del tutorial. Igual que al grupo anterior, se les presentaron dos videos de introducción a la técnica, así como tres videos de aplicación: dos árboles y una palmera, y se les dio la misma instrucción de ver el tutorial y seguirlo tal y como lo harían en casa para aprender una técnica específica.

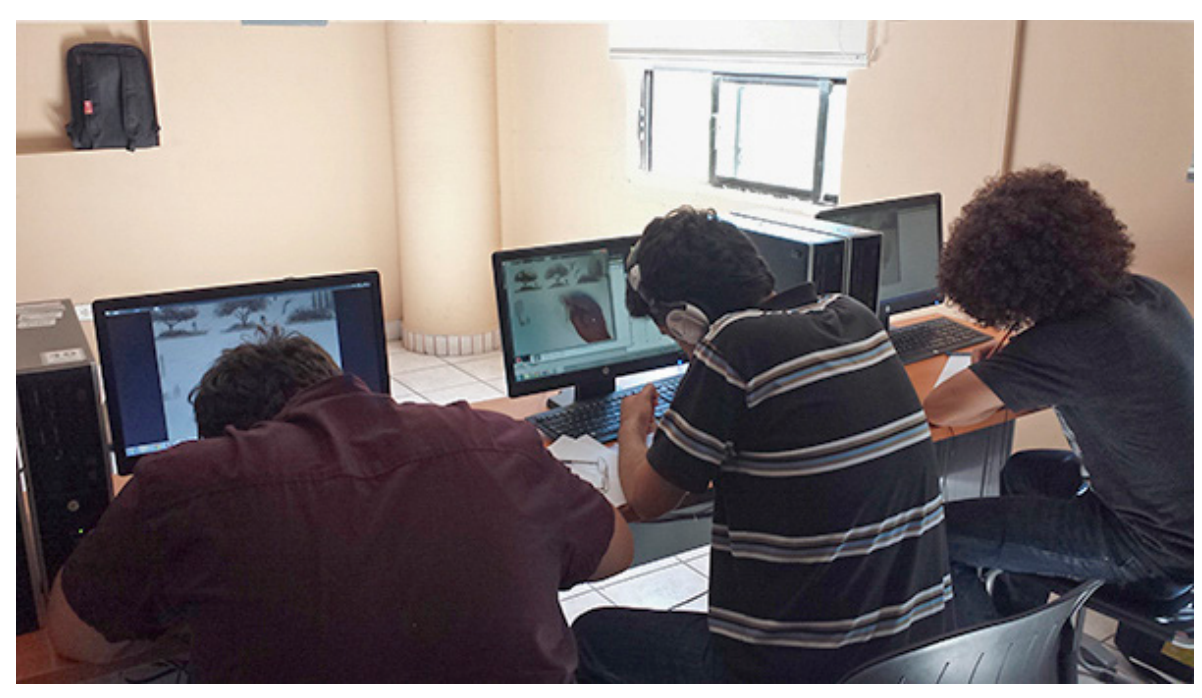

Figura 6. Aplicación a GF-B.

Contar con la referencia previa a la utilización del video hace evidente el impacto directo al producto de los estudiantes que se muestran en las comparativas de la Tabla 3 y la Tabla 4, en las siguientes páginas. Tanto en primer como tercer semestre, los estudiantes mostraron mejora en la estructura general de dibujo, así como en la aplicación en sí del lápiz de color.

Entre las opiniones recibidas por parte de los estudiantes al finalizar el ejercicio, destacó un comentario sobre algunos espacios sin sonido en el video, los cuales causaban inquietud al estudiante, ya que no podía identificar si era que estaba fallando el sonido del tutorial, o realmente así era el video. Para evitar esto en las secciones en silencio se incluyó música suave de fondo.

Otra estudiante hizo el siguiente comentario: "Ahora entiendo por qué los hacen como los hacen", refiriéndose a que antes nunca había podido dibujar correctamente un árbol para ambientación arquitectónica, lo que nos habla no sólo de comprensión de la técnica, sino del entendimiento de la representación. 
Tabla 2. Grupo Focal A (GF-A): Quinto y Noveno Semestre.

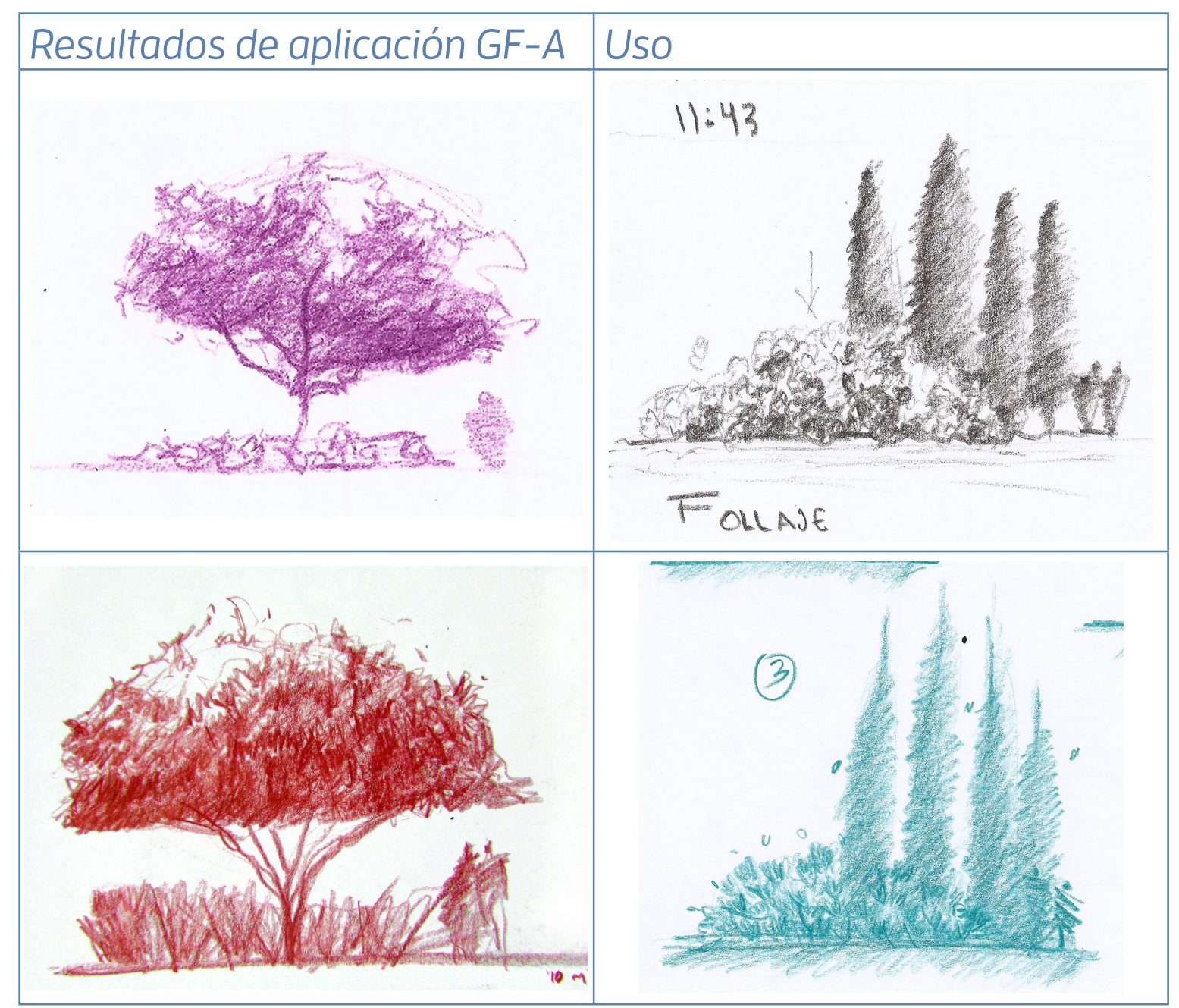

En el GF-B, que se componía de 13 estudiantes, el 61\% de los encuestados dijo utilizar video-tutoriales más de 4 veces en el semestre, con un enfoque principalmente académico, a diferencia del GF-A, donde la consulta de tutoriales era menor de 3 por semestre, aunque el enfoque coincidía como principalmente académico.

Del GF-B, en concordancia con su nivel de estudios, la gran mayoría tenía un nivel medio a bajo de conocimientos del tema que se explicaba (92\%). La mayoría de los participantes
Tabla 3. Grupo Focal B (GF-B): Primer Semestre.

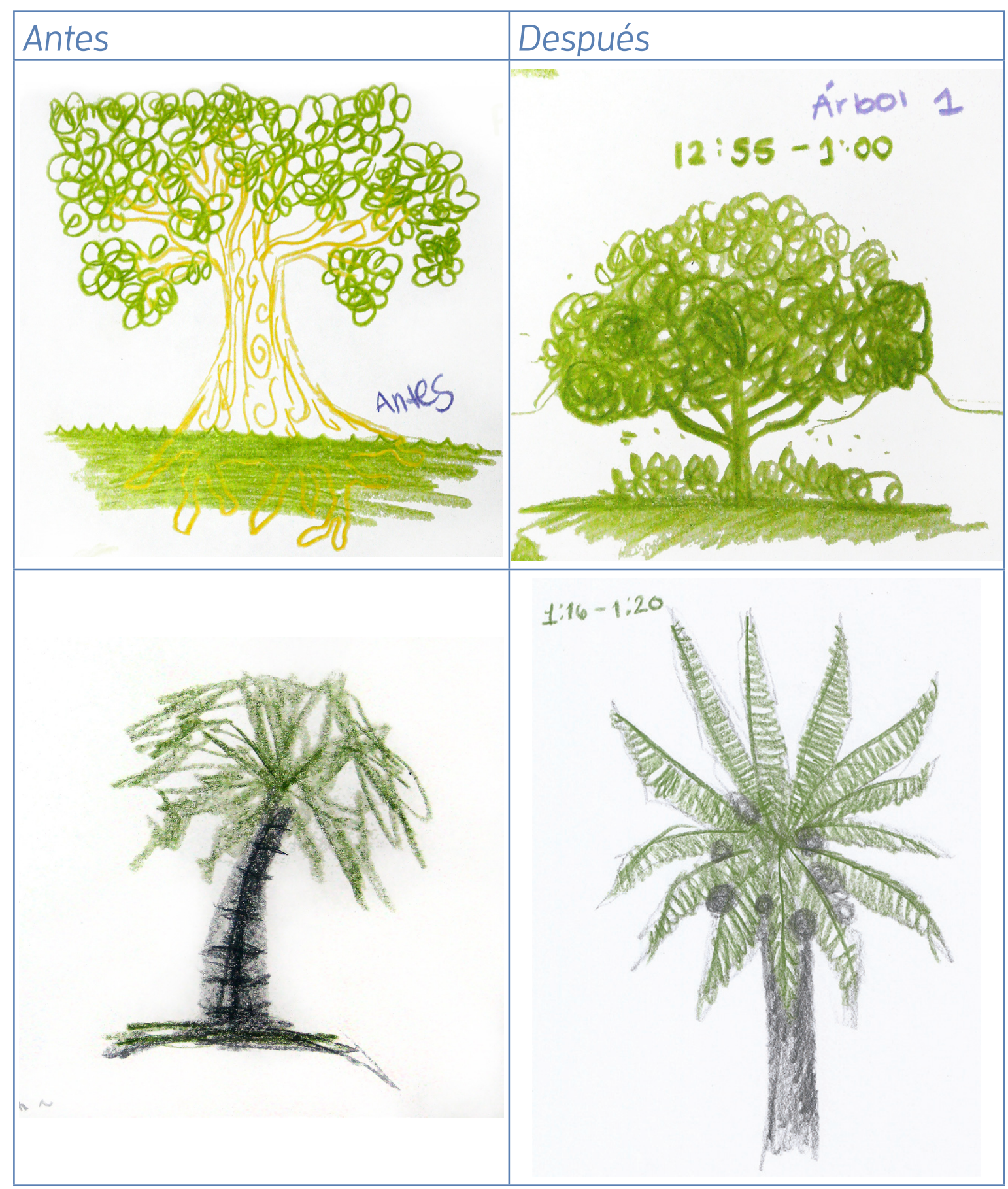

de este segundo grupo focal (69.23\%) consideraron que sí mejoró mucho la habilidad que les fue presentada en el ejercicio. Curiosamente, el GF-A de semestres avanzados, que presentó 


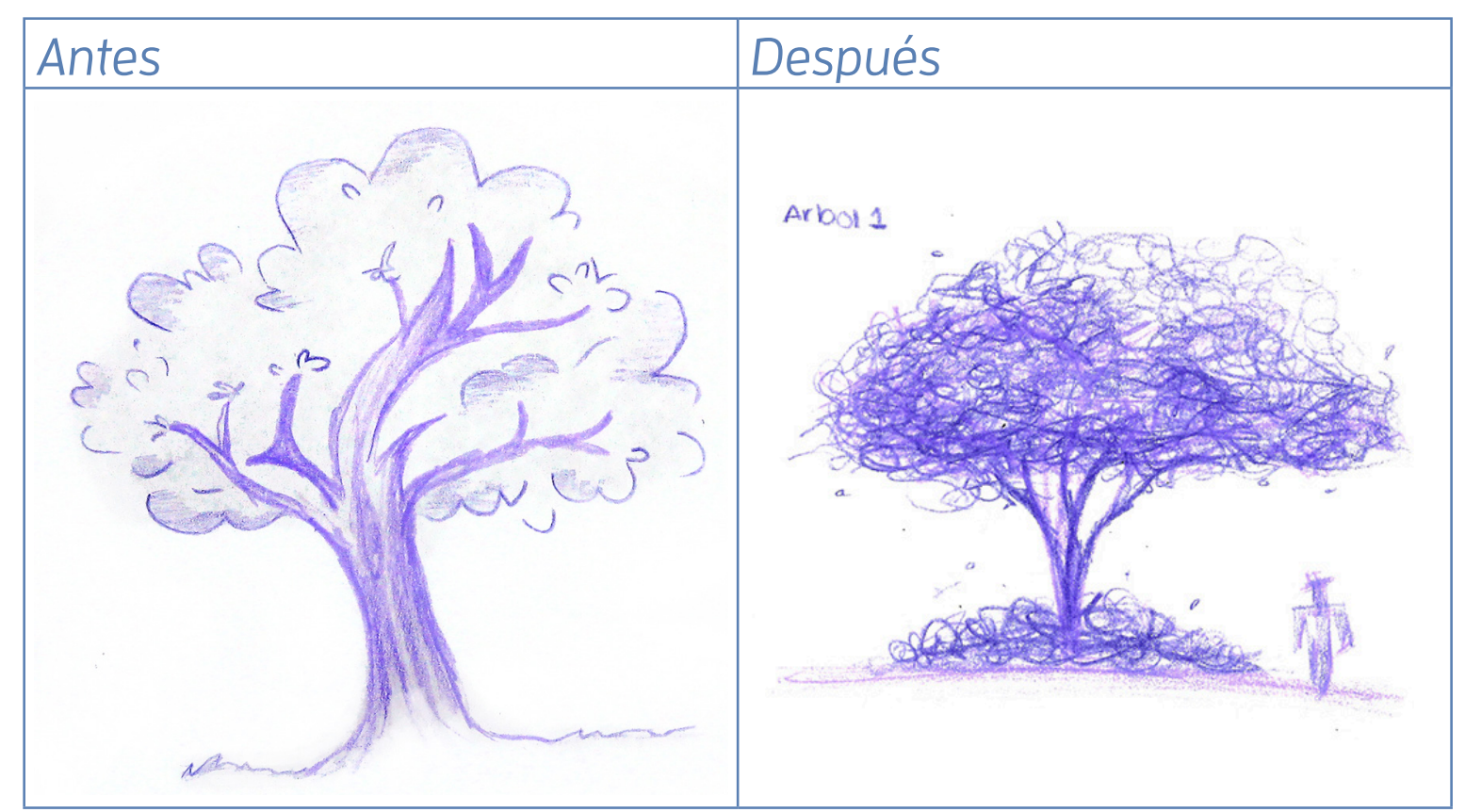

Tabla 4. Grupo Focal B (GF-B): Primer semestre Diseño Gráfico y Tercer semestre Arquitectura

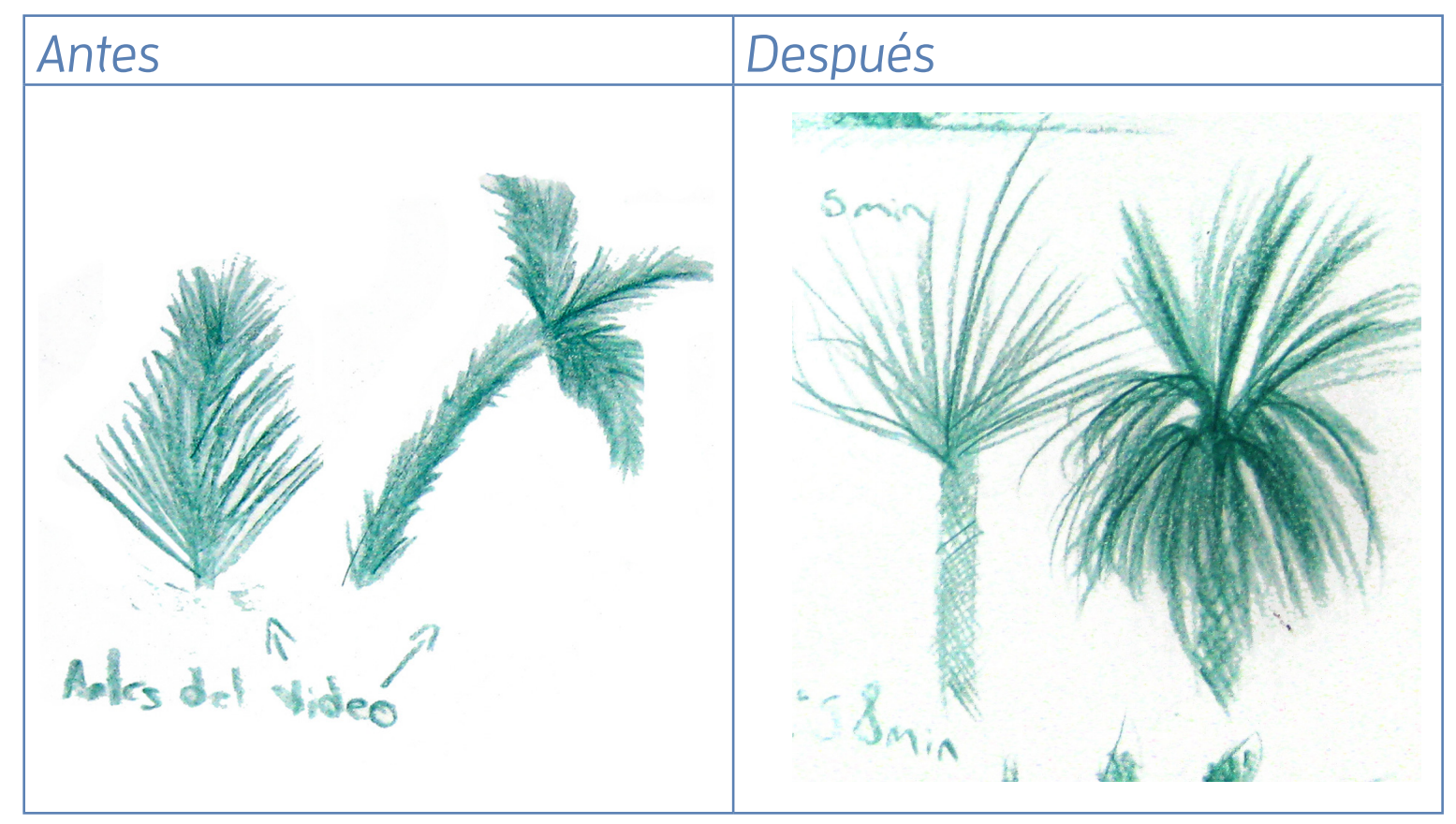

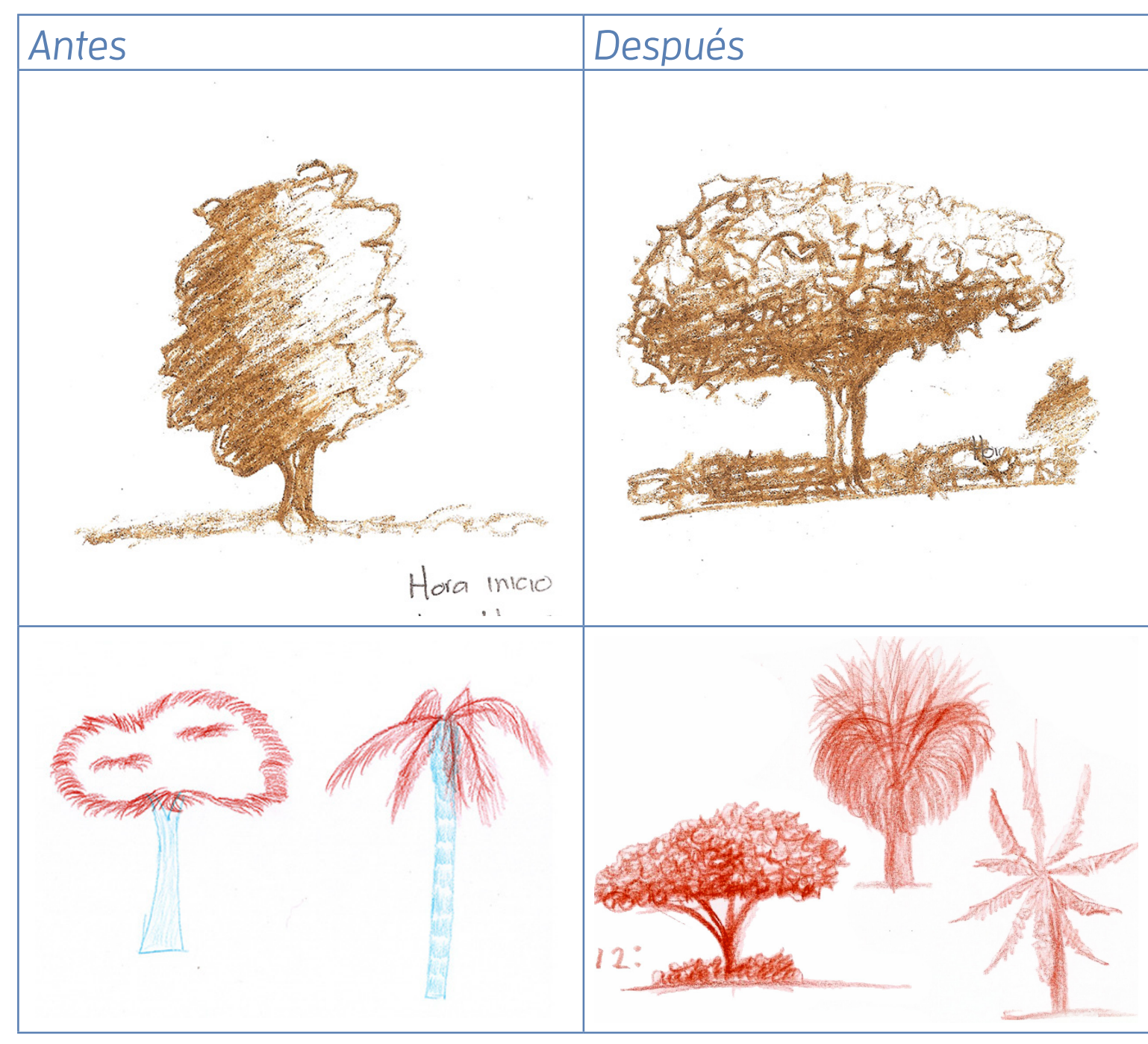

resultados gráficamente mejor logrados, resultados que habían sido atribuidos a su nivel académico, se autoevaluaron en general con conocimientos previos de nivel medio y un $75 \%$ de este grupo opinó haber mejorado mucho su habilidad de dibujo de árboles con lápiz de color, como se puede constatar en los resultados presentados en las Gráfica I a la Gráfica 4. 
Sobre el tutorial que practicó, ¿qué tanto conocimiento previo tenía del tema?

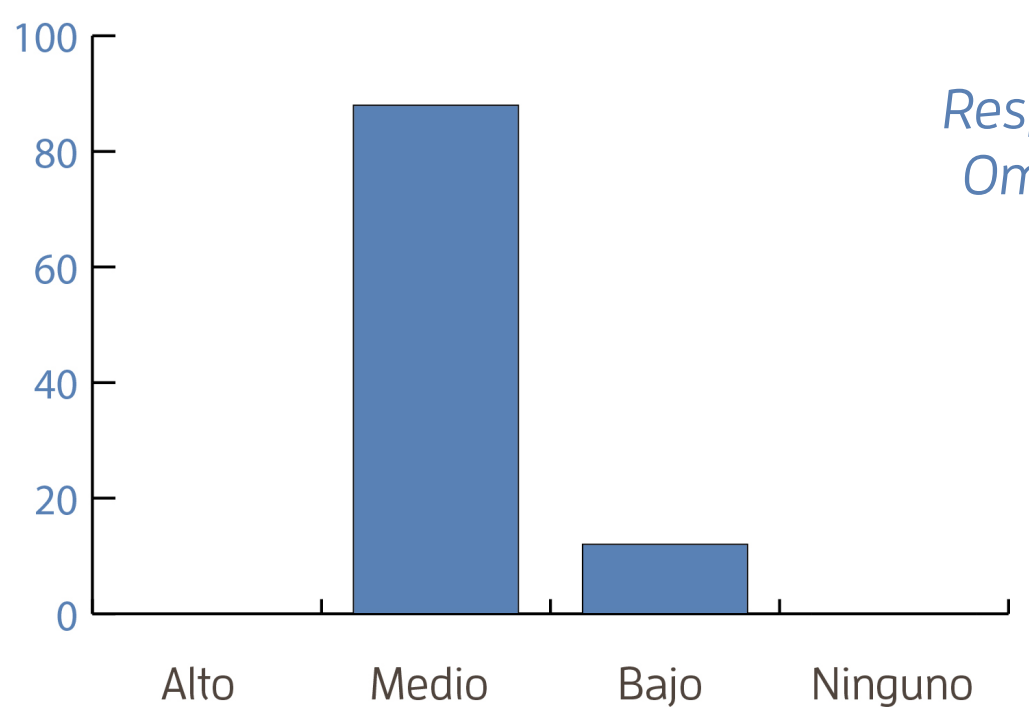

Figura 7. Grupo Focal A (semestres avanzados)

Conocimiento previo

En su opinión, ¿considera que la habilidad que buscaba reforzar con este videotutotual mejoró después de verlo?

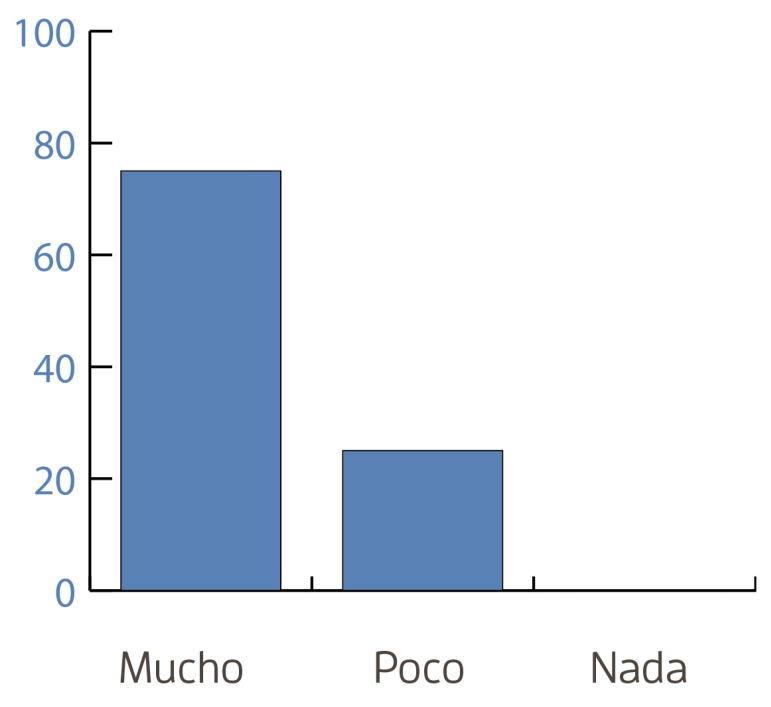

Figura 8. Grupo Focal A (semestres avanzados)

Grado de mejora
Sobre el tutorial que practicó, ¿qué tanto conocimiento previo tenía del tema?

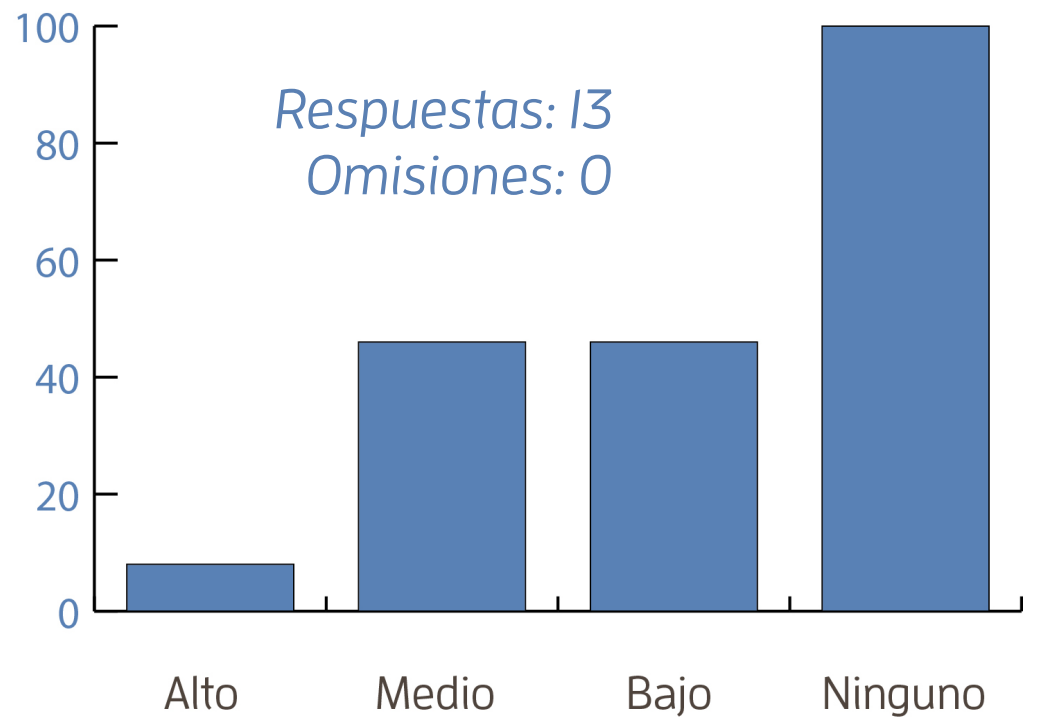

Figura 9. Grupo Focal B (semestres básicos) Conocimiento previo

En su opinión, ¿considera que la habilidad que buscaba reforzar con este videotutorial mejoró después de verlo?

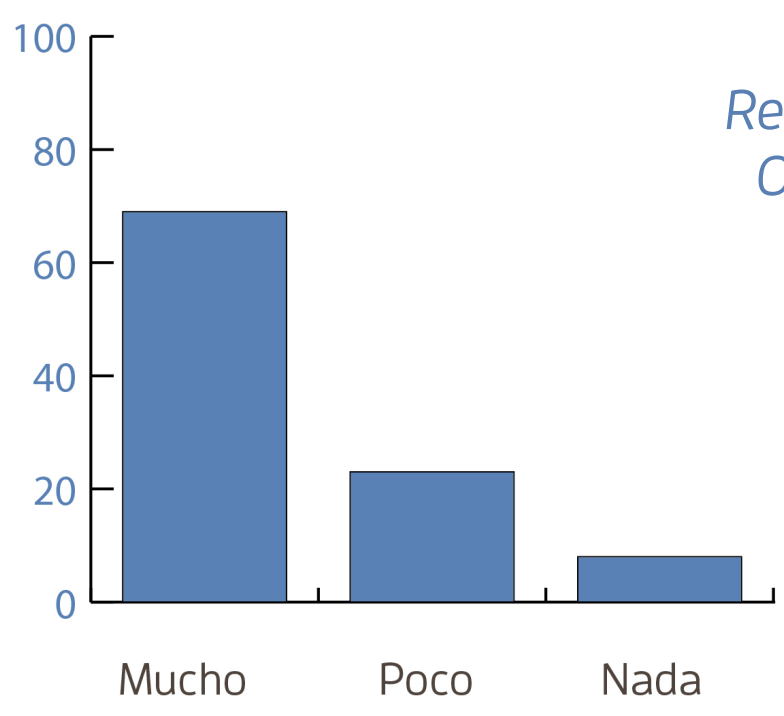

Figura 10. Grupo Focal B (semestres básicos) Grado de mejora 
Asimismo, se incluyeron preguntas generales sobre la calidad de los tutoriales presentados. El nivel de detalle de los tutoriales fue considerado de "muy" a "extremadamente" detallado por un $61.9 \%$ de los encuestados. A esta pregunta se le puso una contraparte respecto a la duración donde el $85.7 \%$ de los encuestados opinó que la duración de los videos era aceptable, solo el 14.3\% consideró que dicha duración fue corta.

Respecto a la claridad del instructor, los encuestados en su gran mayoría (81\%) opinaron que éste era claro a extremadamente claro. En cuestión de la calidad de imágenes y video, también la mayoría de los encuestados (76.2\%) opinaron que el video era suficientemente claro.

Once de trece encuestados regresaron el video para volverlo a ver de I a 3 veces para verificar detalles que consideraban se les habían pasado, o para observar de nuevo la técnica del instructor. Solo un encuestado no regresó nunca el video y solo uno lo regresó más de 4 veces o más.

También se incluyó una pregunta de carácter didáctico sobre los conceptos que se realzaban con texto sobre el video cuando los mencionaba el instructor. Únicamente 3 de 21 encuestados identificaron dichos letreros. Sin embargo, esto no se considera un problema, ya que la finalidad de los tutoriales es de refuerzo, para práctica, desarrollo y refuerzo de técnicas, y aunque adquirir la terminología correcta es importante y da espacio para estudio posterior, el objetivo final del video se sigue cumpliendo, a pesar de esa falla.

\section{Conclusiones}

Con los resultados de estas evaluaciones, se pretende medir la eficacia de estos medios en el desarrollo de las habilidades propuestas por los tutoriales y hacer en consecuencia los cambios pertinentes en las próximas sesiones de grabación. También hemos iniciado el desarrollo de un sitio web (www.dad.uson.mx/ tutoriales) que permitirá hospedar el banco de video-tutoriales a través de YouTube y un servidor de la Universidad de Sonora, para que puedan tener acceso al mismo los estudiantes y docentes del Departamento de Arquitectura y Diseño.

Como se comentó al inicio, aunque los video-tutoriales tienen como fin apoyar las materias de los programas presenciales de la Universidad de Sonora, también podrían apoyar la impartición de materias en línea como subproducto. Asimismo, luego de producir el primer grupo de videos y publicarlos, se espera seguir incrementando el acervo, y paralelamente conseguir financiamiento para convertir esto en una publicación académica - libro y DVD- donde se expliquen con más detalle los contenidos a través de texto, imágenes de alta resolución e hipervínculos al sitio web.

Aún hay mucho trabajo por delante, pero después de las pruebas iniciales somos optimistas en que el producto final tendrá buena aceptación entre los estudiantes; basta recordar el comentario insistente de varios de ellos el día que participaron en las pruebas: "¿Puedo llevarme copia de los archivos?", refiriéndose a los video-tutoriales que les fueron presentados, lo cual nos deja con la certidumbre que no solo les gustaron, sino que visualizaron una aplicación práctica inmediata de nuestros video-tutoriales en su beneficio. 


\section{Referencias bibliográficas}

Borges, F. (2005). La frustración del estudiante en línea. Causas y acciones preventivas. Digithum. UOC. No 7. Recuperado de http:// www.uoc.edu/digithum/7/dt/esp/borges.pdf

Burbules, N.C. (1999). El diálogo en la enseñanza: Teoría y práctica. Buenos Aires: Amorrortu.

Kaufman, P.B., \& Mohan, J. (2009). Video Use and Higher Education: Options for the Future. Nueva York: Intelligent Television, Copyright Clearance Center, New York University. Recuperado de https:// library.nyu.edu/about/Video_Use_in_Higher_Education.pdf
Kirkwood, A., \& Price, L. (2014). Technology-enhanced learning and teaching in higher education: what is 'enhanced' and how do we know? A critical literature review. Learning, Media and Technology, 39(I) pp. 6-36. Recuperado de http://oro.open. ac.uk/36675/I/TEL\%20in\%2OHigher\%20Education-What\%20 is \%20enhanced\%20and\%20how\%20do\%20we\%20know. pdf

Noë, A. (2004). Action in Perception. Cambridge: MIT Press.

Price, L., \& Kirkwood, A. (20II). Enhancing professional learning and teaching through technology: a synthesis of evidence-based practice among teachers in higher education. York, Reino Unido: Higher Education Academy. Recuperado de http://core.ac.uk/ download/pdf/285II4.pdf

Woolgar, S. (2002). Virtual Society? Technology, Cyberbole, Reality. Oxford: Oxford University Press. 


\section{Segunda parte}

Aplicación

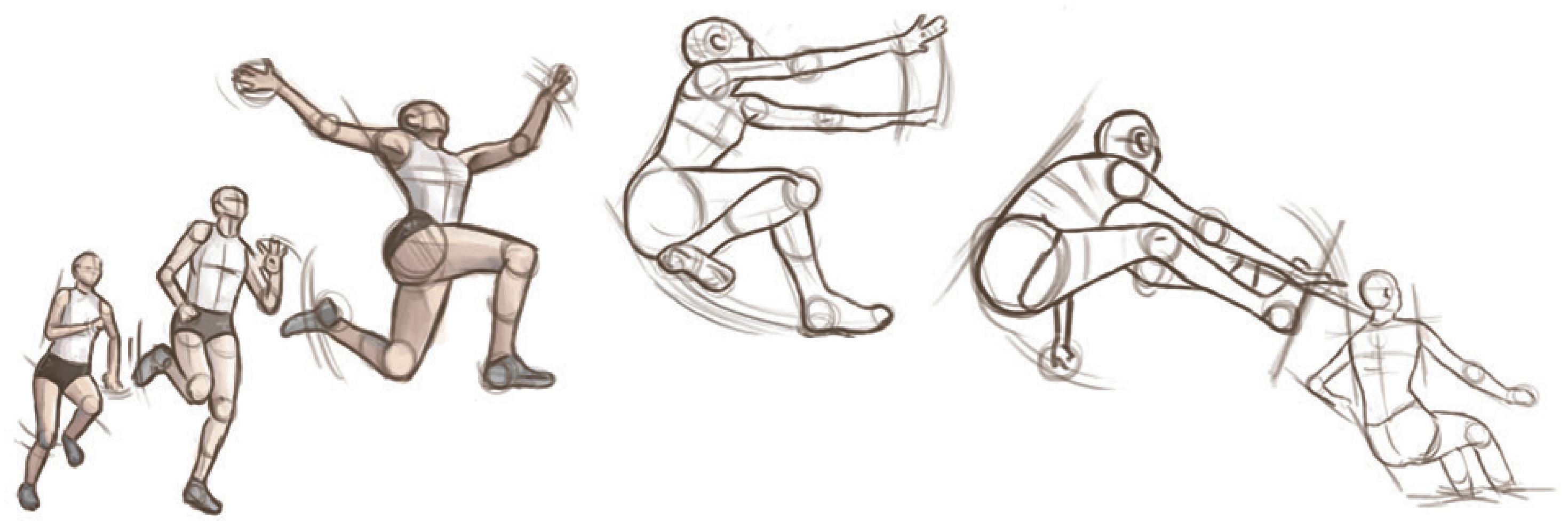




\section{Diseño de personajes}

para videojuegos

\author{
Iván Omar González Dávalos
}

\section{Introducción}

Este estudio surgió a partir de una serie de conversaciones con diferentes alumnos que gustan de los videojuegos y de cómo se ha querido abordar esta temática en nuestro centro universitario con resultados nada favorables.

Actualmente hay varios trabajos de diseño de videojuegos que se han trabajado en la escuela. Sin embargo, ninguno de estos trabajos sería admitido como un estándar aceptable dentro de la industria del juego. Les falta más análisis y más investigación desde la academia.

Hay dos razones para esto. Uno: que requiere una inversión considerable para realizarlo, y no sólo en equipo de cómputo, sino también en software especializado para diseño, modelado, maquetación y desarrollo del videojuego, si es que se quiere hacer algo atractivo. $Y$ dos: Los diseñadores del CUAAD no son programadores. No están capacitados en el área de la Ingeniería en Sistemas para que pudieran crear un videojuego desde esta etapa. Pero entonces, ¿en dónde entra un diseñador?

Conestas inquietudes en mente, en esta ponencia se hace una propuesta de cómo los diseñadores pueden entrar al mundo de los videojuegos, si no en la programación, sí en el arte conceptual, algo más afín a su preparación. Los diseñadores pueden abarcar desde el Diseño de Arte de objetos y escenarios hasta los personajes de videojuegos. Y es aquí donde está la parte esencial.

Se comienza por explicar los diferentes tipos de videojuegos, para conocer los diferentes tipos de temáticas que existen en el producto. Después con los diferentes especialistas involucrados en 
la producción de un videojuego; haciendo una pausa en el Diseño de Arte, lo que se debe considerar para la creación de personajes, iniciando por una historia atractiva e interesante, tomando en cuenta el tipo de videojuego a diseñar, así como también el sector de mercado al cual se dirige.

En la etapa de Arte se describe al personaje, basado en teorías de cine; se abordan primero las dimensiones físicas, psicológicas y socioculturales de los futuros personajes, para poder diseñar su aspecto. Y finalmente, poder crear un Art Book que servirá para el modelado digital y su posterior programación.

El diseño de videojuegos sigue siendo un reto difícil. Las herramientas y las teorías presentadas en este trabajo no pretenden eliminar este objeto de estudio en la escuela, sino desarrollar la creatividad y el ingenio humano que puede tener el diseño en nuestros alumnos. Lo que ayudará a ampliar más su preparación y conocimiento en su futura etapa laboral.

Hoy en día, en la industria de los videojuegos hay una gran variedad de compañías, dedicadas a la creación, diseño, edición y distribución. Todos estos desarrolladores se juntan de manera organizada para el desarrollo de títulos en las diferentes plataformas electrónicas. Si bien cada una de las empresas tiene un lugar muy específico, uno de los puntos fuertes es la creatividad, que en el diseño es parte medular. En la industria del juego, muchas personas no consideran realmente los pasos para la creación de videojuegos, menos en el arte conceptual. De hecho, pensar un videojuego sin la creación gráfica de estos, es viajar a ciegas.

En primer lugar, hay que distinguir varias ramas en el diseño de juegos de video y que se decidió ordenar de la siguiente manera:

- Creación

- Gestión de Negocios

- Publicación y distribución

- Prensa especializada

\section{METODOLOGÍA}

Partiendo de bibliografía e información referente a los videojuegos y a la creación de personajes, el presente trabajo pretende identificar y describir las diferentes etapas que implica su creación, haciendo más pautas en los aspectos significativos de los personajes. Un estudio en el cual se tiene como eje la ilustración gráfica de 2D y su exportación al 3D, lo cual se constituye por un proceso metodológico cualitativo, basada en una estrategia de estudio inductiva, utilizando descripciones de cada etapa, con el objetivo de mostrar los datos y etapas de forma más clara y cierta.

Se han determinado 3 etapas generales para el desarrollo del presente estudio:

I. Análisis descriptivo de las etapas en la creación de los videojuegos.

2. Definición de laspautas en el Diseño de Arte de los personajes.

3. Conclusiones.

\section{CREACIÓN}

Antes de seguir adelante con el tema, es importnte decir que existen muchos tipos de mini empresas que participan en la creación de un videojuego. Sin los desarrolladores - las compañías que los hacen- o proveedores - las empresas que llevan el producto a sus clientes - los videojuegos no podrían salir a la luz.

\section{Diseño de juegos}

El diseñador de videojuegos debe, sobre todo, conocer todos los aspectos del diseño; es quien tiene una idea general del proyecto. Estas personas tienen experiencia en los negocios (por ejemplo, Michel Ancel oShigeru Miyamoto que empezó como programador).

Hay dos rutas disponibles para llegar a ser diseñador de juegos, a través de las escuelas grandes o aumentar la experiencia a través de otras posiciones dentro de empresas de videojuegos, tales como jugador probador o diseñador de niveles. 
El trabajo de un diseñador de juegos es definirlos en su conjunto y garantizar la coherencia del producto. Se debe comenzar el proyecto mediante el establecimiento de unas "especificaciones" para determinar el tipo de juego (disparos, acción, entre otros), el objetivo (qué se hará en el juego), la plataforma que será utilizada y los objetivos de ventas. Es entonces cuando se diseñará el mundo del juego y sus mecanismos. Cuando se pone en marcha oficialmente la producción, el diseñador de juegos debe coordinar a su equipo y siempre garantizar la coherencia del proyecto.

\section{Definición del género del videojuego}

Para este paso, el diseñador de juego debe decidir qué género es el que escogerá para realizar su producto, debe definir con base en la demanda, pero sobretodo tomar en cuenta el contexto social y cultural al cual irá dirigido su trabajo. Existen diferentes géneros que a continuación se describen:

- Lucha. Estos juegos incluyen todos aquellos en los que el jugador es un luchador que debe tomar múltiples acciones físicas. Debe dominar el juego, aprender y ser capaz de producir buena secuencias de golpes y desarrollar las técnicas adecuadas para combatir a los enemigos y superarlos. Ejemplos de juegos: Street Fighter II, Fatal Fury, The King of Fighters, Samurai Shodown, Tekken o Mortal Kombat.

- Aventura. Son similares a los juegos de lucha, a diferencia que el jugador debe luchar contra muchos enemigos, progresando dentro de los niveles de dificultad creciente. La cooperación es común en este tipo de juegos, y por lo general juegan dos o más personajes. En la mayoría de estos juegos la acción se desarrolla en un entorno urbano. Los protagonistas son por lo general vigilantes que se enfrentan contra pandillas, punks, matones, prostitutas y traficantes infestando los niveles del juego. Ejemplos de juegos: Double Dragon, Golden Axe, Batman Arkham city, etc.
- Plataformas. Estos juegos se caracterizan por ser bases suspendidas para dar saltos o también saltar por encima de obstáculos, así como el librar diversas trampas, controlando un personaje. De vez en cuando, no solo se salta, también se puede nadar o volar. Otros elementos adicionales pueden ser de géneros como la lucha y el tiroteo. Mario Bros, Sonic y Rayman son figuras emblemáticas de este tipo de videojuego.

- Disparos. En este tipo de juego a partir de un personaje o vehículo, se dispara a los enemigos con armas, poderes y proyectiles para neutralizar a los enemigos. También el jugador debe asegurarse de moverse lo suficientemente rápido para cubrirse o evitar los ataques de fuego o cuerpo a cuerpo. Los juegos de disparos(FPS o Shooter) se basan en un objetivo y en perspectiva en primera o tercera persona. Esta perspectiva tiene como objetivo dar al jugador la sensación de estar en el lugar de la acción. Ejemplos de juegos: Doom, Halo, Half-Life, Counter Strike, Battlefield 3, Call of Duty, Gears of Wars.

- Sobreviviente. El estilo sobreviviente o de horror pone al jugador en un mundo amenazado en el que debe sobrevivir. Estos juegos utilizan elementos temáticos tradicionales de las películas de horror para crear un clima de peligro permanente, tales como monstruos (vampiros, zombis, dinosaurios), perturbaciones atmosféricas y otros temas. Un elemento clave del juego es la cantidad limitada de municiones y armas. Ejemplos de juegos: Silent Hill, Dead Rissing, Resident Evil.

- Juegos de rol. También conocidos como RPG, se basan en los clásicos juegos de mesa, tales como Mesa Magic o Calabozos y Dragones. La mayoría de ellos invitan al jugador a encarnar uno o más aventureros para especializarse en un campo específico (combate, magia, etc.) y así avanzar 
en la historia con una trama lineal. Sin embargo, estos juegos también ofrecen libertad de decisiones. Los temas más comunes son la fantasía. Ejemplos de juegos: World of Warcraft, EverQuest, Final Fantasy, etc.

- Laberinto. En este tipo de juegos el jugador es prisionero en un galimatías. Dentro del juego la meta del jugador es escapar de sus enemigos, además, recoge objetos dispersos por todo el camino. Ejemplos de juegos: Pac-Man, Bomberman, Dig Dug, etc.

- Rompecabezas. El videojuego del rompecabezas es un juego de puzzle en el que el jugador debe montar piezas. Este tipo de juegos coquetea con frecuencia con juegos de aventuras, juegos educativos, algunos juegos de Arcade, especialmente Tetris y similares. Ejemplos de juegos: Diamond Jewelry , Candy Crush, Tetris, o el Dr. Mario.

- Simulador. En estos juegos el jugador toma el papel de un planificador o un jefe para construir y gestionar un lugar, puede ser una ciudad, hogar, edificio o incluso a todo un pueblo; por ejemplo, el jugador puede proporcionar alimentos, vivienda, atención médica, renovación espiritual, recreación, crecimiento económico, etc. El éxito de estas tareas está estrechamente ligada al talento del jugador para dar beneficios y grado de satisfacción de los individuos digitales. Ejemplos: Springfield EI Videojuego, Sims, etc.

- Deporte. Los videojuegos de deportes incluyen muchas disciplinas, tales como béisbol, golf, tenis, fútbol, hockey sobre hielo, equitación, entre otras. La gran mayoría de ellos permite al jugador controlar no un personaje de ficción, pero sí un atleta real. Otros juegos de este tema ofrecen al jugador dirigir como entrenador cuya evidente finalidad es llevar a su equipo a la victoria. El objetivo no es establecer metas o puntos, pero sí gestionar el entrenamiento físico de los jugadores y el desarrollo de tácticas. Este tipo de juegos son unos de los más antiguos de la historia de los videojuegos y sigue siendo de los más populares hoy en día. Ejemplos de juegos: Ias series de FIFA, Tony Hawk Pro Skater, Madden, etc.

- Juegos de carreras. Ponen al jugador en control de un vehículo y se debe realizar una serie de vueltas sobre una pista de carreras, puede también luchar contra otros conductores con el fin de obtener un lugar en el podio. Otras veces, es simplemente llegar a la meta u obtener el mejor tiempo en pista. Este tipo de juegos se inspira directamente en el deporte motor que simula; realidad o no, hay dos subtipos: las carreras Arcade y la simulación de juego de carreras. Ejemplos: Fl, Mario Kart, Gran Turismo, etc.

- Movimientos y ritmos. Juegos electrónicos cuyo objetivo es seguir una secuencia de movimientos o mantener un ritmo particular con el cuerpo. Las partidas se juegan con un teclado, joystick, lector de movimientos corporales o réplicas de instrumento musical. Ejemplos de juegos: Dance Central, Guitar Hero, Dance Dance Revolution, etc.

\section{Personajes}

Referente al diseño de personajes, Seger (2000) utiliza términos teóricos interesantes que aunque son para el cine, también se puede aplicar a los videojuegos. En estos están las características particulares que delinean a un personaje.

Cada característica define la personalidad del personaje, y a su vez, cada personaje es parte de la historia que se muestra en el videojuego a diseñar. Las películas están narradas por lo general desde el punto de vista del protagonista (el principal personaje en una historia) como lo comenta Vidrio (2003).

Entre las características que debe tener un personaje, Seger (2000) menciona lo siguiente:

- El contexto: en el cual al personaje se le da características de su entorno cultural, político y lugar histórico. 
- Influencias culturales: en el cual se define al personaje su origen étnico, social, educativo, filosófico y sus aspectos de actitud y expresividad.

- Elperiodohistórico: es el tiempo donde se ubica al personaje en un lugar determinado.

- Los lugares: son los sitios donde va transitando el personaje para contar una historia.

- El impacto de la profesión: se define a qué profesión se dedica el personaje y por lo general el contexto es la profesión del personaje.

Estas particularidades que menciona Seger sirven para definir cada una de las características que debe tener un personaje para videojuegos; desde el enfoque del protagonista en la mayoría de las veces, estas características ayudan a analizar el contexto que rodea los personajes virtuales.

El jugador ve en el videojuego, desde el punto de vista del protagonista, que durante el juego asume diferentes papeles dentro del film game. De acuerdo a Aumort y Marie (I999):

Por definición, el punto de vista es el lugar desde el cual se mira. De manera más general, es también el modo en que se mira. En el film narrativo, este punto de vista, durante la mayor parte del tiempo, se asigna a alguien, ya sea uno de los personajes del relato, o bien, expresamente, el responsable de la instancia narrativa (pp. 154).

La visión exterior es la más utilizada en el guión. Se narra entonces desde el punto de vista de un personaje determinado, presente como partícipe o testigo de la mayor parte de las escenas que componen el filme, y el espectador sabe solamente lo que se nos deja ver o saber. El guionista decide desde qué punto de vista contará su historia; es decir, con qué modo de narración va a funcionar (pp.40).
Aumort y Marie (1999) y Vidrio (2003) dicen que tanto en el cine como en el guión, en este caso en los juegos, hay un personaje a seguir como partícipe del mayor número de escenas en una película. En el caso de los videojuegos siempre se juega con uno o con varios personajes, y más aún, se toman decisiones por ellos. En la Tabla I se muestra una serie descripciones que se deben tomar como propuesta para el diseño de personajes para videojuegos.

Tabla I. Dimensiones a considerar para el diseño de personajes.

\begin{tabular}{|c|c|}
\hline \multicolumn{2}{|c|}{ Dimensión Física-Fisiológica } \\
\hline Sexo: Masculino o femenino. & Edad: qué tan joven o viejo es. \\
\hline $\begin{array}{l}\text { Descripción física: Complexión for- } \\
\text { nida, delgada, mediana. }\end{array}$ & $\begin{array}{l}\text { Apariencia: color de cabello, ojos, } \\
\text { boca, piel. }\end{array}$ \\
\hline \multicolumn{2}{|c|}{$\begin{array}{l}\text { Defectos (deformidades o enfermedades): señas particulares, lunares, } \\
\text { cicatrices, etc. }\end{array}$} \\
\hline \multicolumn{2}{|c|}{ Dimensión Social } \\
\hline Clase social: Baja, media, alta. & $\begin{array}{l}\text { Ocupación: a que se dedica el per- } \\
\text { sonaje. }\end{array}$ \\
\hline Educación: nivel de estudios. & Religión: cuál es su fe. \\
\hline $\begin{array}{l}\text { Nacionalidad: en dónde vive, país, } \\
\text { planeta, ciudad. }\end{array}$ & $\begin{array}{l}\text { Filiación política: cuáles son sus } \\
\text { ideales. }\end{array}$ \\
\hline \multicolumn{2}{|c|}{ Hobbies: que es lo que hace en su tiempo libre. } \\
\hline \multicolumn{2}{|c|}{ Dimensión Psicológica } \\
\hline \multicolumn{2}{|c|}{ Historia familiar: cuál es su origen, de dónde viene, sus padres, pareja, etc. } \\
\hline \multicolumn{2}{|c|}{ Vida Sexual: su actividad física con parejas del mismo u otro sexo. } \\
\hline $\begin{array}{l}\text { Autoestima: qué tanta confianza } \\
\text { tiene en sí mismo. }\end{array}$ & $\begin{array}{l}\text { Actitud frente a la vida: cómo toma } \\
\text { los retos. }\end{array}$ \\
\hline Habilidades: qué sabe hacer. & Cualidades: para qué es apto. \\
\hline I.Q.: qué tan inteligente es. & \\
\hline
\end{tabular}




\section{Diseño de Arte}

En esta etapa entran los diseñadores de carrera, en su gran mayoría son diseñadores gráficos, industriales o artistas plásticos que se dedican a la identidad visual del videojuego, a continuación se explica esta etapa.

- Gráficos 2D. El diseñador, bajo la dirección del director artístico, participa en el desarrollo y diseño de los decorados y personajes de acuerdo con las ideas del guionista o diseñador del juego. Su función se puede comparar a la de un ilustrador. De hecho, el diseñador en esta etapa crea personajes en diferentes expresiones y establece ángulos específicos de cuerpo y rostro. Por supuesto, el talento del dibujante es de los más importante para este tipo de características del trabajo.

- Modelador 3D. El trabajo de un modelador es transformar los ambientes y los personajes de la ilustración del juego en objetos 3D integrados en el motor gráfico desarrollado por el programador, debe de llevar los dibujos a personajes y escenarios virtuales. También debe optimizar el diseño de los objetos en el juego por las limitaciones del renderizado en tiempo real.

- Stopmotion. La tarea es poner los objetos y a los protagonistas del videojuego creados por el modelador en personajes con movimientos reales. Teniendo en cuenta el modo y la historia del juego, es el director de esta etapa quien determina los movimientos de los personajes y objetos, adaptados a través de diferentes técnicas. Un director en Stopmotion es ante todo una persona con un buen sentido del teatro, de la puesta en escena.

- Diseñador de sonido y música. En esta etapa trabaja en estrecha colaboración el diseñador del juego y el director de arte, se establece la atmósfera general del juego, como la música, los efectos sonoros y los diálogos de los personajes.
En la fase de producción, se registran en un estudio de grabación los diálogos, la música - compuesta por músicos o no - y los sonidos ambientales implícitos en el videojuego.

\section{PERSONAL INVOLUCRADO}

\section{Diseñador de Niveles}

El diseñador de nivel es aquel que permanece en contacto constante con el equipo de Diseño de Arte. De hecho, son los productos visuales gráficos los que llevan al diseñador de niveles a implementar los grados de jugabilidad en el videojuego, así como la historia. Por ejemplo, se ponen objetos en el entorno con el fin de tener un modo de juego satisfactorio. Además, da los caminos a seguir para el jugador y establece la dificultad general del juego. Por último, debe tener conocimiento de conceptos básicos de programación que a veces son necesarios para escribir los escenarios del juego.

Si se hablara con un lenguaje cinematográfico, el diseñador de niveles debe trabajar con el guionista, para idear una historia y personajes atractivos.

\section{Experimentador}

Pone atención a los errores de jugabilidad. El Experimentador o probador debe ser absolutamente un gamer con experiencia. Este especialista tiene un trabajo de tiempo completo en el diseño de un juego. De hecho, su misión es encontrar todos los errores y defectos del juego, además de evaluar el problema y garantizar el funcionamiento completo del proyecto, tomando nota de todas las observaciones que encuentre. Debe entonces, presentar informes precisos sobre esas inconsistencias para su corrección.

A pesar de su trabajo repetitivo y un salario no tan motivador, ser jugador analista es a menudo una puerta real en la industria. 


\section{Programador}

Es la persona que escribe en un lenguaje de códigos informáticos, que se utilizan para controlar la imagen y el sonido en función de las acciones del jugador. Hay varios tipos de programadores que están especializados en motores virtuales, ya sean gráficos o de jugabilidad. La mayoría se centra más en el juego en sí, como trayectorias programadas tomadas por un héroe o acciones de los personajes.

En todos los casos, el programador o los programadores deben escribir varias líneas con códigos respecto a los personajes, los sonidos y el escenario definidos en etapas anteriores. Una programación del juego puede incluir decenas de miles de línea de código, por lo que la disciplina y la organización son claves para este negocio. Por lo tanto, es casi imposible imaginar hacer esto sin haber estudiado ingeniería informática.

\section{Director de proyectos}

Es aquel que asegura la buena marcha del videojuego, tanto en tiempo como en términos del presupuesto. Aseguraque losequipos de trabajo cuenten con los medios necesarios para alcanzar sus objetivos. También es un gerente porque debe cumplir horarios, comunicarse con sus equipos y resolver los problemas humanos. Además, él es el primero en la línea para comunicarse con los editores o fabricantes. El director del proyecto debe organizarse y saber todo el proceso de creación de un videojuego.

Esta persona, por lo general, viene de la carrera de administración, de gestión o incluso de negocios y cuenta con una amplia experiencia en gestión de proyectos.

\section{GESTIÓN DE NEGOCIO}

\section{Publicidad y distribución}

Después de haber tratado con la creación del videojuego en sí y su administración logística, no olvidemos incluir la etapa de publicidad y distribución. Después de todo el proceso creativo de los videojuegos, comienza la etapa de publicidad, distribución y comercialización de los juegos de video; los responsables de esta etapa son los siguientes:

- Responsable del área de comunicación

- Jefe de finanzas

- Asistente de dirección y comercialización

- Responsable de distribución

- Jefe de prensa (general o especializada)

- Productor del videojuego

- Webmaster (sitio web y redes sociales)

Estas operaciones se pueden agrupar en cuatro áreas principales, cada uno con diferentes funciones y puestos de trabajo. En la división de marketing, por ejemplo, los gerentes del producto se hacen cargo de los compradores, mientras que el administrativo y financiero es responsable de toda la contabilidad y los aspectos legales. Otra división importante es la producción del videojuego, los productores dan seguimiento al proyecto de principio a fin, gestionan con los probadores del juego, así como también tienen relación con los webmaster que los mantienen al tanto de la web y las redes sociales.

Respecto a lo comercial, entran las tiendas especializadas, la distribución de los juegos necesita lugares para vender o el desarrollo de negocios que permita encontrar nuevas vías de distribución y venta del producto.

Estos oficios en realidad no han cambiado en los últimos diez años, pero ahora están evolucionando drásticamente debido a los 
cambios del mercado relacionados con la desmaterialización, es decir, los videojuegos ya se pueden vender y descargar en línea, ya no se necesita tener un disco.

\section{Prensa especializada}

Otra posibilidad en el universo del diseño de videojuego, a veces sin goce de sueldo, es la prensa especializada, la que informa a los jugadores de las novedades y análisis de los videojuegos. Se especializa no solo en la publicación escrita en prensa sino también en formato digital gracias a internet. En la actualidad, destacan los editores y trabajadores independientes; los primeros se asocian a menudo con una editorial y reciben un sueldo fijo, mientras que a los trabajadores independientes se les paga por el número de artículos producidos.

Además, en una publicación existen varias funciones que se pueden describir:

- Un editor que coordina la redacción

- Jefes de secciones

- Editores

- Correctores

No se requiere un tipo de formación académica para convertirse en un periodista en videojuegos, pero se requiere pasión y grandes habilidades en la escritura. Por supuesto, ir a una escuela de periodismo no va a aumentar las posibilidades de entrar a una revista especializada. Por ejemplo, una gran mayoría (90\%) de los periodistas en los medios de comunicación amarilla no vienen de escuelas de periodismo.

\section{CONCLUSIONES}

En relación con el estudio que se planteó para realizar la presente investigación que fue describir la creación de personajes para videojuegos, se pudo detallar los diferentes componentes técnicos, visuales y artísticos para la creación de videojuegos. Se puede concluir que:

- En todos los videojuegos va implícita la creación de una buena historia tomando en cuenta el mercado meta que se quiera abarcar.

- En el caso de la parte del diseño de personajes se debe tomar en cuenta la historia base del videojuego para poder hacer un óptimo diseño visual de los personajes.

- En la parte de la creación de personajes, se debe pensar en la etapa posterior de la ilustración y dibujo. Debe pensarse que los personajes van para medios digitales de modelado y animación.

Se puede pensar que trabajar los personajes y por consiguiente un videojuego, es muy fácil, pero no lo es del todo; como dice Rivera (20I0), "El concepto identidad es un componente básico de la cultura, es la autopercepción frente a la diferencia y esta se modifica respecto al referente. Es un sentimiento de solidaridad con una colectividad imaginaria". El diseñador debe considerar qué videojuego esta trabajando, a qué mercado quiere llegar y ver qué lo hace diferente a otros desarrolladores y demás juegos; si en un principio no lo visualizó, está en sus manos crear esa identidad. 


\section{Referencias bibliográficas}

Aumont, J., \& Marie, M. (1999). Análisis del film. Barcelona: Paidós.

Rivera, E. (20I0). Cancha Libre: Metodología para la investigación social del deporte y la comunicación. Hermosillo: Universidad de Sonora.
Seger, L. (2000). Cómo crear personajes inolvidables. Barcelona: Paidós.

Vidrio, M. (2003). Escribir para el cine. México: Universidad de Guadalajara. 


\section{Estrategias didácticas asociadas} al uso de programas

\section{computacionales para la composición en el diseño}

\section{Introducción}

En las últimas tres décadas la actividad del diseño gráfico ha evolucionado de manera constante y casi imperceptible, parece una actividad totalmente distinta a la que se realizaba en la década de 1980. Sin embargo, algunas de las estrategias de enseñanzaaprendizaje relacionadas con el diseño y composición no parecen seguir con esta evolución, pues aunque han ido cambiando, no van de la mano con las nuevas tecnologías.

Aquí se pretende brindar las bases para generar alternativas de estrategias en el proceso de enseñanza en la composición y estructura del diseño, acompañadas de herramientas tecnológicas presentes en la mayoría de los fabricantes de software y que pueden aprovecharse para generar imágenes casi instantáneas en conjunto con nuestras estructuras mentales al momento de su uso con estos programas.

Es importante señalar que la apertura de grupos de conocimiento sobre todo a nivel de enseñanza en programas de licenciatura donde se pretenda brindar bases de diseño estructural puede apalancar nuevas tendencias en el aprendizaje de esta actividad.

\section{Evolución del Diseño Gráfico}

El diseño gráfico ha evolucionado de manera sustancial. La forma de elaboración de originales mecánicos los cuales eran a base de estilógrafos, escuadras y papeles satinados, acompañados de una larga jornada y una taza de café, hacían que las horas pasaran lentas para llegar a unos cuantos trazos en el papel. En caso de 
ser necesario, se iba a "parar tipografía" al lugar de menor costo, indicando el tipo, tamaño, interlineado y ancho de columna para obtener galeras que pasarían a la hoja de trabajo previamente trazada con unas líneas azules indicando los márgenes, columnas y medianiles. Las cruces donde irían colocadas las fotografías o los cuadros de color negro se hacían presentes para ser sustituidos por las fotografías que de manera proporcionada, serían indicadas en las mismas imágenes. Si existía más de un logotipo, se podía ir a un taller de fotomecánica a copiar la cantidad de veces que fuera necesario para pegarlos en los recuadros señalados para ello. Si las líneas eran de diferente grosor, se tenía estilógrafos de $0.1,0.2,0.5$ y I pt o más según fuera necesario. El pegamento para las galeras podía encontrarse en líquido, el cual era aplicado con una brocha o en el mejor de los casos se encontraba por un precio no tan bajo en forma de aerosol. En caso de error, simplemente había que volver a empezar.

\section{La inteligencia visual del ser humano en el campo del diseño gráfico}

El diseño gráfico tiene sus principios en la comunicación visual. Desde esta premisa puede incluirse al diseño en todos aquellos medios que dirigen su impacto al sentido de la vista, aunque no pueden descartarse aquellos medios que aún sin la imagen, pueden estimular la imaginación, como por ejemplo, la radio. Mediante el sentido del oído se obtiene el material necesario para crear un mundo gráfico a partir de los propios pensamientos y experiencias, de este modo, aquello que se escucha puede ser trasladado a campo visual mediante la imaginación. Es así como se generan ideas y conceptos generales, además de vocabulario acorde a los elementos que se están creando. Es común que los libros de diseño comiencen por introducir aspectos de terminología basados en pensamientos filosóficos a términos como línea, punto, silueta, contorno, área, en el entendido de que como objetos no existen, pero se puede aceptar debido a que son utilizados como herramientas para crear formas, meramente subjetivas, pero que muy probablemente sean interpretadas por todas las personas 0 al menos por un buen porcentaje como válidas de acuerdo a lo que el diseñador desea comunicar.

Entonces, ¿cómo es posible que las personas puedan reconocer las figuras, imágenes y dibujos de igual forma como lo hacen otras ? Existen diversas teorías y estudios, como los señala-dos por Hoffman (2000, pp. II-39) en "Inteligencia Visual", que proporciona un panorama de esta inteligencia con respecto a otras especies del reino animal. Señala que la inteligencia visual tiene leyes que el mismo hombre ha creado a partir de su interpretación y que nadie le ha enseñado a interpretar eso que ve pero, sin duda, lo que la mayoría puede ver es prácticamente igual para todos aquellos que no tienen trastornos de la vista o dentro del cerebro, y que serían aquellos que sufren ciertos trastornos los que no pudieran interpretar lo que ven como lo hará el común de la gente.

A partir de estos principios, el ser humano va desarrollando campos de especialización dedicados a estimular las áreas del cerebro que se excitan por ciertas características de los objetos que se ven. De este modo, se genera dentro de ciertos rangos, limitaciones provocadas por cambios de luz y sombra, que se han conceptualizado como líneas, mismas que dan lugar a las formas. También aquí se encuentran los principios que originan la interpretación de la perspectiva y las imágenes estéreo que dan lugar a la tridimensionalidad.

Una vez que se puede señalar que se ve lo mismo, en función del ojo y del cerebro, también puede entenderse que no todos interpretan exactamente lo mismo. $Y$ es dentro de este contexto que se buscan formas creativas para tratar de comunicar mediante los elementos gráficos que se han desarrollado principalmente a través del arte. 


\section{Programas Computacionales}

Para principios de los 90 comenzó el cambio. Si bien ya era posible llevar un texto capturado en un disco de 5 1/4 y otro para correr el procesador de texto que pasaba un maestro o compañero que lo consiguió en el centro de cómputo que ya poseía procesadores AT, mismos que sustituirían a los XT para correr a una velocidad mayor, de modo que las tareas se volvían un poco menos tediosas, pero tediosas al fin. El software de diseño ya podía hacer un esquema en líneas del diseño y mediante un preview se veía un render que tardaba un minuto en el mejor de los casos. En el diseño editorial, la visualización de los textos simulaba el tamaño y el interlineado, pero no era hasta el momento de imprimir que podíamos ver las características totales de la letra, de acuerdo a un catálogo que se tenía a la mano para ello. Para realizar una textura, se podía copiar y pegar los objetos y desplazarlos a discreción, sacrificando un tanto más de tiempo de acuerdo a la velocidad de procesamiento. Los procesadores AT ya habían crecido de los 286 a los 486. Para los principios del año 2000 ya se presumían los procesadores Pentium y las computadoras Macintosh se conseguían del color que más era de agrado.

A finales del siglo $X X$ y en lo que va del siglo $X X I$ se ha utilizado paulatinamente y cada vez de mayor y mejor forma las computadoras. En el terreno del diseño gráfico han contribuido a la mejora de la presentación y mayormente se utiliza en la última etapa del proceso: la ejecución.

En apoyo a la ejecución, surgieron tres categorías de programas enfocados al diseño gráfico y sus medios de representación estáticos y dinámicos, como son periódicos, revistas, carteleras, y todos aquellos que eran reproducidos por cientos o miles en todas las ciudades. Estos programas prevalecen en la actualidad y se dividen en: vectoriales, mapa de bits, autoedición, animación y tridimensionales. Dentro de los vectoriales, los más comunes son el Macromedia Freehand, Adobe Illustrator y Corel Draw. Los dos primeros lanzados al mercado para la plataforma Macinstosh, creada principalmente para ambientes gráficos, y el último creado para la PC. Este primer grupo de programas ha contribuido al perfeccionamiento de trazos con ayuda de dispositivos de entrada como mouse y tabletas digitalizadoras, y dispositivos de salida como impresoras de inyección de tinta, láser y color.

Los programas vectoriales trabajan con base en trayectos, mismos que en principio, presentan el problema de asociación directa a los contornos y que se convierten en una tarea difícil de interpretar si no se tienen los elementos básicos del diseño transportados al uso de estos programas. Situaciones comunes son la de crear líneas que simulen objetos en lugar de buscar la forma global basada en figuras geométricas.

Dentro del segundo grupo de programas se encuentran algunos como el Paintbrush, Corel PhotoPaint y Adobe Photoshop, siendo éste último el que repuntó en el mercado $y$, actualmente, el más utilizado para escanear, recortar y editar fotografías, además de crear efectos especiales que difícilmente otros programas pueden lograr. Mucha de la aplicación de este software está basada en la simulación con medios artísticos para la representación y algunas de las características se asemejan a los trabajos con acuarelas, prismacolor, aerógrafo y carbones, en función con la emulación de diversos medios asemejan papeles, texturas y efectos especiales.

El tercer grupo lo conforman los programas dedicados a crear páginas múltiples para crear libros, revistas, folletos y en general al diseño editorial, destacando el QuarkXpress, Adobe Indesign, Adobe Pagemaker y otros creados para ediciones caseras. Todos ellos han revolucionado la forma de hacer diseño, pero han adaptado mucho de lo que anteriormente se utilizaba a los programas de cómputo. Así, términos como copiar y pegar, escritorio, mesa de trabajo y otros más, han sido recuperados de la forma ortodoxa de trabajar en las oficinas y centros de trabajo. 
El cuarto grupo está directamente relacionado con el diseño de páginas web, animación y diseño dinámico para diversas aplicaciones. Los programas de mayor auge son Adobe Flash, Adobe Dreamweaver, Adobe Director y algunos para soporte HTML.

El último grupo de programas son los que realizan modelado en 3D como Autodesk Autocad, Autodesk 3D Studio y algunos otros para diseño CAD y CAM.

Son muchos los aspectos que influyen en la actualidad para tomar una decisión adecuada al momento de elaborar un diseño en los programas que se han mencionado, se señalará un par que se ha vuelto de suma importancia en la elaboración del diseño. El primero de los aspectos tiene que ver con la elaboración de bocetos antes de la elaboración del diseño final. Es un tema de discusión que prevalece hasta la actualidad si el diseñador debe utilizar la computadora sólo para representar la idea final o puede también utilizarla para crear bocetos; el otro aspecto, es que todos poseen un esquema de color para su conversión entre los diversos modelos. Las pantallas se basan en el modelo RGB, mismo que se utiliza para diseño web, mientras que los diversos medios impresos pueden utilizar otras formas de color, como el caso de la impresión tradicional, que utilizan el modelo CMYK y los colores Pantone. De no tener un control adecuado puede variar de manera determinante el comportamiento del color, creando un impacto visual diferente al que se planteó inicialmente.

Las influencias en el uso de métodos tradicionales contra el uso de la computadora para procesos similares es también una situación polémica, pero para la didáctica queda mucho más claro que es necesario desarrollar primeramente la función de la mano con el cerebro, para posteriormente utilizar la computadora como una extensión del cerebro. Aunque el tema central es que son procesos complementarios, no se descarta que se trabaje a la postre en nuevos procesos que adapten las conexiones cerebro-mano con las cerebro-computadora. Para ello habrá que comprobar su funcionamiento con las metodologías necesarias.

Otro tema de debate, es tomar en cuenta las ventajas que cada método representa, siendo las más mencionadas dentro del dibujo a mano la conexión de la mano con el cerebro, la accesibilidad que representa el tener un lápiz y un papel para realizar los primeros esbozos, mientas que en la computadora se hace más difícil esa comunicación al ser necesario un dominio de la tecnología y las aplicaciones, así como los costos que representan al momento de la realización, inclusive la gran desventaja que puede representar el mostrar un diseño en pantalla, dentro de las que se encuentra la posibilidad de un cambio notable en el color, no visualizar correctamente el tamaño en comparación al producto final y que no sea tangible el material que se va a utilizar.

\section{Haciendo un poco de historia en el campo del diseño}

Desde que el ser humano se organizó en sociedades se ha visto cada vez más la necesidad de trascender, y muchos aspectos han sido plasmados mediante el uso de gráficos, así se encuentra una serie de elementosque han transformado la forma de comunicarse, desde las imágenes en cavernas hasta la escritura.

Con la llegada de la Revolución Industrial, se potencializó el trabajo en el diseño gráfico debido a que se podían reproducir más trabajos y con mayor semejanza al original. Surgieron la fotografía y la prensa como soporte a la actividad de información y comunicación. Estos medios junto con los habituales que ya eran utilizados para la representación han ido evolucionando, incluyendo materiales como papeles, pigmentos, tintas y desde luego, nuevos medios de comunicación.

Actualmente se está en una nueva era digital, la tecnología está prácticamente al alcance de cualquier persona, puede encontrarse impresión digital en sistemas que pertenecían al offset, 
al escaneo de imágenes realizadas en medios artísticos tradicionales para incluirlas posteriormente en el diseño y que ahora pueden ser realizadas desde la misma computadora. Ha desaparecido prácticamente la cámara fotomecánica manual para dar lugar a sistemas de salida a negativos, direct to plate (placas digitales) e impresión láser en diversos formatos, todos estos en empresas que lo hacen en el mismo día o inclusive al instante.

Meggs(2000) explica las diversas etapas y algunas corrientes que han dado lugar a los cambios a lo largo de la historia del hombre. El aspecto más importante a señalar es precisamente la formación académica con inclinación hacia la expresión gráfica que tenían aquellas personas que fueron parte importante dentro de la evolución y que fueron la pauta para el desarrollo innovador.

Tal es el caso de la identidad para los Juegos Olímpicos de México en 1968, elaborado por el arquitecto Pedro Ramírez Vázquez en colaboración con Lance Wyman; y el nacimiento del canal MTV, cuya imagen fue elaborada por los socios Pat Gorman, Frank Olinsky y Pat Rogoff, todos ellos con formación en bellas artes y con antecedentes familiares en ilustración y actuación.

\section{El diseño gráfico como actividad basada en los proceso y los procedimientos}

En el desarrollo del diseño se van presentando situaciones a resolver en dos sentidos: el primero está relacionado con los procesos mentales para generar ideas y el segundo está ligado a la tecnología para representarlo. Los procesos resolverán parcialmente la situación para satisfacer las necesidades de un cliente en función de lo que se pretende trasmitir en forma de mensaje. El segundo tiene que ver con las características del producto para que se conserve el mensaje; es aquí donde se vuelve importante el uso adecuado de la tecnología, incluyendo las que se relacionan con materiales, color y calidad de impresión.

\section{La didáctica del diseño}

Se asume que el uso de las tecnologías motiva a los usuarios para el soporte del aprendizaje, como lo menciona William (2000); el proyecto se desarrolla a partir de la necesidad de fomentar el aprendizaje centrado en el alumno y el conocimiento. Los alumnos pueden trabajar en equipos integrados para completar tareas productivas. La parte más importante de este proyecto equiparable a las necesidades actuales del diseño es la retroalimentación. Mientras que en proyectos de investigación es posible simular efectos provocados por alteración de diversas situaciones, dentro del diseño es posible que ellos mismos se den cuenta de alternativas que van encontrándose mientras más se desarrolla una idea.

Un aporte más de la tecnología a la educación es el aprendizaje mediante proyectos. Guzdial (2000) menciona que deben cubrirse tres requisitos para obtener buenos resultados: la oportunidad de reflexionar sobre su aprendizaje; objetivos basados en la construcción de conocimientos y brindar apoyo necesario para que logren sus objetivos.

Algunas teorías educativas como el conductismo, cognoscitivismo y construccionismo, son tomadas como modelos adecuados a las distintas áreas de aplicación. La expresión gráfica tiene un reto importante en las nuevas formas de aplicación del conocimiento, incorporando tanto aportes tecnologícos como teorías más adecuadas para el estímulo de la creatividad. La socialización es un factor determinante, ya que el alumno construye su propio aprendizaje e intercambia estructuras mediante la negociación social.

Dávalos, Maciel y Orozco (2009) mencionan al Blended Learning como una alternativa del constructivismo para fomentar el aprendizaje mediante el trabajo docente-alumno y alumnoalumno. Ya se ve aplicado el intercambio de estructuras que plantea el modelo constructivista para la socialización. 
En esta parte, se está trabajando actualmente para fortalecer el conocimiento cada vez más expansivo. Sólo con el apoyo adecuado de la tecnología se podrá apuntalar hacia un mayor y mejor uso de los recursos.

El aprendizaje de la actividad del diseño gráfico va cada vez más con una orientación de estímulo, creatividad, desarrollo del trabajo en equipo, métodos de evaluación grupal que están estimulando la parte sensible, humana, enfocados hacia un pensamiento divergente.

Estévez (2002) propone un modelo que resulta rescatable en varios sentidos para la realización de un diseño didáctico en cualquier nivel. La propuesta se genera a partir de cinco fases, comenzando por la elaboración de fundamentos y directrices curriculares, seguida por la formulación de objetivos y esbozo de los contenidos. De ahí continúa la organización y desglose de contenidos y formulación de objetivos curriculares; la cuarta fase es la selección y desarrollo de estrategias didácticas y finalmente, se formula el sistema de evaluación del aprendizaje.

\section{Nuevas estrategias de aprendizaje en el diseño y composición}

El uso de instrumentos en el ejercicio del diseño tiene que ver con aquellos que involucran a la mano, que es la que directamente realiza las funciones similares a una pluma. Dentro de los dispositivos de uso común se encuentran los ratones, tabletas graficadoras, pads y algunos otros que se quedaron en el camino. Cada uno de ellos tiene un potencial diferente. Los pads que incorporan las laptops son prácticos en el sentido de que no hay que hacer conexiones de ningún tipo debido a que vienen incorporadas en el equipo, sin embargo, su uso no es del todo práctico. Las tabletas graficadoras son más versátiles, pero requieren una conexión y traslado, motivo por el cual no se utilizan con frecuencia en el aula de clases. El ratón es un dispositivo que nació hace 30 años y no ha desaparecido. Se han agregado mayor número de botones y es muy popular para los aficionados a los videojuegos. En el terreno del diseño, su utilidad es de gran aceptación y es posible desarrollar distintas actividades con este instrumento. La actividad de copiar y pegar, así como las diversas herramientas para distribución en el documento de los elementos diseñados, es posible utilizarla de forma práctica y con mucha velocidad.

En la figura se puede ver un ejercicio de repetición, escala y proporción, el cual puede servir para visualizar diversos aspectos de diseño como repetición, forma y estructura.

En la figura 2 se observa un ejercicio de repetición radial, al cual se puede agregar elementos de gradación y estructurar un

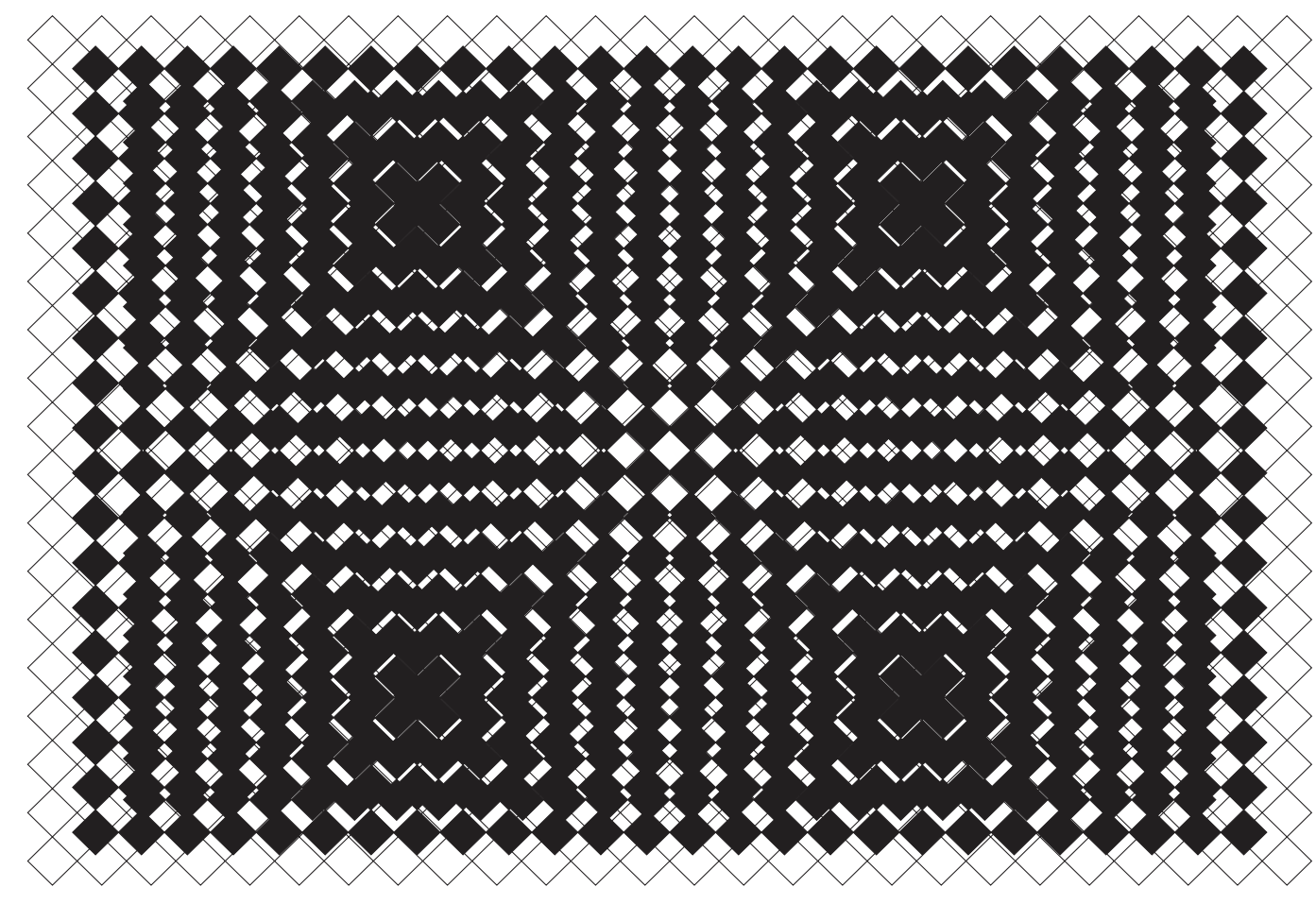

Figura I. Repetición de un módulo de I a l a 454 grados, formando elementos concéntricos en cuatro puntos del diseño. 
diseño en forma circular. De la misma forma es posible realizar cualquier estructura en el diseño con ayuda de estos métodos muy sencillos, pero que permiten de manera muy rápida visualizar los resultados.

También es conveniente revisar la forma de reticular un sustrato en el cual se va a trabajar, de este modo es más sencillo incorporar elementos de estructura en el diseño. En la figura 3 se puede observar de forma clara la estructura de una espiral con base a una retícula.

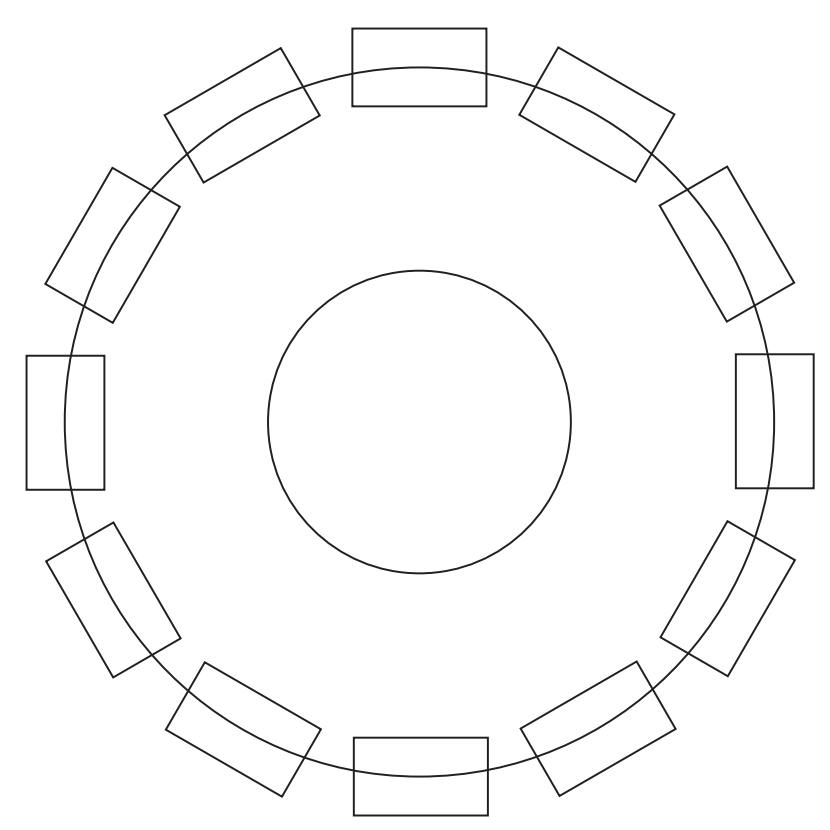

Figura 2. Con un módulo en forma rectangular, se puede crear una repetición alrededor del círculo para dar la forma de un engrane, rueda o cualquier elemento de repetición radial.

Finalmente, estableciendo la conexión entre los conocimientos de diseño modular y la forma de estructurar mediante la ayuda de los programas vectoriales, se puede llegar a realizar ejercicios con módulos y supermódulos que representen estructuras complejas a simple vista, pero que en realidad bajo los mismos pro-

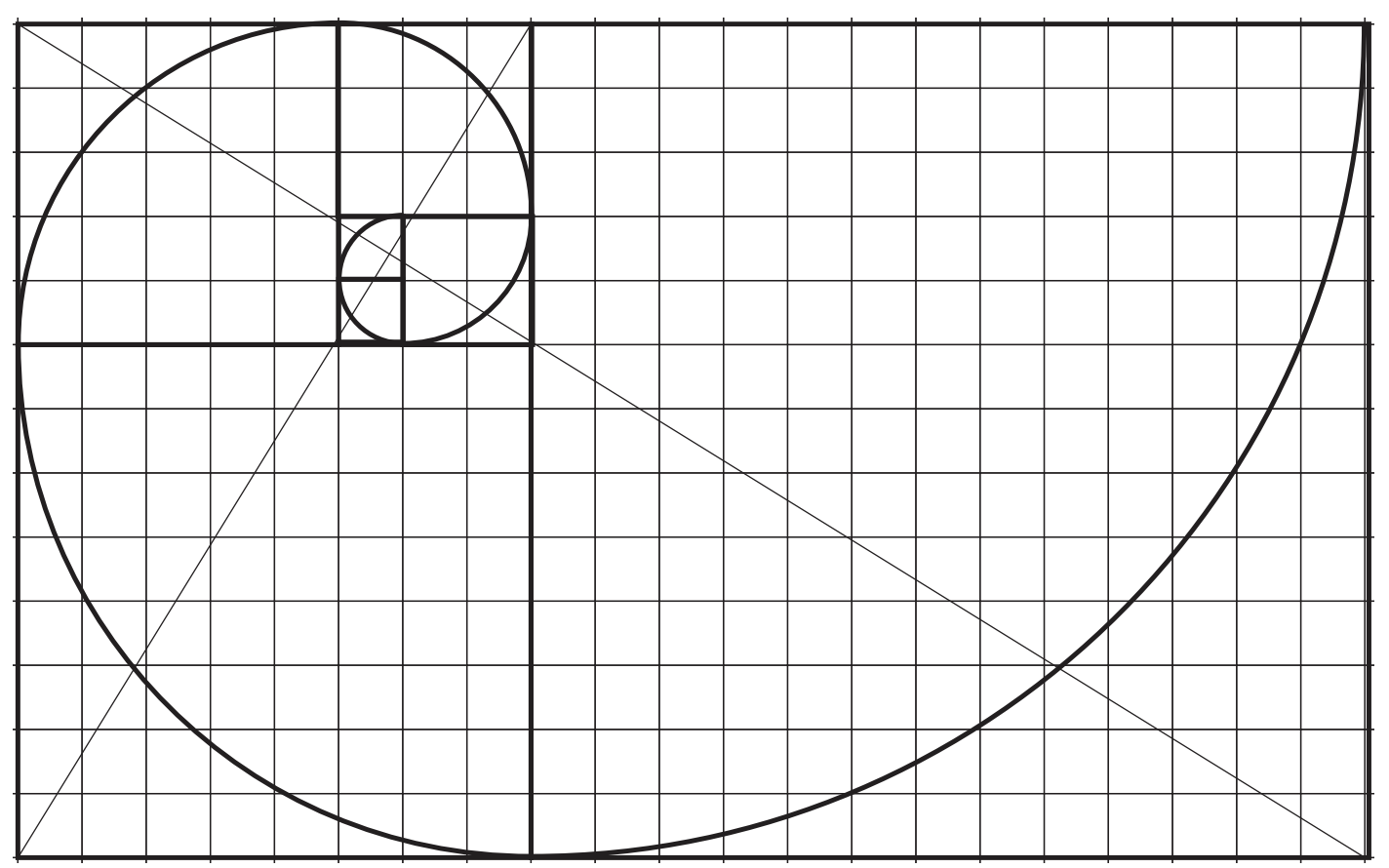

Figura 3. Estructura de espiral basada en una retícula l a l.

cedimientos de repetición llegan a realizarse en cuestión de unos cuantos movimientos, dando lugar a la experimentación y con una gama muy amplia de posibilidades en lapsos de tiempo relativamente cortos.

\section{Conclusiones}

El apoyo de asignaturas mediante el uso de tecnología es una necesidad cada vez más imperante debido a que existen medios que antes era inimaginable utilizarlos. Conforme se vaya obteniendo ventaja al momento de conceptualizar y crear patrones que brinden bases firmes para la estructura del diseño, mayores resultados se obtendrán al momento de crear.

Existen técnicas que dentro de la evolución, han cambiado la forma de aplicarlas o inclusive han desaparecido, sin embargo, van sembrado un precedente dentro de las que se van incorporando, formando un principio que quedará plasmado en la nueva tecnología. Ahora las plumas no son como se inventaron, pero el 

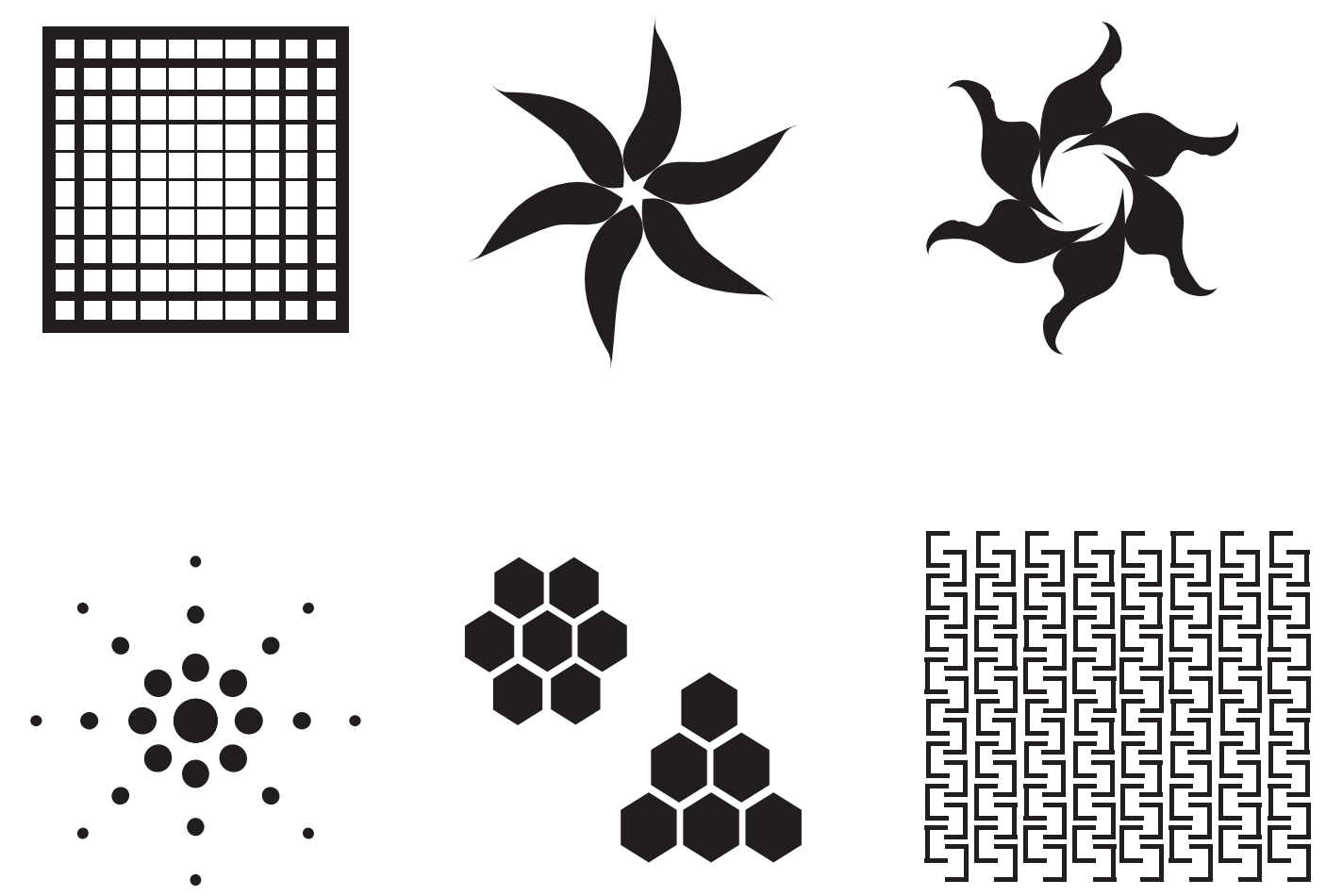

Figura 4. Variedad de gráficos elaborados mediante el proceso de copiar y repetir automáticamente, aplicando principios de diseño modular.

principio permanece arraigado en la tecnología moderna.

Es nuestra misión, como facilitadores y formadores en el proceso educativo, crear nuevos modelos que promuevan cada vez más el desarrollo de los individuos en las sociedades. Esta tarea requiere el apoyo en modelos que permitan incorporar las estructuras mentales que tenía el ser humano antes de la llegada de la computadora y orientar al desarrollo de los pensamientos para utilizar adecuadamente cada medio, sin olvidar que un buen boceto es el principio de un gran diseño.

\section{Referencias Bibliográficas}

Estévez, E. (2002). Estrategias cognitivas. México: Paidós.

Dávalos, H., Maciel, C., \& Orozco, R. (2009). La representación para el diseño en el siglo XXI. México: Ediciones CUAAD.

Guzdial, M. (2000). Soporte tecnológico para el aprendizaje basado en proyectos. Aprendiendo con la tecnología. México: Paidós.

Hoffman, D. (2000). Inteligencia visual. México: Paidós.

Marín, J. (1995). Expresión Gráfica. México: Editorial Trillas.

Meggs, P. (2000). Historia del Diseño Gráfico. México: McGrawHill.

Rivera, L.A. (s.f). Del arte, Fontana y ciertas implicaciones pedagógicas. Recuperado de http://www.mexicanosdisenando. org.mx/articulos.php

Rodríguez, M. (2006). Manual de Creatividad. México: Editorial Trillas.

William, S. (2000). La tecnología y el aprendizaje en las aulas de las escuelas para el pensamiento. México: Paidós. 


\section{El metalenguaje del branding y su aplicación en las ciudades}

\author{
Aurora García García de León
}

Una de las maneras idóneas de introducirnos a los propósitos de este capítulo es explicando las características del título, pues es precisamente en el branding donde se encierra gran parte de los motivos que conducen este trabajo. Un verbo que se podría traducir como "marcaje", pero que se ha adoptado como anglicismo válido para referirnos al acto de etiquetar, proveer algo de sentido, identidad o procedencia.

El nacimiento de lo que hoy se conoce como marca tiene sus inicios en la Segunda Revolución Industrial, que para Bruno Remaury (2004) se le podría denominar igualmente "primera revolución mercantil", fenómeno que se caracteriza por una preocupación esencial: rescatar el más insignificante valor otorgado al objeto producido en serie por la manera en la que se dispone, se muestra, se explica. "En este punto de la 'segunda revolución industrial', el consumo alienado se convierte en un deber para las masas, un deber añadido al de la producción alienada" (Debord, 2007, p. 55).

El branding en un principio consistía en marcar con fuego las reses para diferenciar los rebaños. En el caso de la mercancía, en particular a partir de la Great Exhibition de Londres (I85I), esta se aísla de todo aquello que le caracteriza pero destacando aún su estatus de objeto industrializado. Por lo que, de esta pérdida de autenticidad surgirá la necesidad de restablecer su aura, como lo señala Remaury (2004) retomando a Benjamin (1936). "Lo que diferenció los primeros intentos de imponer marcas de la comercialización corriente fue el hecho de que el mercado se vio inundado con productos fabricados en masa y casi idénticos entre 
sí" (Klein, 2007, p. 36). Ese valor aurático, que se podría comparar con el alma del objeto industrializado, es rescatado con las herramientas que ofrece precisamente el branding, donde el "alma" es esencialmente la marca.

Las primeras manifestaciones del branding como disciplina general surgen aquí, pues la marca aparece representada ya sea implícitamente por la forma del producto, su material o su estilo, o explícitamente haciendo énfasis en su nombre, logotipo o procedencia. Esta lógica de marcar un producto será la misma que seguirán a partir de finales del siglo XX las ciudades (sobre todo las postindustriales), pues para recuperar su "personalidad" -que dentro de esta retórica equivaldría al "alma" de las ciudades-, recurrirán a diversos simbolismos que incluso irán cambiando con el tiempo debido a esa inercia cíclica que tiene el branding como disciplina por renovar sus significados.

Ahora bien, ¿por qué branding y no marketing? En ocasiones suelen utilizarse ambos términos para referirse al mismo fenómeno aplicado a las ciudades. En este capítulo, se propone el branding como el concepto que mejor engloba y define lo que está ocurriendo con los procesos de venta de ciudades: crear diferencias e imaginarios que agilicen el conocimiento que se tiene sobre éstas para su consumo. Un proceso dentro del cual el marketing desempeñaría un papel secundario como herramienta de apoyo que no necesariamente pretende desarrollar una ciudad-marca concreta (García, 2013).

Como se ha señalado, debido a su origen norteamericano a principios del $\mathrm{S}$. $\mathrm{XX}$, se encuentra en el argot del branding una constante referencia anglosajona. A su vez el marketing, al tratarse de una disciplina en constante desarrollo, "se ha caracterizado por múltiples intentos de definición y de determinación de su naturaleza y alcance, lo que ha dado lugar lógicamente a numerosas controversias académicas. En un siglo se ha nutrido de otras disciplinas y ciencias para estructurar su función dentro del marco empresarial como la psicología, sociología, matemáticas y estadísticas" (García, 2010). Al mismo tiempo que éste ha incursionado en nuevos campos que desbordan la comercialización de un producto de consumo como convencionalmente se concebía durante el s. XX.

En el caso de las ciudades, a pesar de que existen destellos de una especie de "proto-branding", no será sino hasta que se haga una aplicación directa en la gestión política y urbana cuando se incorporen estos conceptos que con el tiempo y la práctica han logrado instituirse como disciplina; bautizada como "citybranding", "city marketing", "place branding" e incluso en español se puede llegar a encontrar bajo definiciones como "marketing territorial" o ambos idiomas como "branding de ciudad". La variedad de etiquetas refleja la deuda que desde las teorías urbanas existe para clarificar estos términos, sistematizarlos y así procurar un análisis más riguroso. Pero se debe también a la diversidad de intenciones, pues existen los casos en los cuales se pretende crear una "marca país" o una "marca territorio" que no necesariamente respondería a una sola ciudad.

En el caso de las ciudades marca -sin perjuicio de las referencias bibliográficas que utilizan otros conceptos para representar lo mismo- se ha optado por utilizar el término "branding de ciudad" por ser el branding el concepto que mejor engloba y define lo que está ocurriendo con los procesos de venta de ciudades. A la vez que se ha optado por conservar la palabra en su idioma original debido a su difícil traducción y a que todavía no existe una que lo defina tan bien en nuestro idioma.

Los conceptos que a continuación se definirán se han seleccionado por formar parte del metalenguaje del branding, es decir, aquel lenguaje específico que se utiliza al referirse no al caso de estudio o al objeto de donde proviene el discurso, sino el lenguaje que se refiere al objeto del discurso. Este metalenguaje partirá de un contexto disciplinar general para explicar su función en el mar- 
keting, que para efectos de sistematizar la información dividiremos en: conceptos elementales, por tratarse de elementos básicos que componen a la marca y que pueden ser tanto significante como significado; y conceptos contextuales, que serán aquellos que componen el ambiente en el cual se desarrolle la marca. Para Chías y Xifra (2008) el marketing es la ciencia del proceso de intercambio, que se esfuerza por implantar y mejorar constantemente el equilibrio de valores, donde la marca es un valor de mercado.

\section{Conceptos elementales}

\section{Marca}

La marca será el concepto en torno al cual desarrollaremos los demás elementos. Ya se ha explicado la importancia que en sus orígenes toma el marcar el objeto industrializado para proveerle de sentido, de valor, para indicar su procedencia y diferenciarlo de los demás productos. Para explicar mejor este concepto es pertinente comenzar por una cita de Joan Costa:

Una marca es la señal que deja el acto de marcar, el marcaje de una matriz o un trazo sobre una superficie. (...) La impronta, la huella o el trazo que deja ese objeto, que ha sido preparado para esta función de marcar, es genéricamente una señal. Potencialmente esa señal es significante, pero, si no se conoce el código, no se entiende su significado $y$, por lo tanto, permanece simplemente en estadio de señal -aunque se comprende que es señal "de algo"-. Para quien decodifica esa señal y extrae, o reconoce su significado, esa señal deja de ser "señal de algo"; es signo, porque ya significa una cosa concreta. Es por esta razón que el término "señal" no corresponde al vocabulario de la marca. Las marcas deben significar. No siempre señalar. (Costa, 2004, p. 22).

La marca englobaría su nombre, su simbología, su diseño y significados. Sin embargo habrán discrepancias en cuanto a qué tanto representa o comprende, pues para algunos la marca será solamente el nombre del producto: "No hay que confundirla con la imagen de marca. Una cosa es cómo te llamas (marca) y otra lo que piensan de ti (imagen)" (Ordozgoiti y Pérez, 2003, p. 98), mientras que para otros puede ser su nombre o un símbolo, un diseño, un signo o su combinación.

En lo que la mayoría de la literatura relacionada con el marketing coincidirá es en el objetivo esencial de la marca, que es identificar un producto para diferenciarlo del resto. Este principio básico hará que al aplicarse al caso de las ciudades se recurra a una serie de acciones, que si bien forman parte de las dinámicas de su gestión, al agregarle el componente de la marca muchas de las intervenciones urbanas y los dispositivos de comunicación de los gobiernos locales estarán encaminados en consolidarla.

"El nombre de la marca es la parte de la misma que se puede pronunciar. Y la marca registrada es la marca, o la parte de ella, que se protege legalmente para poder ser usada con carácter exclusivo" (Chías y Xifra, 2008). Un ejemplo de marca registrada podría ser "I love NY", "I'amsterdam" y más recientemente la marca "Barcelona", registrada en 2012 entre múltiples polémicas.

Todas las marcas comerciales son símbolos. Un símbolo es una representación cuyo significado no es directo ni intuitivo, sino que está establecido por una relación cultural que el espectador debe haber aprendido antes para poder descifrarla. La marca ciudad se reconoce por combinar un constructo sociohistórico con la gestión urbana e implementación de símbolos arquitectónicos. Será definida entonces por su nombre y aquellos conceptos inherentes a ella.

\section{Identidad de marca}

El caso de la identidad en este contexto poca relación tendrá con las aportaciones que nos pueden dar disciplinas como la filosofía, la antropología o la sociología sobre la cultura actual, aunque para efectos de posicionar ciudades se suele apelar a este tipo de 
posturas. La identidad visual corporativa (IVC), en el contexto del branding, será la manifestación tangible de la marca.

Así, es patente, en palabras de Costa la "función esencialmente identitaria" que cumplen las marcas desde sus orígenes: en el mundo clásico supone un elemento de localización geográfica de la procedencia, [...] a partir de la revolución industrial, la marca incorpora la función de diferenciar un producto de otros semejantes, básicamente por su representación a través del envase y la asignación de atributos iconográficos distintivos (Martín, 2005, p. 23).

La identidad de marca será, en el caso de las ciudades, un atributo diferenciador que desde su gestión se desea que sea reconocible por el consumidor. Para este caso los dispositivos visuales serán los que hagan el trabajo de proveerle a la ciudad marca de identidad, por medio de la exaltación de valores intrínsecamente asociados a ella, que suelen ser de carácter tangible, como lo urbano o arquitectónico.

\section{Diferenciación}

La marca busca esencialmente diferenciar el producto del resto de su tipo. Por lo cual la diferenciación será, en ocasiones, un "atributo discriminante". De manera que será precisamente la identidad de marca la que haga el trabajo diferenciador. "Un discriminador es un atributo complementario de los motivadores, puede ser emocional, psicológico o sensorial, valores simbólicos como la personalidad de marca o una clase especial de usuario. Se trata de una ventaja diferencial, pues cuando un producto no posee un atributo altamente valorizado por el consumidor y éste no se encuentra en los productos competitivos estamos ante una ventaja diferencial" (Bonta y Farber, 1997).

Este atributo será determinante en la creación de una marca ciudad. Pues encontrar un elemento diferenciador (discriminador o no) que identifique a una ciudad no es tarea fácil. Dicho atributo puede ser de carácter geográfico (clima, playa, paisaje), patrimonial (monumentos, arquitectura, restos arqueológicos), social (hospitalidad, calidad de vida, equipamiento), económico (oportunidades de trabajo, inversiones) que una vez identificado toma una nueva dimensión: un valor.

\section{Valor}

Para la teoría del valor marxista la fuerza de trabajo determina el valor de una mercancía -el plusvalor derivado del plustrabajo- en una fase primitiva de acumulación capitalista (Debord, 2007) y de intercambio de mercancías. Sin embargo en la economía de la segunda mitad del siglo XX, en un contexto postindustrial dicho valor radica en ese "sobreprecio" (Klein, 2007) que el consumidor está dispuesto a pagar por un producto de cierta marca, comparado con uno de igual característica pero sin ese sello.

En el libro Arquitectura de Marcas (Martín, 2005), el valor que genera una marca (brand equity) se define por varios factores, como la veracidad de la descripción del producto, el beneficio emocional, la familiaridad y fidelidad obtenida, la buena reputación e imagen pública y las asociaciones generadas por esta marca.

En el caso de una ciudad ese valor añadido se encuentra en esos atributos diferenciadores que proveen de identidad a la ciudad marca. Como en este caso dicho valor está expuesto a un mercado, la manera más práctica de explicar este fenómeno se encuentra en la evaluación del comportamiento de los consumidores de ciudades, es decir, el mercado turístico.

El valor de marca permite que la referencia en la que aspira convertirse el producto sea ética e irreproducible (Cócola, 20II). De manera que se consolide su valor de uso -que en el caso de las ciudades radicaría en la capacidad de inversión, de atraer turismo, nuevos residentes, etc.- en su imagen para así adquirir ese valor añadido que aumente su valor de cambio. 
Para las ciudades marca, el valor radicará en un conjunto de valores positivos que estén asociados con la ciudad. En muchos de los casos se trata de atributos intrínsecos como el clima, la fauna, los monumentos históricos o algunas tradiciones; mas en otro caso se tratará de valores a desarrollar desde la gestión y las estrategias de branding, como son los valores asociados a la efervescencia cultural, la gastronomía, el diseño, etc.

\section{Imagen}

"La información que se almacena y se asocia a la marca en la memoria define la denominada imagen de marca. Esta imagen como representación mental que los consumidores tienen de la marca a partir de sus características, beneficios, valor, etc., no sólo influye en el conocimiento de la marca, sino también en el grado de afecto y en el comportamiento ante ésta" (Rodríguez, 20II, p. 227).

En este capítulo se hace referencia a la puesta en valor de la imagen de la ciudad. Entendiendo a tal imagen como aquella representación visual en la que se plasman los valores diferenciadores del producto ciudad, que suelen poseer un alto carácter simbólico y cuyo impacto en el público trasciende para así instaurarse como representación mental, que en el caso de una imagen de marca deberá componerse por sus atributos y beneficios.

Pero este renovado carácter simbólico del paisaje funciona no sólo como parte de la promoción de las imágenes de las ciudades sino también manipulando las relaciones con la identidad local (Kearns y Philo, 1993; Murray, 200I). Con ello se incorpora la idea que la construcción de la imagen no sólo tiene fines relacionados con la publicidad y la orientación hacia el consumo externo, sino que también se comporta como una efectiva herramienta de control social convenciendo de la benevolencia de las nuevas políticas urbanas en el proceso de transformación de la ciudad (Armas, 2007)

\section{Logotipo}

Es la identidad visual de la marca por antonomasia. Marca gráfica de un producto o servicio, que en la teoría del diseño se le conoce como signo marcario. Su función es resumir en una forma específica a la marca y fusionar marca y nombre, convertir ambos conceptos en sinónimos. "El logotipo es el símbolo gráfico que se utiliza para distinguir una marca. Por lo general, el logotipo suele ser una combinación múltiple del nombre o parte del mismo con otros elementos gráficos, como símbolos o emblemas, con un grafismo específico y unos colores distintivos" (Rodríguez, 20Il, p. 227).

En un mercado tradicional de productos de consumo el logotipo suele ser de suma importancia, mientras que en el caso de las ciudades su desarrollo se ha difundido más recientemente, particularmente a partir del siglo XXI con más fuerza. Además, debido a la volatilidad de las campañas de ciudad (cuyo objetivo suele ser principalmente turístico y político), las ciudades marca han optado por renovar continuamente sus logotipos y eslóganes con la intención de refrescar contenidos, en una apuesta por el factor novedad.

En la actualidad los logos (cristalización icónica de la marca y del valor de marca) pueden sumarse al conjunto de elementos identitarios de una ciudad o región; al igual que en la consolidación de las nacionalidades decimonónicas las banderas, los escudos e himnos identificaban y posicionaban a los pueblos en momentos de su construcción estadual. (Fernández y Paz, 2005).

\section{Signo}

Como se ha explicado en palabras de Joan Costa, una señal decodificada es un signo pues se reconoce en él su significado. Las marcas no solo señalan, ya que deben significar y será el signo el que haga ese trabajo. 
El significado y el significante, son, dentro de la terminología de Saussure, los componentes del signo. (...) Signo, en efecto, se inserta, según el arbitrio de los autores, en una serie de términos afines y desemejantes; señal, indicio, icono, símbolo, alegoría son los principales rivales del signo. Establezcamos primero el elemento común a todos estos términos: todos remiten necesariamente a una relación entre dos relata (Barthes, 1990, p. 38).

Roland Barthes construye un cuadro con variaciones de sentido de estos conceptos, a partir de las interpretaciones de Hegel, Peirce, Jung y Wallon, con las cuales se pueden comprender sus diferencias. Si se reinterpretan las posturas de estos autores se vera que, a diferencia de las señales, el símbolo y el signo poseen una representación psíquica. Sin embargo el signo tiene solo la facultad de representar (ser denotativo). En una marca ciudad se pueden incorporar signos como, por ejemplo una cruz, que independientemente de su contexto, de su color o de las dimensiones de sus componentes representará invariablemente la tradición religiosa de cualquier pueblo. La única facultad que tiene el diseño de un signo es su adecuación en el relato de las marcas ciudad.

La significación es un proceso subyacente en toda comunicación. El signo se define como una entidad de dos caras íntimamente unidas: el significante (aspecto material del signo) y el significado (concepto). Por tanto, la asociación entre cosas de órdenes diferentes, significante y significado, producirá el signo (Zunzunegui, 1989, p. 59).

\section{Símbolo}

La representación psíquica que tiene el símbolo tiene el atributo de poder ser analógica, a diferencia del signo: " (...) en el símbolo la representación es analógica e inadecuada (el cristianismo 'desborda' la cruz), frente al signo, en el cual la relación es inmotivada y exacta (no hay analogía entre la palabra buey y la imagen buey, que queda perfectamente cubierta por su relatum)" (Barthes, 1990, p. 38).

La simbología es uno de los elementos más importantes del desarrollo de una marca, pues provee de significado a la marca y su tratamiento posibilita una interpretación que puede ser unívoca o puede ser múltiple, de enfoques diversos y perspectivas varias. "Los símbolos son el verdadero quid de las culturas, tanto si se presentan de forma escrita, verbal, auditiva como si lo hacen a través de una pintura. Son los diversos medios a través de los cuales los humanos se comunican, celebran y protegen sus creencias y valores" (Atkin, 2008, p. 135).

Concretamente, en la tradición comunicativa de las ciudades se toman como símbolos sus monumentos y su arquitectura. El valor simbólico de estos estará en función no solo de las campañas oficiales de cada ciudad, sino en los imaginarios que de esta se deriven, el valor que ciertas imágenes urbanas de la ciudad adquieran en la población y cómo se retienen o asimilan.

\section{Eslogan}

La palabra eslogan proviene del inglés slogan, utilizado originalmente en gaélico escocés para componer la frase sluagh-ghairm, que significa grito de guerra. Por lo cual la referencia que se hace al grito, tiene relación con la capacidad de resumir en una frase corta -como en un grito- una idea. "El concepto creativo de la marca muchas veces está sintetizado en una frase que lo representa. Así como el logotipo o isotipo constituye la síntesis gráfica de una marca, el slogan es su símil literario" (Bonta y Farber, 1997, p. 126).

Los eslóganes son el relato breve de la marca y para su desarrollo se suelen concentrar en él diversos valores, según sea el caso del producto. Al igual que el logotipo, el eslogan destacará en una frase un valor diferenciador, simbolismos que engloben y definan el producto. 
"El eslogan ha evolucionado. Y de grito de guerra ha pasado a significar, primero, consigna política y, luego, reclamo comercial. Sus funciones son expresar la ventaja principal del producto, diferenciarlo y atraer la atención del destinatario en medio de la jungla comunicativa. Y para conseguirlo de manera eficaz, todo slogan debe ser breve, simple, conciso, brillante y recordable" (Rey, 1997, p. 99).

Como por ejemplo los casos de los eslóganes "Iamsterdam" (Yo soy Ámsterdam) y "BeBerlin" (Sé Berlín) para sugerir que las individualidades ciudadanas pueden definir toda una ciudad. Más recurrentes serán los afectos hacia la ciudad tales son los casos de eslóganes como "Love Barrow", "Amor por Bogotá", "Virginia is for lovers" y "Hermosillo te quiero".

\section{Conceptos contextuales \\ 10. Imaginario}

La idea brusca y determinista de que en la ciudad lo que importa es lo "real", lo "económico", lo "social", ha dejado por fuera otras consideraciones más abstractas pero no menos reales: podemos decir que lo real de una ciudad no es sólo su economía, su planificación física o sus conflictos sociales, sino también las imágenes imaginadas construidas a partir de tales fenómenos, y también las imaginaciones construidas por fuera de ellos, como ejercicio confabulatorio, en calidad de representación de sus espacios y de sus escrituras. (Silva, 2006, p. 146)

El imaginario es ingrediente imprescindible de la creación de una ciudad marca. Materia prima proveedora de significados y a su vez generadora de otros nuevos. Pero las imágenes mentales derivadas de los dispositivos del marketing como los signos, logotipos, eslóganes, simbologías... ¿Acaso serán generadoras de imaginarios?
Nada hace demostrable que los lenguajes que emplea el urbanícola sean variaciones sumisas del sistema que un grupo dominante impone a través de su control sobre la producción de formas y símbolos urbanos. (...) Tampoco los imaginarios urbanos tienen por qué identificarse -aunque se identifiquen sistemáticamente-con la imagen que de una determinada ciudad se pretende dar desde las campañas oficiales o comerciales de promoción, destinadas a turistas, inversores o a los propios ciudadanos. Ese tipo de imaginarios usurpados destinados a la propaganda o a la publicidad se basan en la simplicidad y son de hecho imaginarios caricaturescos, hechos de tópicos y clichés orientados a convertir a sus destinatarios en súbditos dóciles o en consumidores dependientes (Delgado, 2007, p. 184)

En los relatos de las ciudades pululan múltiples imaginarios urbanos, sociales, culturales. Sería absurdo negar su participación en los dispositivos publicitarios de las administraciones locales o las promociones turísticas. Lo importante aquí será identificar quién determina la materia prima para la construcción de una marca ciudad e incluso para su mitificación serán los imaginarios colectivos. Sin embargo, una buena forma de evaluar el efecto que el branding de ciudad tiene en el mercado turístico, en la ciudadanía y en los diversos receptores, será precisamente analizando los imaginarios que se deriven de su implementación en la sociedad.

\section{Co-branding (Brand Partnership)}

Una co-marca "es el resultado que se produce cuando marcas de distintas organizaciones se unen para crear una oferta en la cual cada una desempeña un papel conductor" (Martin, 2005, p. 3I). En el co-branding de una ciudad diversas marcas se suman con el fin de ser asociadas con su identidad. Están los ejemplos de marcas que agregan el nombre de la ciudad a su marca, como L'oreal Paris, Kenneth Cole New York o Custo Barcelona. 
Mientras que dentro del co-branding se encuentran también las submarcas, que en el caso de una ciudad habrá que ser cuidadosos de no reducir la marca ciudad a un solo aspecto, pues aunque se debe trabajar en la diferenciación -lo que solo ella es capaz de ofrecer-, la marca deberá formularse a partir de su ADN con los múltiples valores que contiene.

Ese será uno de los elementos a analizar en el caso de Barcelona, pues existen submarcas potentes, como Fútbol Club Barcelona, o la misma marca Gaudí, que han llegado a definir a la ciudad por encima de cualquier otra característica diferenciadora.

\section{Marketing}

El concepto de "marketing" surge como disciplina en la economía norteamericana a principios del siglo XX (García, 20I0). El Diccionario de marketing y publicidad define este concepto como:

Política, mezcla planificada de estrategias que, partiendo del conocimiento cualitativo y cuantitativo del entorno y del mercado y de sus tendencias, se ocupa de la concepción, desarrollo, planificación, difusión y comercialización de marcas, productos y servicios, que satisfagan las expectativas de la demanda, logrando resultados rentables para la empresa y organización interesada. (Iniesta, 2004).

La literatura que plantea el marketing enfocado a la ciudad es relativamente nueva. A finales del siglo XX comienzan a editarse publicaciones relacionadas con el "city marketing" y no es sino hasta los primeros años del siglo XXI que se diversifica la bibliografía y sus enfoques. El marketing de ciudades es ahora abordado como fenómeno no solamente por la mercadotecnia y la economía; sino que ahora es estudiado desde la sociología, la antropología y el urbanismo. Será definido como el proceso de desarrollo y comunicación de la oferta urbana en sus intercambios de comercialización con las demandas' de los diversos públicos e instituciones.

El marketing local es relativamente nuevo, y tuvo su bienvenida teórica con Marketing Places (1993) y The Marketing of Nations (1997). Después, mis colaboradores y yo preparamos Marketing Placers Europe (1999) y Marketing Asian Places (2001). Antes de eso, algunos teóricos del marketing trabajaron en estudios «en el país de origen» diseñados para medir el efecto de la imagen de un país en las percepciones y preferencias acerca de un producto o una marca (Kotler, 2005, p. I09)

El marketing aplicado a las ciudades se ha venido a instalar en el siglo XXI dentro de las lógicas del branding como herramienta para promover y vender los atributos asociados a la marca y proveerles de un valor comercial en el mercado de ciudades.

\section{Mercado}

El mercado se puede definir como el contexto en el cual se efectúa una "relación de intercambio", el cual estará compuesto por variables que determinarán a cada uno de diversas maneras. "Conjunto de compradores que pueden agruparse por disponer de los recursos económicos necesarios y compartir una necesidad o preferencia que la empresa puede y quiere satisfacer con un determinado producto o servicio" (Ordozgoiti y Pérez, 2003, p. 22).

Puede dividirse por el tipo de demanda, por cantidad de oferta y por la categoría del producto o servicio ofrecido. En el caso de

I «La demanda es una formulación expresa de un deseo, que está condicionada por los recursos disponibles del individuo o entidad demandante y por los estímulos del marketing recibidos» (López-Pinto, Mas y Viscarri, 2008, p. 18). 
las ciudades un mercado serían los "consumidores de ciudades", entendiendo por esto al turismo urbano. Mientras que otro grupo importante del mercado del branding de ciudad, será, como se ha mencionado ya, las personas que residen en ella.

\section{Segmentos (Target market)}

Segmentación es el proceso por medio del cual se divide el mercado en porciones menores de acuerdo con una determinada característica, que le sea de utilidad a la empresa para cumplir con sus planes. Al segmentar el mercado se pueden maximizar los esfuerzos de marketing en el segmento elegido y se facilita su conocimiento (Bonta y Farber, 1997, p. 30).

Por lo cual el segmento será aquella parte homogénea del mercado que comparte variables en particular que la diferencian de otros segmentos. En el caso de las ciudades un segmento podría ser el mercado gastronómico, el portuario o el de los deportes extremos.

Los segmentos pueden considerar variables como por ejemplo la edad del consumidor, de manera que una ciudad marca puede estar orientada al mercado joven, al femenino o al de personas en edad de jubilación. Así mismo se puede segmentar de acuerdo al tipo de turismo, como puede ser el lowcost, el mercado asiático o el turismo de lujo.

Según se explica en Los pilares del marketing, los beneficios de segmentar el mercado son: "Incrementa la lealtad producto/ marca; Capta clientes con más facilidad; Facilita el análisis de la competencia; Ayuda a comparar prioridades; Ayuda a descubrir oportunidades; El equipo de ventajas emplea sus conocimientos para orientar mejor el presupuesto total de marketing" (López-Pinto, Mas y Viscarri, 2008, p. 42).

\section{Posicionamiento}

El posicionamiento se logra al segmentar el mercado y convertirse en oferta líder en ese segmento. Si una ciudad marca opta por un segmento del mercado que busque el ocio nocturno, esta logrará posicionarse no sólo ofreciendo opciones de diversión nocturna sino al convertirse en la opción favorita del público de ese mercado. "Posicionar un producto, es definir su grupo objetivo y el beneficio básico. Es decir, posicionar es seleccionar una clientela determinada y decidir cuál va a ser la razón por la que deben preferir nuestro producto a sus competidores" (Ordozgoiti y Pérez, 2003, p. 65).

\section{Estrategia}

Patrón fundamental de los objetivos actuales y futuros, aplicación de los recursos e interacciones de una organización con los mercados, los competidores y otros factores del entorno. (..) Una buena estrategia debería especificar qué se tiene que llevar a cabo, hacia qué productos y mercados hay que orientarse, y qué recursos $y$ actividades se asignarán a cada producto y mercado, teniendo en cuenta las oportunidades y amenazas, para aumentar la ventaja competitiva (Chías y Xifra, 2008, p. 79)

Para estos autores la segmentación y el posicionamiento son fundamentales para evaluar la coherencia y cohesión de toda acción del marketing. Una defición de estrategia puede ser:

visión global y a largo plazo de un negocio. Deviene de un conjunto organizado de acciones tácticas encaminadas hacia los objetivos propuestos. La previsión del futuro se plasma en una planificación a corto, medio y largo plazo. Las cuestiones a resolver, siguiendo un orden mental estratégico, son las siguientes: ¿A dónde queremos dirigirnos? ¿Dónde estamos? Y ¿Cómo podemos llegar? (Iniesta, 2004). 
Las estrategias tienen múltiples finalidades, en el caso del branding de ciudad entre las más utilizadas está la estrategia competitiva (de posicionamiento), la estrategia de sensibilización rápida por choque (de difusión masiva por medio de los mass media), y la estrategia de expansión geográfica, es decir, llegar a más público.

En el branding de ciudad las estrategias cobran un sentido sumamente importante. Pues al tratarse de una cuestión a la vez que territorial también social; las estrategias contemplarán desde campañas precisas de concienciación ciudadana hasta intervenciones urbanas de gran magnitud. Para explicar en qué consisten estas estrategias en la gestión de ciudades se le dedicará un espacio especial en esta investigación, pues las propuestas son diversas y los casos de estudio muestran ciertas constantes pero también diferentes acciones de acuerdo con el tipo de ciudad.

\section{Campaña}

Como se ha hecho mención, las estrategias de marketing contemplan diversas acciones, una de las más socorridas por este caso de estudio serán las campañas. Según el Diccionario de marketing y publicidad, una campaña está conformada por el "conjunto de algunas de las acciones de que se compone el plan de marketing".

Estas suelen englobar un objetivo primordial dentro de un plan de objetivos generales, "se desarrollan en un período de tiempo determinado durante el cual está programada la inserción de anuncios en distintos medios de comunicación, seleccionados en función de los objetivos de la campaña, audiencia de los medios y coste de lasinserciones" (López-Pinto, Masy Viscarri, 2008, p. 262).

Este término suele asociarse con la política, por ser la campaña una de las herramientas de los partidos políticos para llegar a la ciudadanía y exponerle sus proyectos. Sin embargo, aquí se identificarán las campañas relacionadas con el fomento al comportamiento cívico, a la exaltación de identidades locales y a la búsqueda de objetivos comunes entre la gestión municipal y la ciudadanía.

\section{Publicidad}

Instrumento de promoción de un producto o de una idea a través de un medio de comunicación, como puede ser la prensa escrita, radio, televisión y correo directo o e-mail. Los objetivos básicos de la publicidad son: informar sobre el producto y sus virtudes, persuadir al consumidor a decidirse por un producto frente a los de la competencia y recordar en el caso de productos consolidados o estacionales (López-Pinto, Mas y Viscarri, 2008).

Este recorrido por el metalenguaje del branding da pie para abordar las diversas estrategias que se han teorizado sobre esta disciplina aplicada a la ciudad por medio de esquemas o a través del análisis de casos de éxito que se han ido consolidando a través del tiempo y cuya sustentabilidad se basaría en el balance entre turismo e inversión de calidad y el desarrollo social integral de la ciudadanía (reproducción social). Tarea nada fácil, debido al gran número de variables a considerar y a la complejidad que representa la gestión de ciudad dada la cantidad de factores que intervienen en ella.

\section{La aplicación del branding en las ciudades}

El branding de ciudad es sin duda una suma de estrategias de gestión de la ciudad global. No se puede entender si no es a partir de la asimilación de los cambios en la estructura económica y política que han tenido consecuencias directas en el modo de entender la ciudad. Simon Anholt, considerado el padre del "place branding" propone esta disciplina desde el ámbito "del lugar", ya que desarrolla estrategias tanto para ciudades, como para regiones e incluso países. 
Anholt es conocido por frases como "actions speak louder than words" y "don't talk unless you have something to say", es decir, el place branding no se trata solo de comunicar sino de implementar acciones en la ciudad: invertir en productos locales, servicios turísticos, infraestructura, educación, deportes, salud y patrimonio cultural que "hablen" por la marca. "Anholt desarrolló en el año 2005 un modelo hexagonal para la marca país en un polígono formado por seis términos clave: turismo, exportaciones, política externa e interna, inversión e inmigración, cultura y patrimonio, gente" (Correa, 2010).

La razón de ser del branding de ciudad es sin duda la competencia interurbana, pues de otra manera la necesidad de destacar por medio de la diferenciación o el valor añadido sería un absurdo al no existir una razón o competencia concreta contra la cual compararse. Una de las herramientas utilizadas para medir el impacto de las marcas es el "Benchmark", que significa hacer una comparativa. Para algunas agencias la marca ciudad equivale a la reputación: la imagen o percepción que se tiene sobre ella. La marca ciudad es una promesa de valor que busca posicionarse para así destacar en su ámbito, con la particularidad de que para tangibilizar sus promesas, el urbanismo y la arquitectura desempeñarán un papel fundamental.

Para Jordi Tresserras, la mayoría de las veces el principal objetivo de las campañas de marketing de ciudades viene a ser la mejora de la calidad de vida. Sin embargo, el marketing per se no siempre asegura este resultado, sobre todo cuando busca el beneficio económico en detrimento de las necesidades ciudadanas. "El marketing urbano o city marketing es un concepto todavía no muy asentado teóricamente en las disciplinas que lo estudian y que adquiere diferentes denominaciones: place marketing, urban marketing, etc." (Tresserras, 2004, p. 80). La diferenciación que se hace con el marketing es porque este es mucho más tradicional (es decir, trata a la ciudad como objeto de consumo), por medio de la segmentación, la focalización y el posicionamiento orientado más hacia la publicidad y el desarrollo del proyecto. Lo que caracteriza a esta disciplina es que los "place marketers" a menudo buscan promover un lugar desde una sola perspectiva, con un enfoque objetivo de mercado.

Las estrategias de branding de ciudad contemplan el estudio y/o creación una "identidad del lugar" no reproducible en otras ciudades, lo cual, en teoría, la hará única y creará un vínculo emocional con la ciudad; así como una conciencia colectiva y de participación ciudadana. También, como se ha señalado, incluye el diseño de un logotipo y/o eslogan de la ciudad, que en algunos casos forman parte de campañas específicas; además de la gestión y planeación urbana que contempla como prioridad la reapropiación de significados en la arquitectura patrimonial y la proyección de arquitectura icónica que represente a la ciudad.

Cabe señalar que dicha estrategia nace de inquietudes de carácter político y económico, pues generalmente el fin último es atraer capital, razón por la cual es habitual que este tipo de proyectos se lleven a cabo bajo la tutela de autoridades municipales y/o nacionales en coordinación con la iniciativa privada para proyectar la competitividad de la ciudad marca en diferentes ámbitos. Por lo que se está hablando de inversiones importantes que conllevan objetivos específicos para los interesados: atraer la inversión extranjera, establecerla como destino turístico, proyectarla como nuevo centro de negocios, hacerla sede de algún evento importante y en algunos casos fomentar la atracción de nuevos residentes.

Existe una diversidad de literatura reciente sobre el branding de ciudad en donde se analiza cómo se ha replanteado el modo de hacer ciudad y cómo esto ha llegado a incorporarse a las agendas políticas de muchas administraciones locales. Los expertos en branding de ciudad ofrecen diversos esquemas de planificación estratégica. Sabaté (20I0) define el concepto branding apli- 
cado a la ciudad como "todas las acciones orientadas a construir o gestionar una ciudad como marca. Con el objetivo de una personalidad propia que la diferencie del resto de ciudades". Martínez (2006), por ejemplo, divide su propuesta de plan estratégico en tres proyectos: el económico (servicios, construcción, agricultura, empleo, turismo), el social (bienestar, educación, cultura, deportes, sanidad) y el territorial (arquitectura, infraestructura, urbanismo, medio ambiente, vivienda). Que va dirigido hacia ambos tipos de mercado (habitantes y visitantes en potencia).

Uno de los expertos que mayor difusión le ha dado al branding de ciudad y que tiene una participación importante para su implementación en países pioneros como España ha sido Hermenegildo Seisdedos, para quien el city branding "es más que un juego de palabras" y "reside en las antípodas del vigente mimetismo urbano" (Seisdedos, 2010). Una de sus propuestas consiste en combinar el city marketing con la planeación estratégica, donde el primero englobaría lo intangible (valores, imagen, sociedad y cultura) y lo segundo lo tangible (diseño, servicios, infraestructura). Además de considerar la identidad colectiva como un factor de creación de imagen de ciudad, que a su vez resaltará su personalidad y le aportará ventajas competitivas. Lo que contempla una dualidad como constante en los diversos análisis que se han hecho sobre el branding de ciudad: la identidad urbana (campaña interna de ciudad) y la imagen de ciudad (proyección hacia el exterior).

Otra aportación será la de Gabriel Fernández y Sergio Paz que desde su perspectiva señalan:

Una combinación de recursos tangibles e intangibles destinados a mejorar la imagen de la ciudad; un recurso de competitividad para la ciudad; un diseño a partir de los valores, creencias y cultura que transmite a los destinatarios un factor no reproducible en otras ciudades; una herramienta de construcción de una cultu- ra ciudadana participativa; un producto derivado de la aplicación sistemática de métodos destinados a la generación de campos creativos sinérgicos para el diseño de signos de identidad urbana (Fernández y Paz, 2005)

Así que, en ningún momento se plantea la marca ciudad como abstracción vacía de contenidos, sino que de alguna manera no se concibe como ciudad competitiva hasta que es primeramente "vendida" a su ciudadanía, que para implicarse en el proyecto de ciudad marca deberá primero cubrir sus necesidades básicas. Norberto Muñiz desglosa su estrategia en tres fases para un proceso integral de transformación y promoción territorial:

Dirección estratégica, gestión o planificación: Política de buena gobernanza y planificación de un territorio institucional, en red entre las administraciones públicas y la sociedad civil (empresas y otras instituciones y colectivos), para mejorar posiciones competitivas. Urbanismo, infraestructuras, fomentar valores.

Marketing: proceso de desarrollo y comunicación de las ofertas urbanas, regionales o nacionales, en sus intercambios de comercialización (vender, promover) con las demandas de los diversos públicos e instituciones.

Branding: fase más o menos avanzada de creación de marca de una ciudad, una región o un país, como 'productos' susceptibles de ser objetos de consumo (ser destino de viajes, mejorar imagen, generar notoriedad, atraer inversiones, potenciar exportaciones, etc.), de acuerdo con su identidad. Generación de una marca territorial: place branding (Muñiz, 20I0).

Como se veía en el "metalenguaje del branding", este concepto aplicado a un producto cualquiera comercializable tiende a 
interpretarse como un proceso de invención, de creación de algo previamente inexistente. En cambio en el caso de las ciudades una de las perspectivas acertadas es la de rediseñar la ciudad.

Para Toni Puig "es el concepto actual para debatir, trabajar y gestionar las ciudades que apuestan por más y diferente ciudad" (Puig, 2009). Sugiere, además, que dicha estrategia incluya conceptos como la comunicación, confianza, motivación, mestizaje, rediseño, implicación y competencia. Opta por utilizar rediseño frente a citymarketing por parecerle más contundente y adecuado a nuestro lenguaje. La marca es lo que se quiere ser como ciudad, por lo que se centra más en explicar en qué se basa el rediseño y por qué lo necesitan las ciudades para consolidarse tanto entre sus habitantes como en el mercado global.

Existen ciudades que dan nombre a universos imaginarios potentes, estables y relativamente universales. Son singulares, notorias y prestigiosas: París, Nueva York, Londres, Berlín, Venecia, Buenos Aires, Río de Janeiro, La Habana, etc. Cuando una marca de perfumes o de ropa aclara bajo su logotipo "París-Londres-New York", no está haciendo una referencia toponímica: se está respaldando la importancia de esas tres ciudades. Está diciendo: "Estamos donde hay que estar cuando se tiene calidad" (Chaves, 20ll, p. 280).

Según la opinión de algunos autores, a un nivel territorial el marketing cobra mayor importancia que el branding por tratarse de una cuestión estratégica que engloba cuestiones mucho más tangibles como lo es la infraestructura y las redes de comunicación. Mientras que los resultados de la aplicación parcial o incompleta de las estrategias de branding suelen ser de un elevado nivel de intangibilidad. Un atributo que, como veremos, radicará en todos aquellos valores que cobren un significado independientemente de su materialidad.
Lo cual ha dado cabida a un elevado número de críticas sobre la utilización deliberada de estos dispositivos en los últimos años. "El marketing como herramienta fundamental para la gestión de su imagen, un marketing cada vez menos centrado en los elementos tangibles o de infraestructuras y más focalizado en lo intangible, en los valores, en la creatividad" (Baladrón, Martínez y Pacheco, 2007, p.14).

Si acaso la base para hablar de los valores culturales intangibles sean los criterios de la UNESCO para nombrar patrimonio "inmaterial" de la humanidad, que no es otra cosa que la traducción de la palabra en inglés "intangible". Aún con esta referencia, en ocasiones encontraremos valores mucho menos regulados que podrán girar por ejemplo, en torno a la figura de un artista que ya ha muerto, aunque no sea precisamente a su obra. Mucho de la intangibilidad a la que harán referencia algunas de las fuentes consultadas radican en ese halo de "valor simbólico".

Uno de los artífices predilectos de estas estrategias tan difundidas es la conservación y/o recuperación del patrimonio arquitectónico como una manera de generar espacios de interacción simbólica que deberá ser compartida entre los ciudadanos y proyectada al visitante, ya sea que se trate de restos arqueológicos, edificios protegidos o monumentos representativos que hayan adquirido algún valor simbólico colectivo. Pues para el branding de ciudades ese valor añadido radicaría en la autoestima y complicidad ciudadana y en los significados que se emanan de su imagen ante el mundo.

Entre las múltiples agencias que se reproducen cada vez más para trabajar en el relanzamiento de ciudades está Young\&Rubicam, con equipos que trabajan a nivel internacional y que tienen oficinas en las principales ciudades alrededor del mundo. En una de sus apariciones en las que explican su manera de trabajar, dieron a conocer una especie de decálogo sobre el branding de ciudad: I. Hazla fácil de filmar, 2. Elige bien tus íconos, 
3. Haz que sepa bien, 4.-Habla un idioma que todos puedan entender, 5. Asegúrate de tener un buen aeropuerto, 6. Ofrece qué hacer (experiencias), 7. Mantén al visitante seguro, 8. Mantenla al día, actualízate, 9. Nunca debes proyectar demasiados íconos, 10. Realiza una serie de TV2.

Un aspecto, a propósito de este decálogo, que de alguna manera desprestigia y pone en duda la seriedad del branding de ciudad, es que algunos de estos "pasos a seguir" para colocar a la ciudad en una posición que le permita competir y destacar en el mercado de ciudades son malinterpretados como "recetas". Cuando se trata de un proceso muy complejo que en ninguno de los casos puede reproducirse de una ciudad a otra. Sin embargo, interpretar las estrategias como un recetario no será lo único que cause escepticismo por el branding. También lo serán los casos que se quieran legitimar a partir de un repetido discurso identitario que se apoye ya sea en la arquitectura patrimonial o en la creación de nuevas arquitecturas singulares. Una de las acciones más socorridas es la construcción de la tan afamada "arquitectura milagrosa" cuya máxima representación -y aquí surge de nuevola encarnaría el Guggenheim de Bilbao (1997), que emerge en un contexto de homogeneización de elementos arquitectónicos promocionales y edificios "de autor", y que además desencadenará una obsesión por los edificios emblemáticos de nuevo cuño.

Por último, cabe mencionar las críticas hechas hacia el marketing de ciudades concebido erróneamente o con un enfoque desequilibrado, como por ejemplo, los que se desarrollan con una obvia orientación hacia el turismo, en detrimento de los propios ciudadanos. Así como hacia las campañas publicitarias (la fórmula logo+eslogan) con cargas retóricas o vacías de contenido

2 Algunas reglas de YyR sobre el branding de una ciudad en: Curso City Branding (CUIMPB-Centre Ernest Lluch). Barcelona, 27 y 28 de septiembre de 2010 que repiten fórmulas no solo en la manera de actuar en la ciudad sino en el lenguaje visual para proyectar sus valores, aunque estos sean totalmente diferentes. La construcción de una ciudad marca no conlleva volcar toda la actividad y las acciones desde la gestión para la proyección y el reconocimiento. La marca es un resultado y lógicamente las ciudades con un camino recorrido, en cuanto a mejoras integrales de la ciudad, tienen ventajas importantes a la hora de querer desarrollar una identidad de marca. 


\section{Referencias bibliográficas}

Armas, A. (2007, marzo). En torno a la mercadotecnia urbana: reorganización y reimaginación de la ciudad. Biblio 3W Revista Bibliográfica de Geografía y Ciencias Sociales, 12(7I2). Recuperado de http://www.ub.es/geocrit/b3w-712.htm

Atkin, D. (2008). El secreto de las marcas. Barcelona: Editorial Robin Book.

Baladrón, A.J., Martínez, E., y Pacheco, M. (2007). Publicidad y ciudad. La comunicación publicitaria y lo urbano: perspectivas y aportaciones. Sevilla: Comunicación Social Ediciones y Publicaciones.

Barthes, R. (1990). La aventura semiológica. Barcelona: Paidós.

Bonta, P., \& Farber, M. (1997). 199 preguntas sobre marketing y publicidad. España: Norma.

Chaves, N. (20II). Del modelo a la marca. Lo real y lo imaginario en la gestión urbana. En J.Montaner, F. Álvarez, \& Z. Muxí(Eds.). Archivo crítico modelo Barcelona 1973-2004 (pp. 276-283). Barcelona: Universitat Politécnica de Catalunya. Ajuntament de Barcelona.

Chías, J., \& Xifra, J. (2008). Las relaciones públicas y el márqueting. Barcelona: Editorial UOC.

Cócola, A. (20II). El Barrio Gótico de Barcelona. Planificación del pasado e imagen de marca. España: Ediciones Madroño.

Correa, A. (2010). Ciudades, turismo y cultura. Nuevas perspectivas para el desarrollo equitativo de las ciudades. Tucumán: La crujía ediciones.
Costa, J. (2004). La imagen de marca: un fenómeno social. España: Paidós lbérica.

Debord, G. (2007). La sociedad del espectáculo. Valencia: PreTextos.

Delgado, M. (2007) Ciudadano, mitodano. En A. Silva et al (Eds.) Imaginarios urbanos en América Latina: urbanismos ciudadanos. (pp. 179-187). Barcelona: Fundació Antoni Tàpies.

Fernández, G., y Paz, S. (2005, Agosto). Más allá del marketing de ciudades: hacia una política pública de diseño y gestión de los signos de identificación de ciudad. Scripta Nova. Revista electrónica de geografía y ciencias sociales, 9(194). Recuperado de http://www.ub.es/geocrit/sn/sn-194-94.htm

García García de León, A. (2013). El branding de ciudad: la promoción del modelo Barcelona y su proyección como marca. (Tesis inédita de Doctorado). Universidad Politécnica de Catalunya, Barcelona. http://www.tesisenred.net/handle/I0803//295/7

García, I. (2010, marzo). Origen y evolución del marketing como disciplina científica. Contribuciones a la Economía. Recuperado de http://www.eumed.net/ce/2010a/igr2.htm

Iniesta, L. (2004). Diccionario de marketing y publicidad. Barcelona: Ediciones Gestión 2000.

Klein, N. (2007). No logo: El poder de las marcas. Barcelona: Paidós.

Kotler, P. (2005). Preguntas más frecuentes sobre marketing. Barcelona: Granica. 
López-Pinto, B., Mas, M., \& Viscarri, J. (2008). Los pilares del marketing. Barcelona: Edicions UPC.

Martín, M.(2005). Arquitectura de marca. Madrid: ESIC Editorial.

Martínez, A. (2006, marzo). Creación de una marca ciudad. Documento de apoyo del V Curso de Dirección Pública Local. Madrid: Instituto Nacional de Administración Pública. Centro de Estudios Locales y Territoriales. Recuperado de http://bases.cortesaragon. es/bases/ndocumen.nsf/9ed3a8f9c37405f6cl2570a6002b47/d/24c0c4lOf75ea060cl2575d8002abadI/\$FILE/creacin\%20 marca\%20de\%20una\%20ciudad.pdf

Muñiz, N. (20I0, Noviembre). Marketing de ciudades y marcas de lugares institucionales -Place Branding-; un enfoque integral de transformación y promoción territorial. Conferencia dictada en IV Congreso Marketing de ciudades. Elche, España.

Ordozgoiti, R., \& Pérez, I. (2003). Imagen de marca. Madrid: ESIC Editorial.

Puig, T. (2009). Marca ciudad. Barcelona: Paidós.
Rey, J. (1997). Palabras para vender, palabras para soñar: introducción a la redacción publicitaria. España: Paidós Ibérica.

Rodríguez, I. (Coord.) (20II). Principios y estrategias de marketing. Barcelona: Editorial UOC.

Sabaté, J. (20I0, Septiembre). Discurso introductorio. Curso City Branding. Barcelona: CUIMPB-Centre Ernest Lluch.

Seisdedos, H. (20I0, noviembre). ¿Qué han aprendido nuestras ciudades? Análisis de las aplicaciones del marketing de ciudades en los últimos diez años. Conferencia dictada en IV Congreso Marketing de ciudades. Elche, España.

Silva, A. (2006). Imaginarios Urbanos. Colombia: Arango Editores.

Tresserras, J.(2004). La tematización cultural de las ciudades como estrategia de desarrollo a través del turismo. Turismo y Sociedad, 3, pp. $7 \mid-85$.

Zunzunegui, S. (1989). Pensar la imagen. Madrid: Cátedra. Universidad del País Vasco. 


\section{Tercera parte}

Innovación
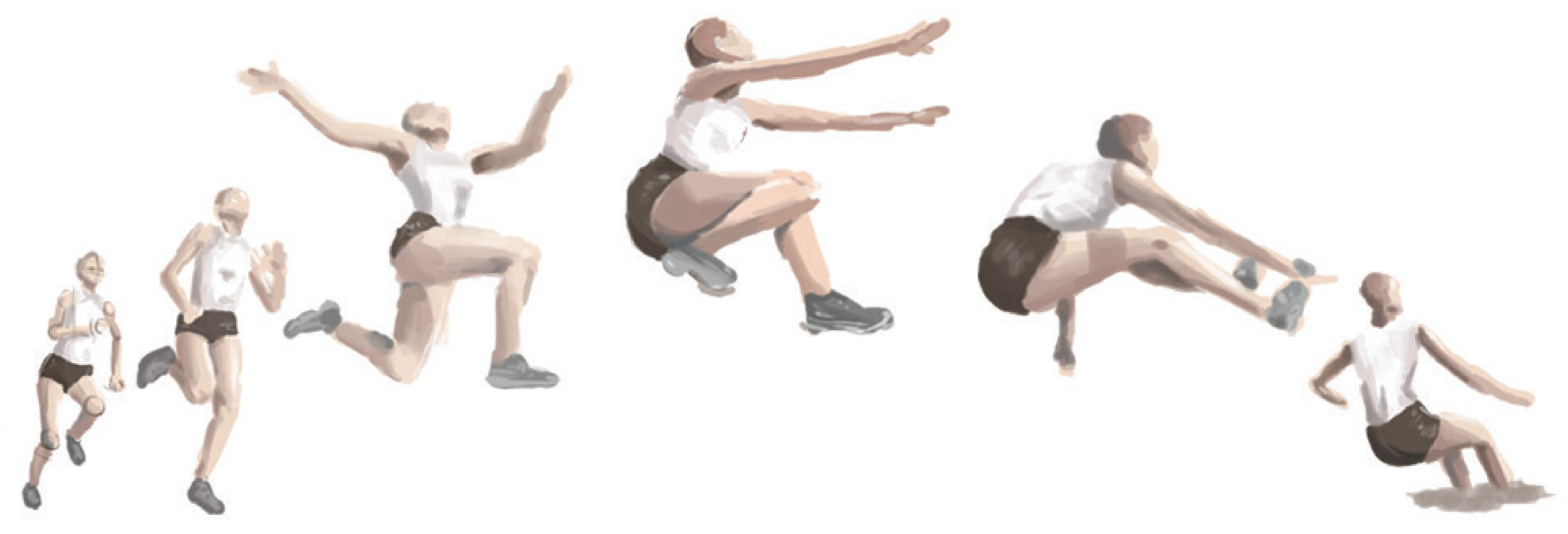


\section{Propuesta taxonómica}

\section{para las áreas subdisciplinares del diseño gráfico}

\author{
León Felipe Irigoyen Morales
}

\section{Introducción}

Las áreas de estudio de una disciplina deben de estar bien definidas para poder establecer los límites de la misma; si tratamos con un área demasiado amplia o relacionada con muchos factores de influencia, seguramente la eficiencia en su evaluación, su desarrollo y su estudio se verán comprometidos. Muchas veces se considera que las restricciones estructurales encierran y restringen, sin embargo no deberían de considerarse limitantes por naturaleza, sino organizativas.

A diferencia de las artes y las ciencias, en los oficios la especialización está fundamentalmente ligada a la labor, íntimamente ligada a la tecnología y su cuerpo de conocimiento no requiere absolutos, requiere amplitud y la pericia en solo un campo de acción no resulta práctico. Un buen diseñador deberá contar con un amplio repertorio de habilidades y conocimientos que tradicionalmente no se exige en otras disciplinas, la pregunta que debe hacerse es, ¿hasta donde tiene que ampliarse?

Digamos que no se espera que Van Eyck, Botero o Yayoi Kusama cambien sus formas o sus temas, así como un arqueólogo especializado en culturas de Asia Central realice variaciones en su campo de estudio porque ya está dejando de ser novedoso. Su pericia será altamente valorada y al no estar íntimamente ligado al desarrollo tecnológico, el factor de innovación puede no existir.

Basado en lo anterior, en el presente trabajo se analizarán aspectos que conforman un panorama cotidiano y contemporáneo que ayude a poner en contexto la situación del diseño gráfico, para después describir y proponer una clasificación para sus áreas 
subdisciplinares, únicamente como una forma de organización, evitando limitarse por estas fronteras autoimpuestas e invisibles.

\section{Problemas del diseño como disciplina}

No hace falta profundizar mucho en las ciencias biológicas, por citar un ejemplo, para demostrar que sus objetos y áreas de estudio están bien definidas. La microbiología estudia los organismos microscópicos y la biología marina los ecosistemas de los océanos. No hay mucho que discutir, al menos no desde el punto de la clasificación.

Los campos de estudio de muchas ciencias han sufrido una transformación constante desde hace cientos de años, pero el entendimiento general permite (aunque sea de forma superficial) explicar a qué se dedican. Por muy ajena que resulte un área podemos intuir (a veces desde la etimología) cuál es su área de estudio, qué características posee, incluso hasta qué habilidades son necesarias para llevar acabo las actividades propias de cada disciplina. En algunos casos inclusive pueden surgir comentarios acerca de su conformación como áreas económicamente importantes o muy interesantes.

En nuestro limitado entendimiento de una problemática específica, rápidamente se hace una lista mental de los profesionistas especializados que consultaremos o en los que será necesario apoyarse. Si hubo un terrible accidente donde se presentaron múltiples lesiones, inmediatamente se piensa en: paramédico, traumatólogo, anestesiólogo, cirujano, después ortopedista y una vez resuelta la crisis, cirujano plástico, psicólogo, abogado, etc.

A su vez, resultaría interesante hacer el mismo ejercicio de definición subdisciplinar con personas ajenas al diseño, para saber si de forma casi inmediata es posible resolver un problema pertinente al medio pensando en los profesionales a consultar.

Desafortunadamente no ocurre lo mismo con el diseño, mucho menos con el diseño gráfico. Quizás la problemática que tiene una fundación o una ONG requiere incluir la asesoría de un diseñador. La dificultad radicará en saber qué tipo de diseñador requiere.

Regularmente los grandes proyectos de imagen o gestión de la percepción pública requiere de un diseñador para el concepto visual y otro para el desarrollo de los gráficos, de un fotógrafo para que capte la escencia del concepto; un ilustrador freelance para hacer una propuesta específica; un copywriter para los textos; alguien que haga las funciones de un director de arte y ponga orden al asunto; y quizás hasta un mercadólogo para saber cuándo lanzar los resultados del proyecto. Una situación así rara vez funciona fuera de los grandes despachos y renombrados estudios.

Existen múltiples factores que intervienen en la situación recién planteada y seguramten varias partes terminarán insatisfechas, porque I) no se presenta una estandarización en los procesos; 2 ) los costos, las cotizaciones y el nivel de profesionalismo es sumamente variante; 3 ) los aspectos socioculturales y geopolíticos afectan horarios, fechas de entrega y respeto a los contratos; 4) los diseñadores no se apoyan en otros profesionistas ni tampoco suelen generan las relaciones que permitan recurrir a otros en caso necesario; y lo más triste de todo 5) terminan haciendo lo del publicista, sugiriendo estratégias de mercadotecnia, gestionando redes sociales, tomando fotografías, redactando pobremente contenidos web, desarrollando iconos, encargados de la dirección de arte, y un largo etcétera en ocasiones impuesto y/o premiado por los mismo clientes.

\section{Visón crítica a la formación del diseñador}

El diseño termina siendo una disciplina poco definida y dispar en su labor, que el entendimiento general de la disciplina ha sido oscuro y la opinión pública, confusa. Más preocupante resulta cuando los agentes que a ello se dedican y los que en esta disciplina se forman, no pueden definir claramente qué es, qué estudia y en qué aspectos el diseño se ve imitado o emulado por otra disciplina. 
Esto ocurre cuando el diseñador "domina" tantas cosas de distintas disciplinas pero jamás iguala la calidad de un verdadero profesional en dicha materia. Puede hacer campañas de publicidad pero no como un publicista; muchos saben pintar en óleo o hacer grabado pero nunca como un verdadero artista; se les enseña a hacer pautas para medios y escribir guiones pero nunca con el entendimiento de un comunicólogo; programar apps y sitios web, quizás visualmente más interesantes pero no tan precisas como las de un desarrollador o un ingeniero. Estos cientos de tareas sirven para contextualizar al estudiante de diseño pero que desafortunadamente, la cantidad de tiempo que se invierte en tantas cosas, invariablemente descuida áreas fundamentales de formación.

Aún existen aspectos poco delimitados dentro de la práctica profesional y la enseñanza del diseño gráfico que se solapan o trasponen; al no definir bien esto y mientras a los estudiantes no les quede claro qué se supone que deben hacer, qué es verdaderamente importante o qué implica cada una de estas labores, esto conllevará a un decrecimiento paulatino en la calidad de los resultados, derivando en frustraciones laborales o simplemente al nulo aprovechamiento de las destrezas individuales. Peor aún, semestres completos de "paja" que no les servirán de nada en el mundo laboral, competitivo y globalizado en el que se desenvolverán.

También preocupa la variedad exponencial de posibilidades profesionales que se desarrollan sin control, y lo poco reglamentado y pensado que están estas posibilidades. Muchas podrán sonar complejas y resulta difícil imaginar cómo establecer criterios para trabajarlas, lo cual se traduce en un problema de formación, que tendrán que saber adaptarse a un ritmo vertiginoso de desarrollo tecnológico, mientras que las escuelas tendrán que ofrecer, a corto plazo, propuestas curriculares valiosas y adecuadas.

De forma independiente, cada una de estas delimitaciones constituye un sinfín de posibilidades viables, con desarrollos par- ticulares que requieren conocimientos cada vez más específicos y materiales, discusiones y teorías propias. Lo mismo ocurre con las personas que transformarán estas nuevas industrias en un futuro cercano; requieren ser capaces de trabajar con un alto nivel de ambigüedad, con un entendimiento general de muchas áreas y acostumbradas a trabajar en equipos multidisciplinarios. Habrá que analizar, a su vez, cuántos diseñadores gráficos de la actualidad, y cuántos programas de formación cumplen con estos criterios.

Sin embargo, en algún momento habrá que organizarse y para hacer esto habrá primero que definir la perspectiva y los criterios para hacerlo.

\section{Clasificación por intereses}

El primer acercamiento para intentar poner orden, será con las personas que van a intervenir en el diseño. Quizás por el simple interés, los bachilleres seleccionan un área como el diseño, pero obviamente la primer sorpresa y el primer filtro es cuando no resulta ser lo que pensaban que se hacía, y surgen los enemigos de todo maestro: apatía, conflictos sin sentido, alumnos frustrados, deserción escolar y actitudes negativas. Tiene sentido preguntarle al que se inicia por qué estudiar diseño, qué busca lograr o cómo se percibe en el futuro pero realmente no se hace nada con las respuestas; no se aprovecha la interesante variedad de las respuestas que se reciben ni se da seguimiento a la evolución natural de aquellos que van madurando con la propia formación.

No se acostumbra hacer propedéuticos, ni exámenes de admisión específicos para la carrera; tampoco hay psicométricos, análisis objetivos de algún tipo y mucho menos pruebas de aptitud o de conocimientos generales. A veces ni siquiera se basan en los intereses para modificar los ejemplos o ejercicios; y rara vez nos acercamos a los estudiantes para conocer sus intereses.

Se iniciará retomando un gráfico que busca clasificar los intereses personales y que por lo mismo, ayudan a "filtrar" el tipo de 
personas que van a trabajar en distintas áreas. Quizás no está hecha para tomarse muy en serio por sus obvias limitaciones, pero en esta figura se plantean cuatro áreas principales, definidas a partir del interés personal que cada quien tiene. Por un lado tenemos el DESCUBRIR, por otro el PRESERVAR, en otro el APLICAR y por último el CREAR (Neumeier, 2006).

En teoría a partir de los intereses personales, las personas seleccionan cierta área por el tipo de actividad. Por ejemplo, si se trata de alguien interesado en DESCUBRIR, se asume que será curioso, apasionado y regido por intereses no monetarios. En teoría, las personas del PRESERVAR, deberían ser más disciplinados, un profundo respeto por los establecido y una ética laboral superior al promedio. Con respecto al APLICAR, quizás el interés está centrado en ayudar personas, o transmitir conocimiento; pero ¿qué pasa con las personas interesadas en CREAR?, ¿cómo deben ser sus personalidades?, ¿qué habilidades se necesitan?.

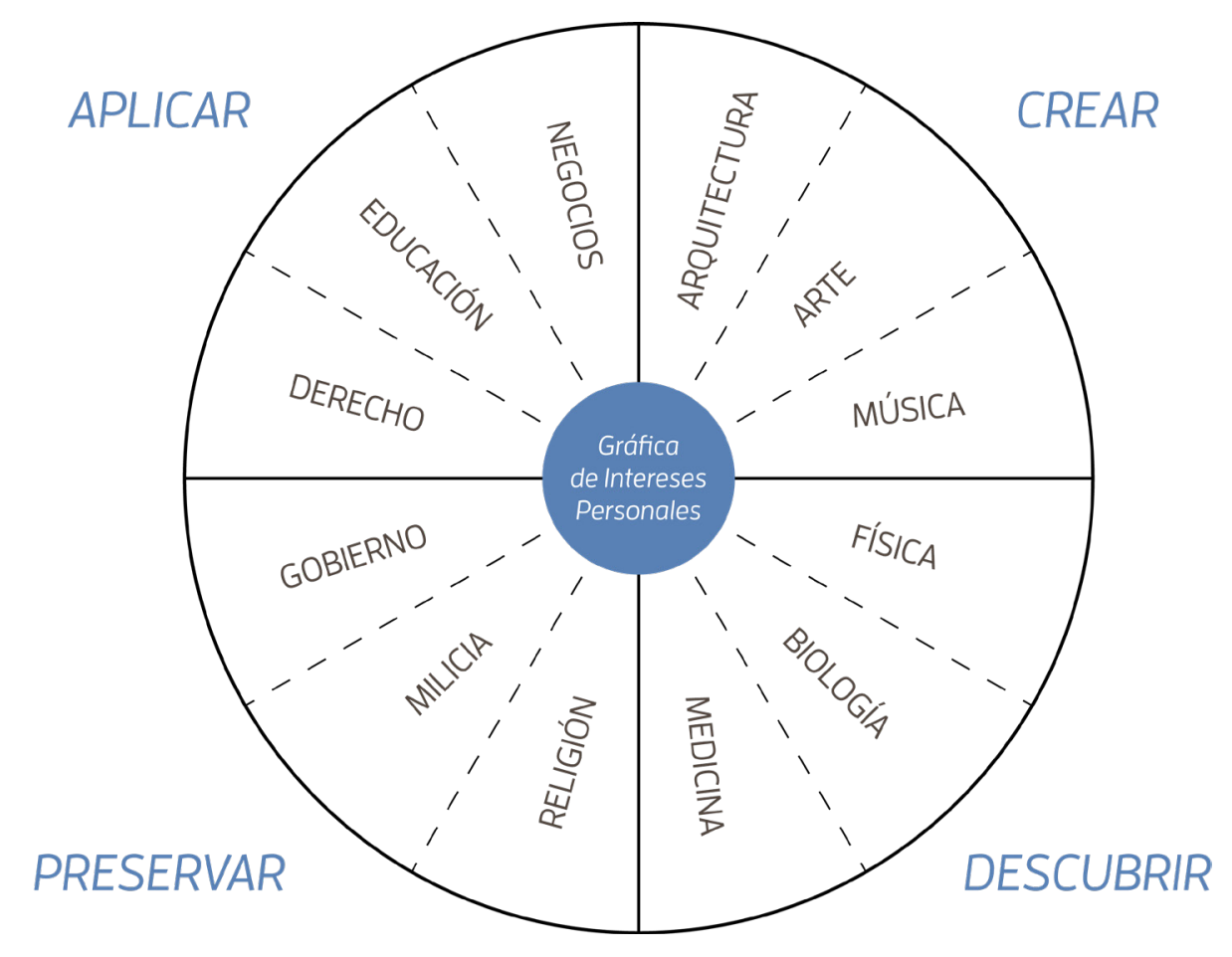

Figura I. I "Gráfico de los intereses personales" de Neumeier.
Una vez seleccionada un área en particular, por ejemplo, la biología, la música o el diseño, ¿se puede especializar o volver a separar los intereses?, ¿cómo volver a clasificar las obvias diferencias que existen entre las personas?. Desafortunadamente, este esquema no nos permite profundizar y terminaremos haciendo juicios generales (tales como: las personas interesadas en CREAR son extrovertidas, creativas, inconformes).

Básicamente, el primer intento clasificatorio, por medio de intereses, no funciona del todo, seguramente porque existe una gama de factores de influencia y que al tomar en cuenta otros parámetros, se pueden ampliar las posibilidades de clasificación.

\section{Clasificación Académica}

En el sentido estricto de la palabra, una clasificación clásica pudiera ayudar a establecer áreas de estudio tradicionalmente concebidas. Resulta bibliográficamente cómodo establecer clasificaciones a partir de áreas bien definidas, pero no resulta pertinente actualmente. De la misma forma que un libro de historia del arte publicado en el S. XIX resulta poco pertinente para entender vanguardias; o un libro de fotografía de 1980 habla de la posibilidad remota de almacenar fotografías de forma magnética; una clasificación del diseño como algo derivado del arte, resulta inapropiado para la época y es justo ahí donde se discrepa fundamentalmente.

Para muchos resultará incómoda la comparación pero en sentido estricto, el diseño, así como la orfebrería, el diseño industrial, el grabado, los interiores o la moda, se puede considerar un "arte aplicado". Según la clasificación tradicional reciben una clasificación menor, padeciendo constantemente una especie de desdén, simplemente porque el componente funcional ha resultado más valioso que el factor contemplativo y objetual.

En este sentido, Bürdek (2002) ya comentaba cómo se formaba lentamente un estudio del diseño que daba pauta para que comenzaran las confrontaciones sobre cómo se ha de organizar 
"interdisciplinar, pluridisciplinar o transdisciplinar"-mente. Más importante resultaba el comentario de la "poca confianza depositada en sus propias contribuciones que necesitan apoyarse en otras disciplinas" (Bürdek, 2002). En este mismo libro, retomaba varios aforismos de Bernd Vossmerbáumer que llevan a lo mismo:

I. El arte tiende ante todo a lo inmaterial, el diseño lo admite como consecuencia.

2. El arte no es en modo alguno útil, y es sólo receptible cognoscitivamente...

3. El diseño necesita objetivación, el arte es espiritualización.

4. El diseño es siempre consecuencia, el arte siempre origen, y a manera de broma,

5. Los diseñadores aliñarían las fresas con limón. Los artistas idearían una fruta nueva.

Obviamente el diseño no está exento de casos y proyectos que bajo una clasificación académica tienen más que ver con los deseos del arte que con la función del diseño. Es más, también se presenta un funcionalismo excesivo que al intentar "limpiar" al producto o al objeto de todo significado provoca un estatus de culto hacia los objetos de diseño, desde sillas, cafeteras, equipos de sonido y automóviles cuyas características de construcción y reducción absoluta de elementos, irónicamente se convierten en objetos de deseo, tan poco democráticos que convierten el diseño en un activo más que un proceso, en símbolos de estatus y no en herramientas para facilitar nuestras vidas. Estos excesos contradicen la verdadera función de solución de problemas del diseño y "regresan" al arte objetual de admiración y decorado, ideales para contemplarse pero imprácticos para transportarse o alimentarse.

Al atreverse a asegurar que todo aquello que es funcional es diseño y que todo lo contemplativo es arte, se termina regresando al mismo lugar. Si el afán clasificatorio estuviera sujeto al tipo de función comunicativa (en un cartel o en el diseño tipográfico,

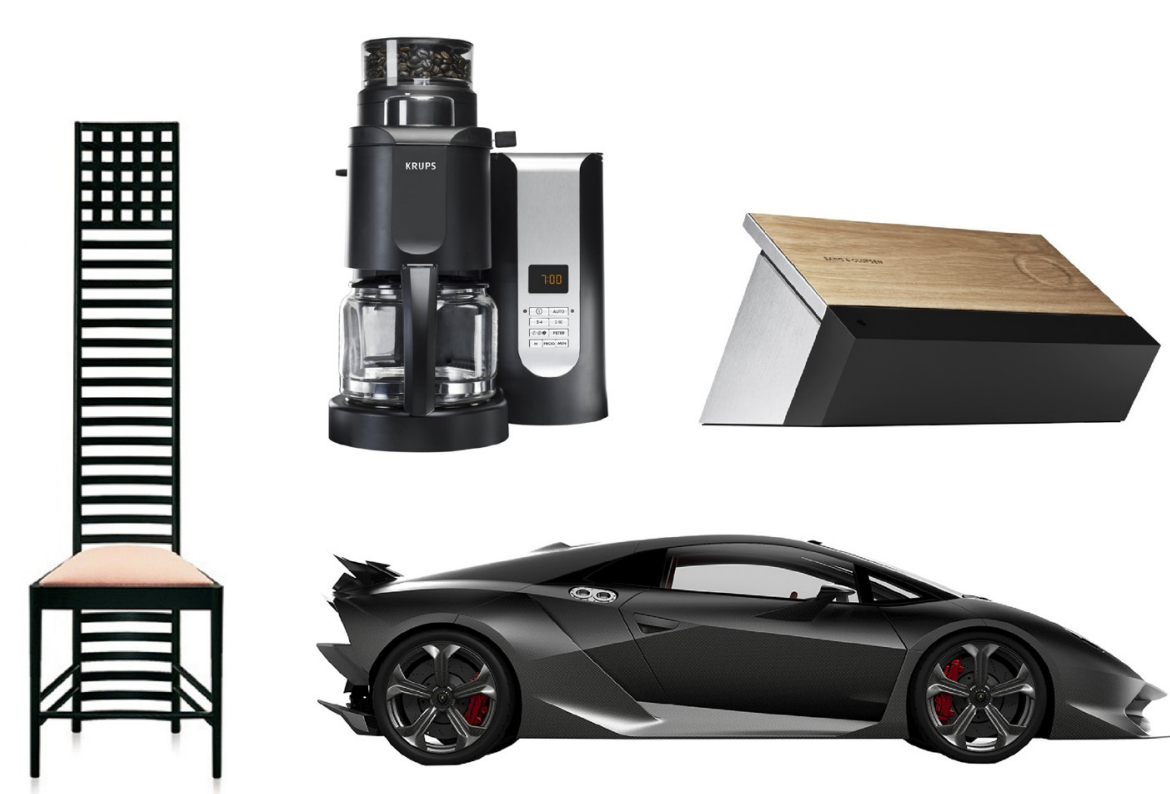

Figura 2. Cuando el aspecto estético del objeto de diseño se valora en exceso, se aleja de su función primaria y se acerca al estatus "de culto" dando pauta a un ejercicio inútil e infructuoso.

por ejemplo), de contención y transporte (en el empaque), de interacción (en un tablero de controles o en un cajero acutomático) o de representación (una bandera, los iconos de una aplicación), se puede empezar a aclarar y a reducir un poco el panorama. Sin embargo, irónicamente, estos resultados también poseen un alto contenido simbólico y objetual propios del arte o la semiótica y que siguen sin ofrecer precisiones para clasificar la disciplina.

\section{Los órdenes del diseño}

Por otro lado, quizás la variedad y la creciente amplitud del diseño tiene que ver justamente con los campos y áreas donde el diseñador se desempeña. A pesar de que las herramientas, los procesos y los materiales o términos pueden variar increíblemente, un diseñador industrial, gráfico, digital, de experiencias de usuario, de moda, de interacciones, textil, de sistemas, de iluminación y so- 
nido, de joyas y accesorios, será propiamente considerado como diseñador. Incluso el diseño aplicado a servicios, sistemas educativos o estilos de vida son áreas de intenso interés últimamente.

Para esto, Buchanan (1992) propone organizar estos campos en 4 órdenes principales que se articulan a través de las dimensiones propias de los resultados. Básicamente en el primer orden se clasificaba todo aquello que tenía que ver con signos y símbolos, es decir, lo propio de la representación bidimensional del diseño gráfico. Evidentemente esto es muy amplio pero lo que busca es contextualizar y ampliar el panorama del diseño como disciplina.

En el segundo orden, tiene que ver más con el diseño industrial, incluyendo todos los objetos de los que la gente hace uso. Sin embargo, aunque este segundo orden se refiere a los objetos tangibles, artefactos y resultados de una producción en masa, no incluye las representaciones tridimensionales de los mismos, esto en parte por el aún pueril desarrollo tecnológico en materia de $C A D$, visualizaciones y software de modelado y animación.

Retomando, el tercer orden precisamente tiene que ver con el tiempo (la cuarta dimensión), donde existen servicios o actividades relacionados precisamente con la interacción y productos basados en el movimiento y el tiempo; dícese de todo aquello relacionado con la animación, motion-graphics, títulos, web banners y demás presentaciones que, independiente a la técnica, la intención o a la tecnología involucrada para dar (aunque sea la ilusión de) movimiento, se presenta de esta forma.

Y por último, el cuarto y más complejo de los órdenes propuestos: los sistemas y ambientes. La planeación urbana, el diseño organizacional, los sistemas arquitectónicos, proyectos multidisciplinarios y la presencia de múltiples stakeholders son medios altamente complejos que incluyen o se relacionan con intereses propios de la sociedad, el gobierno, distintas comunidades, políticas públicas, leyes regionales, aspectos medioambientales y se majean en múltiples dimensiones.
Como ejercicio organizativo resulta interesante y tiene sentido, el único desacierto es que Buchanan desarrolló esta propuesta mucho antes de la Revolución Digital dejando de lado muchos de los componentes e interacciones que hoy delimitan el diseño. En resumen, es importante considerar estos lugares conceptuales para interpretar e intervenir en estas áreas, entendiendo su potencial y como una forma de organizar un campo de acción cambiante y creciente. Generará mucha controversia al apoyar el estudio en los "campos del ayer" (gráfico e industrial) en vez de apoyarlo en "áreas emergentes" (diseño de servicios y sistemas).

Gajendar (2008) comenta justo a este respecto que la imaginería, la tipografía, el color, los formatos, retículas y principios de diseño seguirán siendo igual de importantes ya sea que se apliquen en un aspecto aún por definirse, una tecnología por desarrollarse o un objeto aún por imaginar, ya que estos elementos darán forma a los mensajes y a la comunicación.

Sin embargo, conflictos de alto nivel en las relaciones sociales, puntos de contacto de la identidad de una marca, la retroalimentación generada en la atención al cliente, la eficiencia comunicativa en interfaces digitales y los flujos de información dentro de un sistema, deben ser considerados piezas de diseño igual de importantes como cualquier otra tecnología de interacción.

Gajendar concluye haciendo referencia al potencial fascinante y provocativo de los conceptos y métodos inherentes a los enfoques innovadores, que parafraseando, son capaces de influir o incluso formar relaciones, comportamientos y valores de las personas dentro de grandes esferas de actividades concernientes a sus problemas y contextos.

\section{Estableciendo el contexto científico}

Desde las etapas más primitivas de la vida humana, la necesidad de nombrar cosas ya existía. Poder identificar aquellas cosas que son comestibles o aquellos animales que pueden hacernos daño, 
dándoles un nombre es un trabajo que se fue haciendo con el mayor de los cuidados (la tradición judeocristiana dicta que fue Adán el encargado de dicha tarea). Es decir, necesitamos articular sonidos o gestos y asociarlos a cada uno de los sustantivos posibles mucho antes de la creación de un lenguaje con una gramática compleja y crear variaciones o combinaciones distintas para poder identificar claramente cada uno de los deseos.

Teofrasto, discípulo de Aristóteles, fue uno de los primeros en concentrarse alrededor del 300 a.c. en la nomenclatura de plantas a través de varias obras que se mantuvieron como norma de importancia durante muchos siglos.

Desde el Renacimiento varios intentos de clasificación biológica se han dado por medio de la variación de los criterios y rompiendo los paradigmas establecidos por la tradición. Por ejemplo, el médico italiano, Andrea Cesalpino fue el primero en romper la tradición de clasificación alfabética por propiedades medicinales sustituyendo la clasificación de las plantas según sus frutos y semillas. Luego, otros botánicos y naturalistas, como Augustus Rivinus o John Ray clasificaron flora y fauna por medio de la observación directa de sus estructuras, prescindiendo del saber antiguo.

Tiempo después, el botanista sueco Carlos Linneo estableció los fundamentos para la taxonomía moderna, estructurando una jerarquía de grupos a distintos niveles para todos lo seres vivos, para hacer frente a la compleja diversidad biológica existente en el planeta. Implementó un sistema de nomenclatura binominal que resultó ser una solución elegante para la literatura desorganizada en las ciencias biológicas. Surge así el sistema de clasificación científica que lleva su nombre y que aún se utiliza prácticamente sin cambios desde el sigo XVIII.

Elaborando, este sistema inicia en el Reino (plantas, animales, hongos, protistas y bacterias), para seguir con el Filo (dependiendo de su naturaleza corporal y otros aspectos morfológicos), la Clase, el Orden (con rasgos esqueléticos y dentarios distintivos), la Familia, el Género (describiendo el tipo básico de organismo) y la Especie (el único nivel del sistema que puede ser definido objetivamente, permite que los organismos de la misma especie puedan cruzarse sin generar híbridos).

En la Figura 3 se observa un ejemplo de clasificación científica y cómo se ordenan sus características según lo establecido por Linneo. El nivel de especificación posible es admirable.

\begin{tabular}{|c|c|}
\hline REINO & Animalia \\
\hline FILO & Chordata \\
\hline CLASE & Mammalia \\
\hline ORDEN & Carnivora \\
\hline FAMILIA & Felidae \\
\hline GÉNERO & Panthera \\
\hline ESPECIE & Panthera onca hernandesii \\
\hline
\end{tabular}

Figura 3. Ejemplo de clasificación para el jaguar centroamericano.

Para contextualizar, la labor de Linneo aunque originalmente aplicada a la biología, se dio precisamente porque existía un problema clasificatorio muy grave. Es por ello que resulta interesante aprovechar esta estructura para organizar el entendimiento de la tecnología y las ciencias (Ver Fig. 4 y 5).

\begin{tabular}{|c|c|}
\hline CLASE & tecnología \\
\hline ORDEN & dura \\
\hline FAMILIA & ingeniería \\
\hline GÉNERO & mecánica \\
\hline ESPECIE & aeronáutica \\
\hline
\end{tabular}

Figura 4. La ingeniería aeronáutica puesta en contexto. 


\begin{tabular}{|c|c|c|c|}
\hline CLASE & \multicolumn{3}{|c|}{ ciencias } \\
\hline ORDEN & naturales & sociales & formales \\
\hline FAMILIA & físicas & comportamiento & matemáticas \\
\hline GÉNERO & química & psicología & cálculo \\
\hline ESPECIE & analítica & clínica & diferencial \\
\hline
\end{tabular}

Figura 5. Los distintos tipos de ciencias, derivados de su "ORDEN".

Apoyarse en esquemas visuales también ayuda a relacionar áreas y resulta cómodo utilizar la estructura propia de las ciencias para extender la labor organizativa hacia otras disciplinas.

Por ejemplo, cuando se habla de las clasificaciones del arte, también resulta sumamente complejo el ubicar en contexto y poder definir objetivamente cada variante, escuela, estilo, técnica, época, referencia, respuesta de cada uno de las posibles interpretaciones y ejecuciones en todos los tipos de arte. Lo cual da pauta a otra serie de controversias y tecnicismos que aquellos interesados en el tema tendrán que discutir (Ver Fig. 6).

\begin{tabular}{|c|c|c|}
\hline FILO & \multicolumn{2}{|c|}{ artes } \\
\hline CLASE & \multicolumn{2}{|c|}{ bellas artes } \\
\hline ORDEN & literarias & artes plásticas \\
\hline FAMILIA & prosa & pintura \\
\hline GÉNERO & narrativa & contemporánea \\
\hline ESPECIE & novela autobiográfica & $\begin{array}{c}\text { expresionismo figurativo } \\
\text { norteamericano }\end{array}$ \\
\hline
\end{tabular}

Figura 6. Las bellas artes han sido muy estudiadas desde hace mucho tiempo desde un sinfín de perspectivas. Sin embargo, existen pocos esquemas organizativo que expliquen y contextualicen.

Luego entonces, si el ejemplo anterior permite establecer el mismo criterio también para arte, el paso hacia las Ilamadas "artes menores" no debe ser tan drástico. Aquí habrá que establecer bien los criterios disciplinares según lo que cada área busca delimitar y estudiar propiamente.

A continuación se establece una clasificación similar a la realizada para las bellas artes pero específica para las artes aplicadas (interiorismo, orfebrería, moda, mobiliario...). Esta puede ampliarse y extenderse en sentido horizontal de múltiples formas.

\begin{tabular}{|c|c|c|}
\hline FILO & \multicolumn{2}{|c|}{ artes } \\
\hline CLASE & \multicolumn{2}{|c|}{ artes aplicadas } \\
\hline ORDEN & \multicolumn{2}{|c|}{ comunicación visual } \\
\hline FAMILIA & diseño & fotografía \\
\hline GÉNERO & modas & paisaje \\
\hline ESPECIE & Prêt-à-porter & arquitectónica \\
\hline
\end{tabular}

Figura 7. Las artes aplicadas son igual de complejas y requieren de una contextualización para poder clasificarlas objetivamente.

\section{Propuesta cladística}

Ahora bien, la clasificación de Linneo sirvió durante muchos años para ubicar las distintas especies naturales conocidas. Sin embargo, en la ciencia así como en el diseño, existe un sinfín de innovaciones y tecnologías que afectan y continuarán expandiendo los horizontes establecidos.

Esto fue lo que sucedió justamente con un acercamiento a la clasificación biológica donde los organismos son agrupados dependiendo de las características derivadas de un antepasado común. Es decir, a partir del descubrimiento de patrones evolutivos, se definen las relaciones basadas en similitudes derivadas. 
La cladística es una rama de la biología que aprovecha los grandes conocimientos relativamente modernos de la genética, de agentes artificiales, las interacciones complejas entre especies, la afectación humana y lo relacionado con la conservación. El desconocimiento del ADN y el ARN para los científicos de la antigüedad, los llevó a tomar decisiones con el conocimiento de la época. Actualmente la clasificación cladística (propuesta por el alemán Willi Henning en 1950) hace uso de diagramas de árbol (técnicamente conocidos como dendogramas) para organizar los datos en subcategorías que se continúan dividiendo hasta llegar al nivel de detalle deseado.

Sin profundizar mucho en este tema, la presente propuesta busca establecer grandes áreas en las cuales puedan ser acomodadas las distintas modalidades del trabajo de un diseñador gráfico, y que las relaciones que se establezcan entre ellas se fundamenten en la lógica y el sentido común.

Independiente al desarrollo tecnológico o al enfoque económico, pedagógico o social que seguramente afectará los contenidos más específicos, existen muchas cualidades y grandes áreas de conocimiento en común, que requerirá a su vez de habilidades y destrezas particulares.

Como propuesta inicial se establecen 5 grandes secciones a partir de sus campos de estudio (Teórico, Representacional, Informativo, Simbólico y Editorial). Aunque seguramente será posible extenderlo hacia al menos 3 grandes áreas adicionales (Dinámico, Proyectual e Interactivo) las cuales serán abordadas brevemente, posterior al desarrollo de cada una de las secciones propuestas (Ver Figura 8).

A continuación se desarrollan por separado y sin ningún orden particular las grandes áreas subdisciplinares que actulamente competen al estudio y enseñanza del diseño, y particularmente al diseño gráfico. Sus contenidos están relacionados únicamente por el aspecto temático.

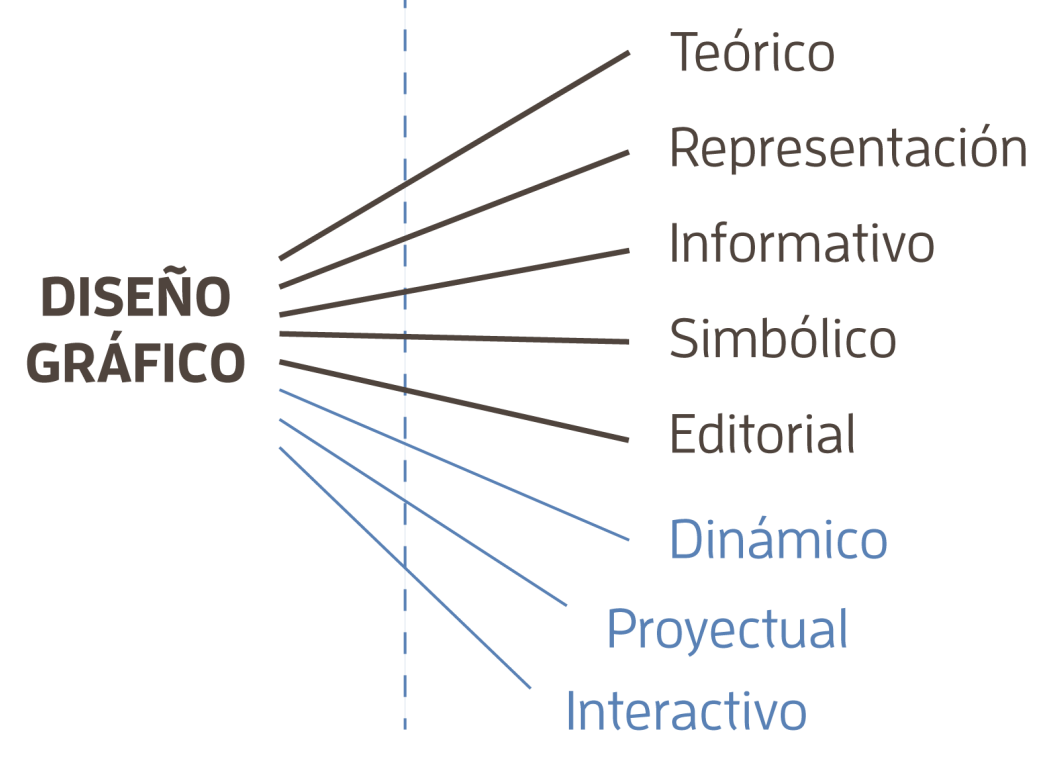

DISCIPLINA

CAMPO DE ACCIÓN

Figura 8. Diagrama de árbol cladístico que incorpora las áreas de estudio del diseño gráfico. La última parte (color azul) corresponde a campos de estudio posibles, son una extensión del esquema.

\section{Teórico}

Existen grandes temáticas y mucho qué discutir con respecto a los aspectos socioculturales, geopolíticos, educativos, económicos, así como los psicológicos, biológicos y físicos que afectan la percepción humana y cómo todo esto impacta la profesión del diseño. La investigación en diseño, como una gran área temática tiene que ser propia de los profesionales en el área, muchos sociólogos, psicólogos y profesionistas aún más ajenos al diseño, constantemente hablan de temas y abordan problemáticas que se tienen que trabajar "in house". Este desconocimiento natural del mundo del diseño provoca que mucha de la literatura del diseño abarque temáticas "elevadas" o ajenas a la realidad contemporánea del diseño; esta es una de las áreas subdisciplinares que más pauta da para su investigación y discusión. 
Lo mismo sucede con los aspectos metodológicos e históricos. Por un lado, la continua discusión de la existencia de metodologías únicas de diseño, o de la proliferación de métodos para la creación de soluciones y el estímulo de ideas, deben ser entendidas únicamente como herramientas prácticas, las cuales requieren atención y discusión continua. Aunque se trate de métodos derivados de la publicidad, los negocios o la mercadotecnia, son utilizados indistintamente en diseño, en su formación educativa y en la profesión sin ningún rastro de inconformidad. Con más ímpetu en las últimas décadas muchos investigadores han variado los enfoques y se han creado o retomado métodos con mayor conciencia social, medioambiental, centrados en el humano y que aseguren su continuidad.

De igual forma, los estudios exhaustivos que se han hecho con respecto a la historia del arte no se comparan a la tibia y temerosa iniciativa mostrada por diseñadores en esta importante área. Algunas iniciativas mostradas por publicaciones universitarias norteamericanas o algunas instituciones europeas han vuelto a poner en la mesa de discusión temas específicos para la investigación y enseñanza de la historia del diseño. Desafortunadamente, los esfuerzos adicionales se han centrado más en profundizar aspectos regionales y populares que poco han impactado la enseñanza universitaria, poco han sensibilizado hacia las temáticas ajenas a nuestra propia realidad y se han mantenido débiles al momento de fomentar el interés general en la materia.

En estas primeras "especies", la teoría, la metodología y la historia, hay mucho camino por recorrer retomando el diseño como punto de origen, limitando el abordaje de temas de diseño desde la perspectiva reservada y miope de otras disciplinas.

\section{Representación}

A pesar de tratarse de una habilidad que se desarrolla en muchas ciencias, ingenierías y es un aspecto fundamental en arte, la ca- pacidad de representar complementada por todo aquello que esté relacionado con el dibujo es una parte inherente al diseño. Sin embargo, la intención, la técnica o tecnología empleada varía enormemente la forma en como debe abordarse, derivando en gama virtualmente ilimitada de resultados y aplicaciones de las mismas.

La propuesta separa tres grandes áreas del dibujo en el diseño, la ilustración (con gran tradición histórica y una riqueza cultural enorme), el modelado (desarrollado muchas veces por artistas digitales o por ingenieros) y la escultura (aunque similar en su intención, su creación maneja principios muy distintos). El modelado tridimensional por computadora es cada vez más común en muchas industrias porque permite simular y visualizar productos, ambientes y situaciones que antes era sumamente tardado y por ende costoso. Paulatinamente ha afectado nuestro entorno a través de empaques, personajes, anuncios publicitarios, juguetes, demostraciones (...) y su estudio se incorpora cada vez más fácil a los programas de diseño gráfico.

La escultura tridimensional también es un área en apogeo que, aunque ha tenido mayor impacto en videojuegos y diseño industrial, también resulta natural incorporar al diseñador gráfico como el profesional que se encargue de su ejecución, áreas que tradicionalmente incorporaban artistas plásticos. Quizás el modelado y la escultura digital se puedan incorporar en una sola especialidad debido a sus características comunes: el empleo de tecnología computacional para su existencia, el empleo de software altamente especializado para su creación; su naturaleza virtual y de simulación tridimensional (que gracias a la depreciación de la impresión tridimensional se verá nutrida a corto plazo). En esta propuesta se mantienen separadas simplemente por que manejan principios de creación distintos.

Retomando el aspecto de la ilustración y manteniendo al margen el objetivo de la misma, se denotan 3 tipos de ilustración fundamentales: la creada de forma tradicional, denominada para 
motivos prácticos como orgánica, la ilustración vectorial y las imágenes ráster (compuestas de pixeles). Sin importar la naturaleza decorativa, comparativa, demostrativa o simplemente ilustrativa del trabajo gráfico, solamente pueden ser creadas de estas formas. La categoría "orgánica" se denota para todo aquel esfuerzo que incorpore medios físicos y técnicas tradicionales para su creación (tintas, pinturas, recortes, aerosoles y cualquier posible combinación de estos). Pueden o no incorporar el uso de nuevas tecnologías pero los que invariablemente requerirán tecnología computacional, son las vectoriales y la pintura digital.

La tecnología de curvas vectoriales, se ha convertido en un estándar obligado en el diseño gráfico y su creación no requiere de grandes recursos ya que no necesita grandes cantidades de procesamiento ni almacenaje. Por último, el uso de periféricos de dibujo con estiletes, o más recientemente, el uso de los dedos para ilustrar en tabletas sensibles al tacto, ha impactado la facilidad y rapidez con la que se obtienen resultados muy variados. La llamada "pintura digital" es esencialmente distinta a la creación vectorial por lo que se sugiere mantenerlas separadas (Ver Fig. 9).

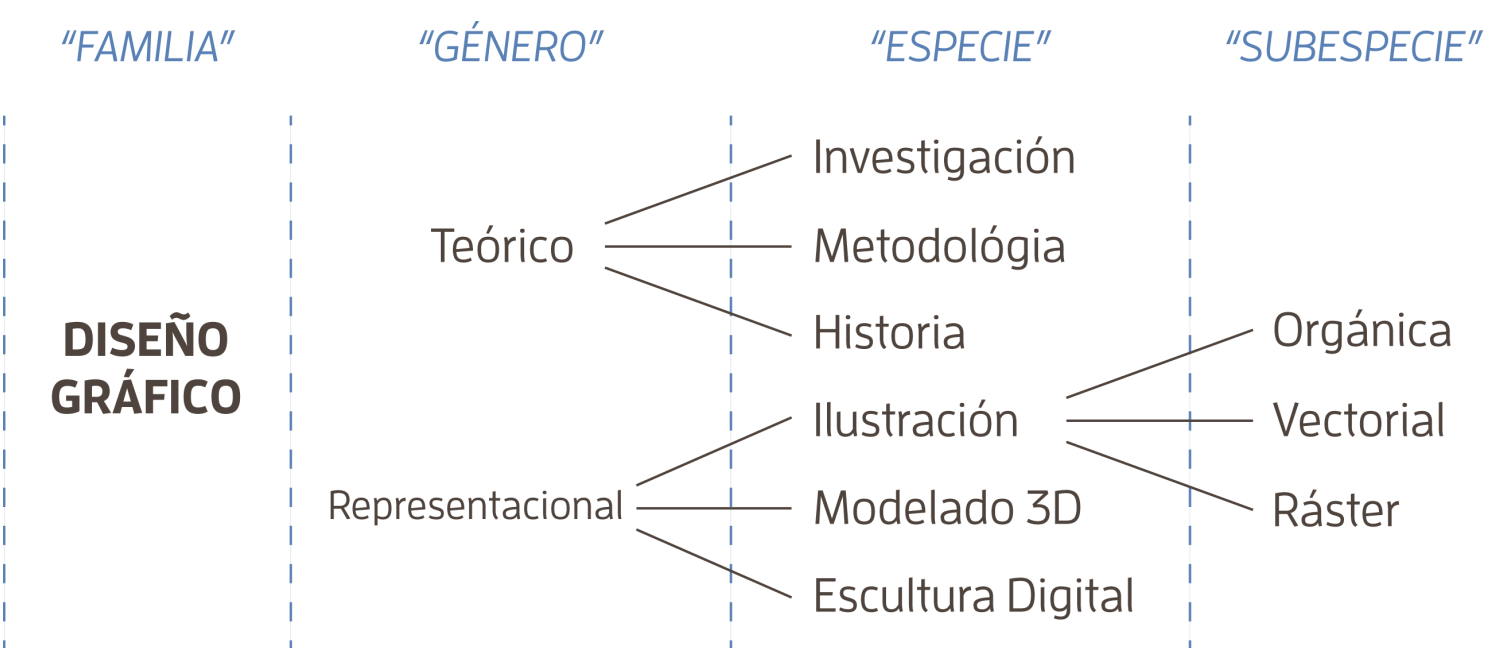

Figura 9. Detalle de los campos "Teórico"y "Representacional" con su correspondencia taxonómica.

\section{Informativo}

La necesidad humana de manejar información siempre ha existido, pero aproximadamente desde la Revolución Industrial y la creación de las grandes bolsas de valores mundiales, la cantidad de información que se necesita procesar, representar y compartir no ha hecho más que crecer. Esto aunado a la revolución digital que ha hecho que medios como el internet y la proliferación de medios audiovisuales y gráficos estén saturados de datos que difícilmente son depurados por el usuario. Es por ello que las necesidades propias de cada tipo de información se ha tenido que especializar cada vez más, y de la misma forma que en los casos anteriores, se divide en 3 grandes áreas principales: la señalética, el diseño web y las infografías.

Tradicionalmente el desarrollo de sistemas señaléticos siempre se ha incorporado como parte de las aplicaciones de una marca en los espacios arquitectónicos relacionados con la misma, pero las necesidades de orientación e identificación superan por mucho la mínima y opcional sección de los manuales de identidad que hablan al respecto. Sin importar la naturaleza informativa, restrictiva o preventiva que dicha señal tenga, el diseño y creación de estos sistemas deben ser tomados más en serio para que dicha subdisciplina florezca de forma independiente.

El diseño de sitios web es otra área altamente competida en la que intervienen ingenieros, desarrolladores, comunicadores, etc. y que puede ser apreciada y trabajada desde múltiples perspectivas. Sin incluir aquí el desarrollo de software y apps, el diseño web propiamente dicho es un área que aunque incorpora muchos elementos tipográficos, de diseño editorial y principios de comunicación, es desde hace ya varias décadas un área subdisciplinar de gran importancia económica, que incorpora cambios súbitos frecuentemente y posee una elevada complejidad tecnológica.

Por otra parte, la visualización de datos y el diseño de interfaces son áreas pobremente exploradas que incorporan por sí solas, 
una cantidad enorme de teoría y lenguajes propios cuyas necesidades y preocupaciones tienen que ser tratadas con mayor atención en los programas formativos. La creación de visualizaciones conceptuales, líneas de tiempo, gráficas, tablas y mapas son solo algunas de las áreas tratadas por la infografía, ya que las interfaces de usuario con las que funcionan los tableros de comandos, los videojuegos, las pantallas de los cajeros automáticos, las herramientas de vuelo y todo lo que tenga que ver con realidad aumentada es tratada de cierta forma con interfaces diseñadas.

Recapitulando, la necesidad de diseñar mensajes más eficientes, dar información más precisa y hacer que los usuarios interactúen más fácilmente con un objetos o máquinas, debe ser estudiada a fondo en un área propia del diseño gráfico.

\section{Simbólico}

Todo aquello de naturaleza simbólica puede por su propia naturaleza, ser interpretado de muchas formas. Lo que interesa en el diseño gráfico es justamente la creación de conceptos creativos para representar y comunicar lo deseado, aunque se trate de una marca, un cartel o un objeto. Estas 3 "especies" y sus posibles "subespecies" dependen de múltiples factores perceptuales y culturales que han definido los lineamientos para optimizar su uso.

En el primer caso y desde los orígenes del "dibujo publicitario" de la revolución industrial inglesa (que dio pauta para las primeras marcas registradas) hasta el branding (la propia creación y gestión de marcas) moderno, el diseño de símbolos y logotipos siempre ha sido de naturaleza gráfica y un componente vital para el éxito de cualquier institución. Últimamente se ha extendido a lugares, personas, eventos, causas y comunidades que han visto en la creación de una imaginería y unos símbolos propios, exaltada la representación de sus valores e ideales.

El cartel tiene un lenguaje propio y requiere ser tratado de forma única, y aunque se trata de una subdisciplina del diseño alejada de la denotación de "industria", carecer de investigación serie y poseer pocos, casi nulos tratamientos teóricos, está más vivo que nunca. Sus orígenes propagandísticos se ven reflejados en ciertos países de influencia postsoviética, donde aparece cierta tradición y prestigio, que se ve igualado por otros países específicos. Sin embargo, pocos programas actuales de diseño retoman esta tradición como pieza fundamental y lo incorporan como un componente obligado en la educación de la representación.

Finalmente, el packaging (para no utilizar el controvertido trinomio compuesto por empaques, envases y embalajes) define desde su forma primaria el nivel interpretativo de la función. Es decir, no es necesario el aspecto cromático, lingüístico, nominativo ni marcario para identificar se función. Desde la definición de formas que los materiales seleccionados permitan, se puede saber si se trata de un envase de aceite para motor, un jugo de naranja, una bebida alcohólica o una crema facial. El empaque es en su nivel más básico, simbólico, y reune mucho del trabajo de diseño en una especie de ágora de conocimientos que se superponen en un solo objeto.

Es posible incluir otras áreas que también son de naturaleza simbólica (tales como la heráldica, la filatelia o la numismática), que mantienen el aspecto gráfico, funcional y visual, pero no queda bien definido si se trata de áreas de interés al diseño gráfico o son simplemente aplicaciones individuales y con un alto riesgo de extinción en las próximas décadas que quizás solo la vexilología pueda evitar.

\section{Editorial}

Desde la invención de la imprenta tipográfica en Europa a principios de 1400, la creación de documentos escritos que fueran rápidamente reproducibles y fácilmente transportables afectó con una magnitud inimaginable el Renacimiento, la Reforma, la llustración y la Revolución Científica (Meggs y Purvis, 2012). 
Por un lado está la tipografía (visto como el diseño de fuentes y familias tipográficas y no como sistema de impresión), la producción de materiales impresos (así como el conocimiento derivado de todas las etapas y fases para su creación) y finalmente el área digital (área iniciada con la depreciación del desktop publishing, actualmente tiene sus propios medios, lenguajes y tecnologías), se diferencia a su vez entre libros electrónicos y publicaciones digitales debido a la naturaleza adaptativa (líquida) y flexible del texto en el primer caso, y por la incorporación de elementos multimedia en la maqueta fija del segundo caso.

Aunque esta última subdisciplina encuentra mucha renuencia en su desarrollo (gracias a la industria editorial mundial y lo complejo del derecho de autor), el diseño gráfico no ha hecho más que verse nutrido y beneficiado por la incorporación y proliferación de soluciones económicas y democráticas (Ver Fig. I0).

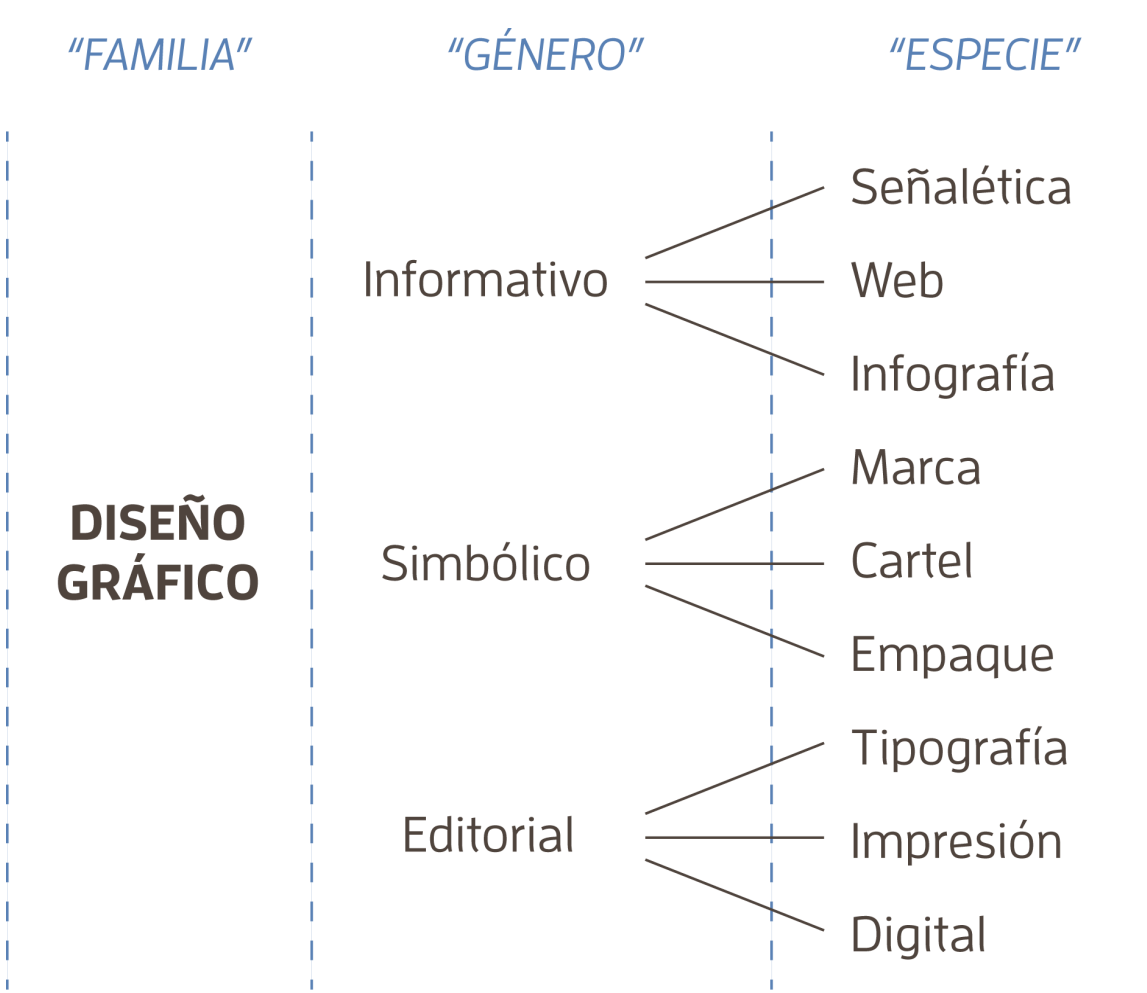

Figura 10. Detalle del resto de los posibles campos de acción del diseño gráfico.

\section{Áreas de posible expansión}

Esta parte requiere aún de mucho análisis y discusión puntual. El diseño como disciplina obviamente seguirá creciendo de forma directamente proporcional al desarrollo tecnológico existente en cualquier época y cultura. Ciertas extensiones que para algunos individuos 0 instituciones innovadoras ya resultan pertinentes, muchas veces están definidos por el éxito comercial que denota el ubicar ciertos nicho de mercado, sin poner en tela de duda su temporalidad. Pero es natural pensar que existen otras áreas de acción menos tradicionales que por la misma complejización de la labor del diseño se desarrollarán a corto y mediano plazo.

\section{Dinámico}

Los aspectos dinámicos, es decir, todo aquello que presenta movimiento, requiere toda una serie de habilidades y técnicas (derivadas seguramente de la cinematografía), es poseedor de su propio léxico y requiere de una sensibilidad y forma de trabajo particular. Aquí se separan otras 2 subdisciplinas, la animación y el diseño audiovisual (motion graphics). Ambas de existenciasrelativamente corta pero debido a la importancia que representan a la profesión, ameritan ser tratados como parte de la misma, si no, continuarán como alternativas cinematográficas tradicionales (en el caso de la caricatura) o como alternativas tecnológicamente posibles (en el caso de la animación por computadora, vinculada invariablemente al modelado 3D y a la escultura digital).

De forma similar, Meggs y Purvis (2012) hacen referencia a la incorporación de las gráficas en movimiento con la expansión tecnológica de las televisoras norteamericanas. Señalan que entre 1945 y 195I el trabajo de Georg Olden y William Golden (diseñador del emblemático ojo de la CBS) crearon los equipos de trabajo necesarios para crear imágenes para mostrarse "al aire", definiendo un rol definitivo en el desarrollo de las gráficas para televisión y por ende el inicio de los motion graphics como los conocemos hoy. 
En la actualidad no pasa un día en el que en el mundo industrializado no estemos expuestos a gráficas en movimiento, que aunque incorporen aspectos propios de otros medios (tales como fotografía, video, audio) el diseño audiovisual, apenas comienza a tener la importancia de la que gozan otras aplicaciones. En parte también por la incorporación de herramientas para la manipulación del tiempo en software de diseño, la fácil obtención de material videográfico y el abaratamiento de programas de edición de video no lineal y postproducción cinematográfica de calidad.

Se podría decir que la caricatura (entendida como la secuenciación animada bidimensional en medios planos) es más un oficio artístico que una rama del diseño gráfico; y que la animación por computadora o la realizada cuadro por cuadro (técnica conocida como stop motion) es tan compleja y diversa que no se limita a la labor gráfica. Pero aquí se consideran como extensiones posibles, muy populares y sumamente lucrativas del trabajo del diseñador. Básicamente esta segmentación busca incorporar todo aquello que incluya la cuarta dimensión en su proceso, considerando el tiempo como un factor relativo al diseño.

\section{Proyectual}

Es importante hacer una distinción y denominar al campo de acción como "Proyectual", mismo que incorporará todo aquel estudio y trabajo que tiene que ver con el diseño estratégico por un lado, el análisis formal de tendencias, la gestión y la administración de proyectos.

Quizás el análisis de tendencias no sea hasta el momento una profesión per se, y quizás reúna simplemente metodologías que aseguren ventajas competitivas en cualquier rubro, sea artístico, científico, gubernamental, tecnológico o de negocio; por esta razón no será considerada como una "subespecie" dentro del esquema taxonómico aquí propuesto, pero habrá que prestar atención en los próximos años.
La gestión de recursos gráficos (aspecto similar a la dirección de arte) es una labor compleja que requiere de liderazgo y atención a múltiples agentes que funcionan en distintos niveles, a distintas velocidades y que incorporan elementos socioculturales muy diversos. Hasta hace pocos años la mayoría de los proyectos eran desarrollados en ambientes bien definidos, apoyados en estudios de mercado y con poca variabilidad. Cualquier proyecto de gran amplitud ahora es imposible de manejarse por un solo grupo local de individuos con una visión determinada; ahora es necesario abordar las temáticas con un amplio espectro perspectivo que asegure su éxito y trascendencia.

Quizás el término incorpore elementos de la administración de proyectos que "requiera del desarrollo de estándares, investigación, educación y oportunidades en la creación de redes" para la correcta gestión de tareas relevantes (PMI, 2013). Definitivamente los diseñadores involucrados en aspectos corporativos necesitan competencias particulares relacionadas con la planeación estratégica de proyectos, la dirección y gestión de operaciones, con responsabilidades únicas que permitan generar comunicaciones y procesos de alto impacto.

Al tratarse de un análisis superficial y buscar mantener la consistencia con los otros campos de acción, en este esquema se propone ubicar al aspecto Estratégico, la Gestión y la Administración de Proyectos como entidades subdisciplinares independientes aunque muchas de las temáticas se solapen. En su momento habrá que definir qué áreas y qué funciones son pertinentes e inmediatas al diseñador gráfico.

\section{Interactivo}

El diseño de servicios, experiencias y cualquier estudio multidisciplinario que involucre métodos, intereses o temáticas propias del diseño son aún campos de acción relativamente nuevos y poco definidos. Como se comentaba al principio, la disciplina sufre de 
una falta de rigor en su definición y límites como para pretender extender a corto plazo las áreas de trabajo disciplinares.

Cada una de las propuestas que aquí se incluyen destacan el aspecto de interacción entre el diseñador y el medio, que establecerá invariablemente más relaciones con mayor complejidad, similar a lo que comentaba Buchanan (1992) al tratar los sistemas como el último nivel de interacción altamente compleja. Lo mismo sucederá con los nuevos medios que están apenas imaginándose, las tecnologías que continuarán impactando la disciplina y que ampliarán hacia nuevos horizontes nuestra creatividad y trabajo.

\section{Conclusión}

La necesidad de un sistema clasificatorio apropiado, relevante y universal seguirá ahí hasta que se preste atención a este hecho. Como decía Linneo, si no definimos bien las "especies" se corre el riesgo de generar "híbridos" que dificultarán nuestra labor profesional y docente; hecho similar a lo que sucede con la gastronomía molecular, la música atonal, la danza interpretativa, el vorticismo británico, la metafísica o la poesía deconstructiva.

\section{Referencias Bibliográficas}

Buchanan, R. (1992). Wicked Problems in Design Thinking. Design Issues 8, 2. pp. 5-2I.

Bürdeck, B.E. (2002). Diseño. Historia, teoría y práctica del diseño industrial. Barcelona: Gustavo Gili.

Gajendar, U. (2008). The 4 orders of design. En: Ghost in the Pixel. Recuperado de http://www.ghostinthepixel.com/?p=76

Meggs, P.B., \& Purvis, A.W. (20I2). Meggs' history of graphic design. New Jersey: Wiley.

Neumeier, M. (2006). The Brand Gap. Berkeley: New Riders.

Project Management Institute (2013). Guía de los fundamentos para la dirección de proyectos (guía del PMBOK®). Pensilvania: PMI, Inc. 


\section{Design Thinking}

para la innovación social

\author{
Mónica del Carmen Aguilar Tobín
}

El diseño no es estética, el diseño no es un evento, el diseño no es un producto, el diseño no es una experiencia... el diseño es un PROCESO DE PENSAMIENTO"

Corey Ford

Cuando se diseña de una manera enfocada al usuario, es decir, desde un punto de vista antropológico, se debe comprender a la persona de una forma integral, que permita percibir cómo influirá en su vida lo que se está diseñando. El cambio requerido por una comunidad o una persona estará mejor gestionado desde un enfoque de pensamiento del diseño que permita analizar su entorno vital. Este análisis y un modelo del desarrollo que integre tanto los elementos sociales como las experiencias del usuario son fundamentales para el éxito del diseño.

El pensamiento de diseño (DesignThinking) ha sido utilizado como herramienta para desarrollar proyectos de innovación social, ya que al centrarse en el ser humano permite diseñar experiencias para los usuarios y no sólo objetos. Su enfoque ayuda a evitar las soluciones inadecuadas que no están basadas pensando en los deseos o necesidades de una comunidad, así como las propuestas vacías que son a veces más forma que función.

La innovación social es un proyecto de mejora para la sociedad, por lo tanto, necesita métodos que tengan en cuenta el entorno social del usuario y las relaciones en las que se desarrolla. Con la utilización del Design Thinking como método, se consigue mejorar las respuestas a estas necesidades. Dirigiéndose a una sociedad, no a un mercado. 
Al proponer un proyecto de innovación social, se deben tener claros los objetivos y el enfoque que se pretende dar, así como tener una correcta gestión; si no es de esta manera se corre el riesgo de quedarse como un modelo vacío y sin aplicación posible.

\section{Proyectos de innovación social}

Los proyectos de innovación social, son aquellos que implican diseñar herramientas, espacios o procesos de participación que generen una colaboración, una acción o un cambio a favor del bien común. Las oportunidades de proyectos están en todas partes, en procesos que se pueden mejorar, en objetos que se pueden rediseñar para estar al alcance de más personas, en mensajes que, codificados de distinta forma, llegarían a otro sector de la población e impactarían la manera como lo hacen actualmente. Se requiere tener la sensibilidad para detectar estas oportunidades de mejora, de innovación o de ayuda social en aquellos lugares donde es especialmente necesario hacer algo.

Uno de los procesos que más ha aportado para resolver este tipo de problemas, es el Design Thinking, el cual necesita generar la empatía necesaria para aportar las posibles soluciones, desde el lugar correcto, a un problema detectado.

En la formación del diseñador gráfico es necesario trabajar en la elaboración de proyectos de innovación social; actualmente la mayoría de las políticas institucionales a nivel nacional así lo solicitan y en casi todos los diseños curriculares de estas carreras se integra el tema de la responsabilidad social. Debe entoncesdirigir proyectos que hagan una contribución positiva a la sociedad o, al menos, que no sea negativa (Frascara, 2004).

Es muy enriquecedor para un estudiante, trabajar en un proyecto de esta naturaleza, ya que además de contribuir enormemente en su formación disciplinar, lo hace también en su formación integral humana; estos proyectos sensibilizan a los diseñadores, y los hacen tomar conciencia real del problema en cuestión.
Cuando se ofrece una aparente solución a un problema, en la cual el diseñador no ha tenido la suficiente empatía con el usuario, no ha valorado el problema desde el punto de vista del mismo, esta solución definitivamente no funciona. Desde una señalética imposible de descifrar, hasta carteles que no se pueden leer a una distancia corta; el entorno está lleno de propuestas de diseño en las que no se pensó en el usuario, por lo tanto es necesario formar al estudiante actual consciente de que sus propuestas deben estar pensadas en alguien más que los jurados de un concurso, deben de ir más allá de la forma y centrarse en la función, aunque no por eso, estar alejados de lo estético.

De acuerdo a la metodología desarrollada por Tim Brown, el proceso debe comenzar y terminar con el usuario; enfocar las propuestas desde la creatividad utilizando los métodos no convencionales. El Design Thinking tiene como característica principal generar empatía con el usuario, ubicarse en su contexto y generar ideas que puedan aportar una solución real al problema. Este enfoque, que es tan extendido en la actualidad exige que en la formación tradicional de los diseñadores, ya sean gráficos o industriales tenga un cambio para que asuman este tipo de temática para la resolución de problemas.

\section{Proceso Creativo del Design Thinking}

El Design thinking es un enfoque que utiliza la sensibilidad del diseñador y sus métodos de resolución de problemas para satisfacer las necesidades de las personas de un modo tecnológicamente factible y económicamente viable (Brown, s.f.)

De acuerdo al Hasso Plattner Institute of Design of Standford (2013) el proceso creativo del Design thinking tiene las siguientes premisas:

- Enfoque en el Usuario: tener empatía por las personas para las cuales se está diseñando y retroalimentación por parte de éstas, lo cual es fundamental para lograr un buen diseño. 
- Muéstralo, no lo digas: comunicar la idea de una manera impactante, creando experiencias, contando buenas historias y haciendo representaciones ilustrativas.

- Colaboración radical: conformar equipos de personas de diferentes disciplinas y puntos de vista, ya que la diversidad enriquece las ideas y los resultados.

- Conciencia del proceso: tener claro el proceso del diseño, y saber qué métodos utilizar en cada fase.

- Cultura de los Prototipos: hacer prototipos no es simplemente una manera de validar las ideas; es una parte integral del proceso de innovación.

- Incitar a la acción: pasar del pensamiento a la acción.

Asimismo, el Hasso Plattner Institute of Design at Standford (2013), identifica cinco pasos elementales para el Design Thinking:

Empatizar: Es la base del proceso de diseño centrado en el usuario. Para lograr una adecuada empatía, hay que conocer a los usuarios en el contexto de vida, observar sin influir. Como diseñador, los problemas que se tratan de resolver no son propios, hay que hacer un esfuerzo por comprender al usuario, entender sus necesidades, tanto físicas como emocionales, entender su perspectiva y darse cuenta de qué es significativo para él. De esta manera, el mismo usuario es el que inspira y direcciona las ideas.

Definir: Se refiere a la correcta determinación del desafío del proyecto basado en lo aprendido del usuario y su contexto, se debe tener bien definido el problema de diseño que se resolverá. Solamente enmarcando el problema de una manera adecuada, se podrá crear la solución correcta; se deberá enmarcar el problema desde un enfoque directo, ser inspirador para el equipo de trabajo, así como generar criterios para poder evaluar ideas, seleccionarlas y depurarlas.
Idear: En esta fase comienza el proceso de diseño, así como el surgimiento de ideas. Al concluir esta etapa, se tienen como resultados los conceptos y los recursos para poder prototipar y crear soluciones innovadoras. Todas las ideas son válidas, y se combina desde el pensamiento racional, la imaginación hasta pensamientos conscientes e inconscientes.

Se desarrolla la lluvia de ideas (brainstorm) y se construyen ideas sobre otras previas, lo cual da como resultado una variedad de alternativas para elegir como posibles soluciones. Se puede trabajar con métodos como croquis, mapas mentales, prototipos, storyboards, etc. Sin embargo, es muy importante saber separar la generación de ideas de la evaluación de ideas.

La creación de múltiples ideas permite pensar sobre soluciones obvias y aumentar con ello el potencial de innovación; aprovechar las distintas visiones del equipo; y descubrir áreas inesperadas de exploración creando mayores opciones para innovar.

Prototipar: En esta fase se generan elementos que arro $\neg$ jan mucha información, como dibujos, artefactos, o maquetas que responden muchas preguntas y acercan a la solución final. Se trata de un objeto o cualquier cosa con lo que el usuario experimenta y se da una idea de la posible solución, experimentando con las características de uso, forma y función. Es un proceso mejorable y modificable que retroalimenta la toma de decisiones en el proceso de diseño. En esta fase el proyecto se va refinando y puliendo, por lo que es de suma importancia estar atento a las respuestas de interacción del prototipo con el usuario y formular los criterios de evaluación que arrojen la información adecuada para posibles modificaciones al diseño.

Evaluar: En esta etapa se solicita la retroalimentación por parte de los usuarios y el resto del equipo, y se tiene la oportunidad de refinar las soluciones y mejorarlas. 
Muchas veces como resultado de la evaluación se vuelve a la mesa de dibujo, o se redefine el punto de vista; los resultados pueden revelar que no solo es errónea la solución, sino que está mal enmarcado el problema.

La mejor manera de evaluar, es cuando el usuario tiene contacto con el prototipo sin instrucción alguna (no lo digas, muéstralo), la persona deberá interpretar el objeto de diseño e interactuar con él. Lo ideal es crear una experiencia lo más aproximada al contexto real de aplicación del diseño, lo que revelará más información. Es conveniente que el usuario pruebe varios prototipos, compare y otorgue información sobre ellos. Con base en los resultados se puede volver a la etapa de definición del problema o a la generación de ideas, según sea el caso.

\section{Design Thinking como recurso didáctico}

Se propone la aplicación del Design Thinking como recurso didáctico en la asignatura de Taller de Diseño Gráfico Integral V, impartida en la Licenciatura en Diseño Gráfico de la Universidad de Sonora, implementando un ejercicio en el cual los estudiantes realicen un proyecto que solvente soluciones a problemas sociales cotidianos de una manera innovadora y creativa.

El objetivo del ejercicio es que el estudiante desarrolle su percepción a partir de la observación continua, así como sus habilidades analíticas, aumentando su capacidad para definir problemas e identificar oportunidades creativas en el campo del diseño.

La dinámica del ejercicio se llevará a cabo de la siguiente manera: los estudiantes trabajando en equipos de tres o cuatro personas, deberán abordar problemáticas sociales a las que ellos puedan aportar una solución, como la contaminación visual, la integración de personas con capacidades diferentes, la limpieza de las playas, entre otras.

Una vez definido el problema de cada equipo, contarán con asesoría y orientación por parte del profesor titular de la materia, y asesores externos especializados, dependiendo de cada tipo de problema.

Cada equipo, siguiendo los pasos elementales del Design Thinking, deberá realizar actividades de acuerdo a cada una de las etapas, las cuales se describen a continuación:

Empatizar: En esta etapa, que también puede ser llamada de sensibilización, los estudiantes hacen un reconocimiento de campo, primero en el lugar sobre el que se trabajará, ya sea el centro histórico de la ciudad, una playa o alguna comunidad de las afueras de la ciudad. Se entrevistan con las personas, toman fotografías de los lugares problemáticos, utilizan el transporte público, es decir, viven un poco el contexto del problema.

Dinámica de trabajo: inmersión cognitiva, interacción constructiva, observación encubierta, entrevistas, visualización empática, mapas mentales, guión de la entrevista, mapas de empatía.

Definir: En esta etapa los estudiantes detectan, plantean y definen cuál segmento del problema puede solucionarse desde su disciplina.

Dinámica de trabajo: Habrá que realizar una definición del perfil de usuario, crear un Moodboard, algunas actividades de reactivación o recopilación de historias.

Idear: Surgen las primeras aportaciones del equipo, conceptos e ideas surgidas de la parte creativa y desde métodos no convencionales, hasta los más racionales. No se elimina ninguna idea por más absurda que parezca, hasta la etapa de la evaluación de las mismas. Se pide respeto al punto de vista de cada compañero para hacer la evaluación correspondiente con argumentos válidos. 
Dinámica de trabajo: boceto en grupo, tarjetas, maquetas, boceto de prototipos, dibujo en grupo, lluvia de ideas, primeras selecciones, "sombreros para pensar"

Prototipar: En diseño gráfico, esta etapa es el equivalente a los bocetos finos, o los dummies, dependiendo de cada caso. Lo importante de esta fase es la interacción, primero entre los miembros del equipo, con los demás compañeros, y luego se prueba con el usuario final, recibiendo la retroalimentación correspondiente que dará lugar a la evaluación de seguir o volver a una etapa anterior.

Dinámica de trabajo: aplicación del perfil del usuario, inmersión cognitiva, interacción constructiva, boceto en grupo, mapa del sistema, matriz de motivaciones, casos de uso.

Evaluar: Una vez obtenida la retroalimentación por parte de los usuarios finales, se definen las posibles modificaciones, o incluso el replanteamiento de la solución, para recomenzar o si todo sale bien, se procede a la implementación del proyecto.

Técnicas de trabajo: prueba de uso, prototipo de servicio, observación encubierta, juego de roles, dummys, maquetas, entre otras.

Al final del ejercicio, se aplicarán las soluciones y serán puestas en práctica por cada equipo en el entorno correspondiente. La evaluación se hará por parte de los usuarios finales en el tenor del funcionamiento del proyecto. El profesor por su parte, evaluará cada una de las fases del proyecto y el resultado final.

\section{Conclusiones}

El Design Thinking, metodología que nace desde la ingeniería con objetivos comerciales, ha sido exitosa ya que introduce prácticas de diseño centradas en el ser humano y ofrece una manera diferente de detectar necesidades, permitiendo aportar soluciones creativas. Se ha llevado a diferentes ámbitos, buscando siempre la empatía con el usuario final. Los proyectos de innovación social no son la excepción y, dadas las características de estos, el Design Thinking resulta muy útil en el aporte de soluciones.

Cuando este proceso se lleva a cabo desde el taller de diseño, el estudiante aprende del usuario, sus intereses y necesidades, obteniendo así importantes acercamientos cognitivos intuitivos, creando con ello un producto adaptado al usuario y no de manera inversa, en el que este tenga que adaptarse al producto. Esto se logra gracias a que el estudiante realiza una investigación más interactiva, evita los estereotipos de usuarios y también adquiere una importante habilidad para trabajar con la complejidad y la incertidumbre.

La participación de los estudiantes en este tipo de proyectos impacta positivamente en su formación ética y humana, ayuda al diseñador a entender la sociedad, a ser conscientes de los problemas de su entorno y a proponer soluciones viables desde la perspectiva de su profesión.

\section{Referencias bibliográficas}

Frascara, J. (1997). Diseño gráfico para la gente. Buenos Aires: Editorial Infinito.

Lupton, E. (20II). Graphic Design Thinking: Beyond Brainstorming. Princeton: Princeton Architectural Press.

Vita, M. (2003). El sistema de las imágenes. Barcelona: Paidós.

V.A. (2014). Bootcamp Bootleg. Stanford, California: Hasso Plattner, Institute of Design at Stanford. Recuperado de http://dschool.stanford.edu/wp-content/uploads/201//03/ BootcampBootleg20IOv2SLIM.pdf 


\section{Aplicación del proceso de Design Thinking en el diseño gráfico}

\author{
Alejandra Rivera Arredondo
}

En este capítulo se hablará de diversas consideraciones respecto a la definición del diseño desde la visión de varios autores, su papel como disciplina y cómo estas ideas han conducido a la creación de nuevas definiciones y nuevos planteamientos sobre los procesos de diseño, específicamente, el Design Thinking. Finalmente, se explicará brevemente una propuesta para su aplicación al diseño gráfico.

\section{Consideraciones alrededor del diseño}

Uno de los comentarios más fuertes respecto al destino que ha tenido el diseño como disciplina, viene de Heskett (2005) quien menciona que tras varias décadas de emplear el diseño para solucionar problemas de comunicación de las crecientes sociedades de consumo en economías capitalistas, la disciplina se ha transformado en algo "banal e intrascendente", lo cual ha provocado la generación de productos culturalmente irrelevantes, inútiles y por supuesto, grandes cantidades de basura (Press y Cooper, 2009).

Por otra parte, Margolin (1998) habla sobre la complejidad de la que ha sido sujeto el diseño; afirma que los límites entre el diseño gráfico y otras disciplinas no sólo han comenzado a difuminarse, sino que se han realizado uniones entre ellas. Esto es reflejo de la expansión del ámbito del diseño y de la complejidad resultante de la adición de prácticas y saberes de otras disciplinas.

Sin embargo, estas ideas no son tan recientes. Desde 1970, autores como Victor Papanek y Gui Bonsiepe se han preocupado por evidenciar la necesidad de un cambio en la concepción y la práctica del diseño como disciplina. 
Por ejemplo, Papanek (2005) define al diseño como "un esfuerzo intuitivo y consciente para establecer un orden significativo" y señala que el diseño debe responder a una responsabilidad con la ecología y la sociedad; debe ser duradero y no debe fomentar el consumo. Esta definición acerca al diseño hacia el tema de la sustentabilidad y añade criterios éticos que deben estar presentes en la práctica de la disciplina.

Posteriormente, otros autores, como Ricard (I982), Beltrán (1995) y Heskett (2005) e instituciones como International Council of Graphic Design ICOGRADA (20I3), han buscado redefinir el diseño con el fin de encontrar un equilibrio entre la práctica profesional y el sentido ético.

Estos autores consideran al diseño y a la capacidad creativa, una actividad inherente al ser humano y por lo tanto, posible en todos. Asimismo, mencionan que el acto de diseñar constituye un proveedor de sentido para el ser humano, pero también un recurso para su mejoramiento económico, social y cultural, el cual debe, ante todo, respetar y favorecer al ser humano y a la naturaleza.

Estas ideas, colocan al diseñador en un punto de alta importancia; consideran al diseñador como un ente que influye en la formación del ámbito social de los seres humanos, además, da forma y crea objetos, sistemas y ambientes. Dicho esto, Margolin (2007) considera que es tarea del diseñador comprometerse en la creación del futuro.

Una de las propuestas más importantes y acertadas en redefinir el diseño gráfico, lo hace ICOGRADA (20II), donde establece, en once puntos, una nueva definición del diseño gráfico en el contexto de la creciente complejidad y plantea los aspectos éticos que deben guiar a la disciplina.

Por ejemplo, acoge en su definición todas las nuevas ramas del diseño gráfico, como el diseño de animación, gráfica para televisión y diseño de interfaz, entre otros. También, menciona que junto a los cambios tecnológicos, la diversidad de posibilidades en cuanto a resultados visuales y la influencia de aspectos sociales, culturales, ambientales y económicos, han provocado que los problemas de diseño sean cada vez más complejos.

Entre los once puntos del manifiesto de ICOGRADA (20II) es importante subrayar los siguientes: la creación, de parte del diseñador gráfico, de la vida y el paisaje visual del comercio y la cultura en un equilibrio estable; la creación de significados; la identificación, definición y solución de problemas a través de un pensamiento crítico, la creatividad, la experimentación y la evaluación; el respeto por la diversidad humana, ambiental y cultural; y el uso de principios éticos donde se tomen en cuenta los efectos del diseño en la humanidad y el medio ambiente. Estos puntos resumen las preocupaciones que desde Papanek se presentaban como reto para la profesión.

Hasta aquí se ha hablado sobre las ideas que están alrededor de esta redefinición del diseño gráfico, donde destaca su acercamiento a prácticas sustentables y criterios éticos que consideren los efectos del diseño en el ser humano, la sociedad y el ámbito económico.

En la siguiente sección, se comentará sobre las propuestas prácticas que han surgido, tomando como base los planteamientos antes comentados, como el Human Centered Design o diseño centrado en el ser humano y el Design Thinking o pensamiento de diseño.

\section{De la teoría a la práctica: \\ los procesos centrados en el humano}

Una de las alternativas que responden a estas preocupaciones, es el "diseño centrado en el ser humano" o Human Centered Design (HCD), que como su nombre lo indica, la base de su proceso de diseño es el ser humano.

Dentro de esta clasificación de procesos centrados en el ser humano, se encuentra el Design Thinking, que Brown (s.f.) describe 
como una ventaja competitiva en los negocios y un método para generar innovación que utiliza los procesos empleados por el diseñador para conjugar las necesidades de la gente con lo que es tecnológica y económicamente viable.

Este proceso de diseño está conformado por tres etapas, las cuales se explicarán brevemente. En la primera fase, inspiration, se define el problema de diseño y concluye con la creación de un brief. En la segunda, ideation, se generan, desarrollan y evalúan las ideas. Y finalmente, en la última, implementation, se recorre el camino que conduce al diseño desde su etapa proyectual hasta su transformación en un producto o servicio final en contacto con sus usuarios.

Respecto a la aplicación de este proceso, este ha sido utilizado principalmente en el diseño industrial, diseño de producto, negocios, entre otros. Sin embargo, en diseño gráfico, aún no se han desarrollado metodologías que lo apliquen. Es por ello, que aquí se plantea el uso del modelo del Design Thinking en el diseño gráfico como una manera de asentar una metodología que contenga y conduzca los intereses y preocupaciones de ICOGRADA (20II) y que adicionalmente, esté dirigido tanto a la innovación como a la sustentabilidad.

\section{Propuesta de aplicación}

A continuación se explica una propuesta de aplicación del modelo del Design Thinking en el Diseño Gráfico. Se enfatizan los pasos intermedios para lograr los objetivos correspondientes a cada etapa de este proceso.

Las tres etapas que conforman este proceso son: I) inspiración, 2) generación de ideas y 3) ejecución.

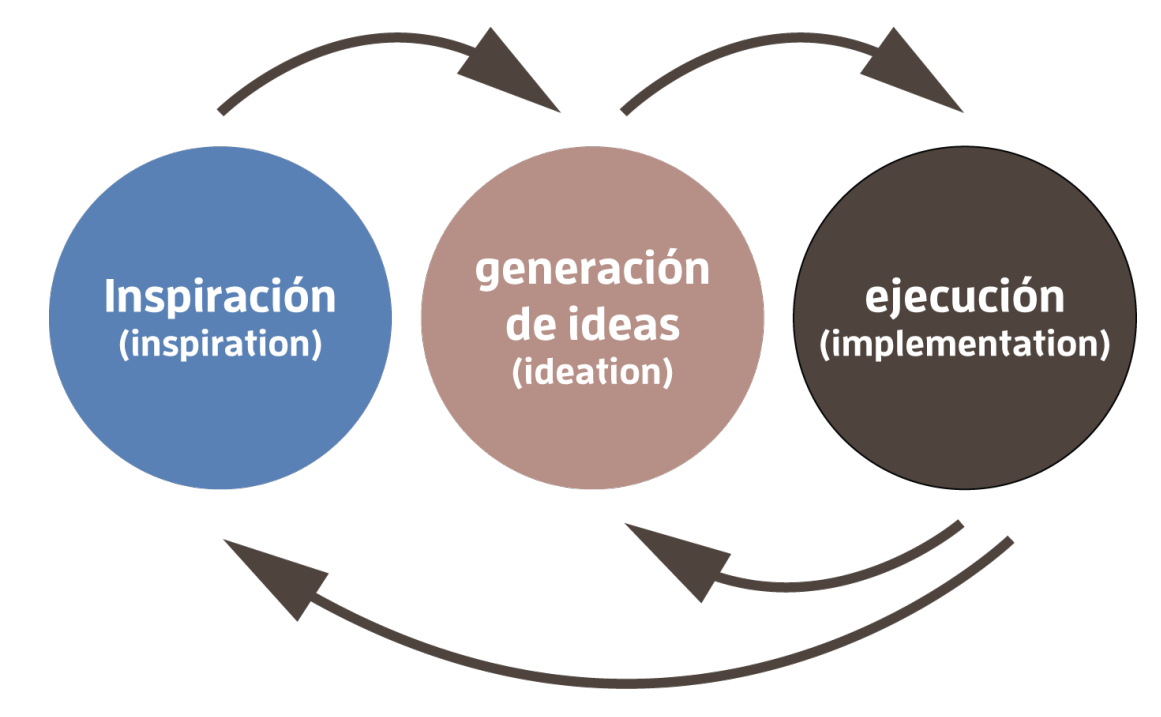

Figura I. Etapas del Design Thinking.

Para la primer etapa, llamada Inspiración, se sugieren los siguientes pasos:

- conexión con las necesidades y deseos de las personas

- identificación del problema

- y finalmente, creación del brief

Para empezar el proyecto de diseño gráfico, y considerando que este es un proceso centrado en el ser humano, es imprescindible iniciar obteniendo información dirigida a conocer los deseos y necesidades de las personas. Para ello, se pueden emplear técnicas etnográficas de investigación como encuestas, entrevistas y observación de actitudes o escenarios, o bien, a través del cliente. (Ver Fig. 2).

Además, se recomienda el uso de los lentes de empatía, para lograr acercarse a los problemas, no sólo del medio ambiente, sino de la empresa y la sociedad. (Ver Fig. 3).

Finalmente, esta etapa concluye con el análisis de la información obtenida y la creación de un brief. Este ayuda al diseñador o equipo de diseño a tener un punto de partida para el proceso de diseño. 


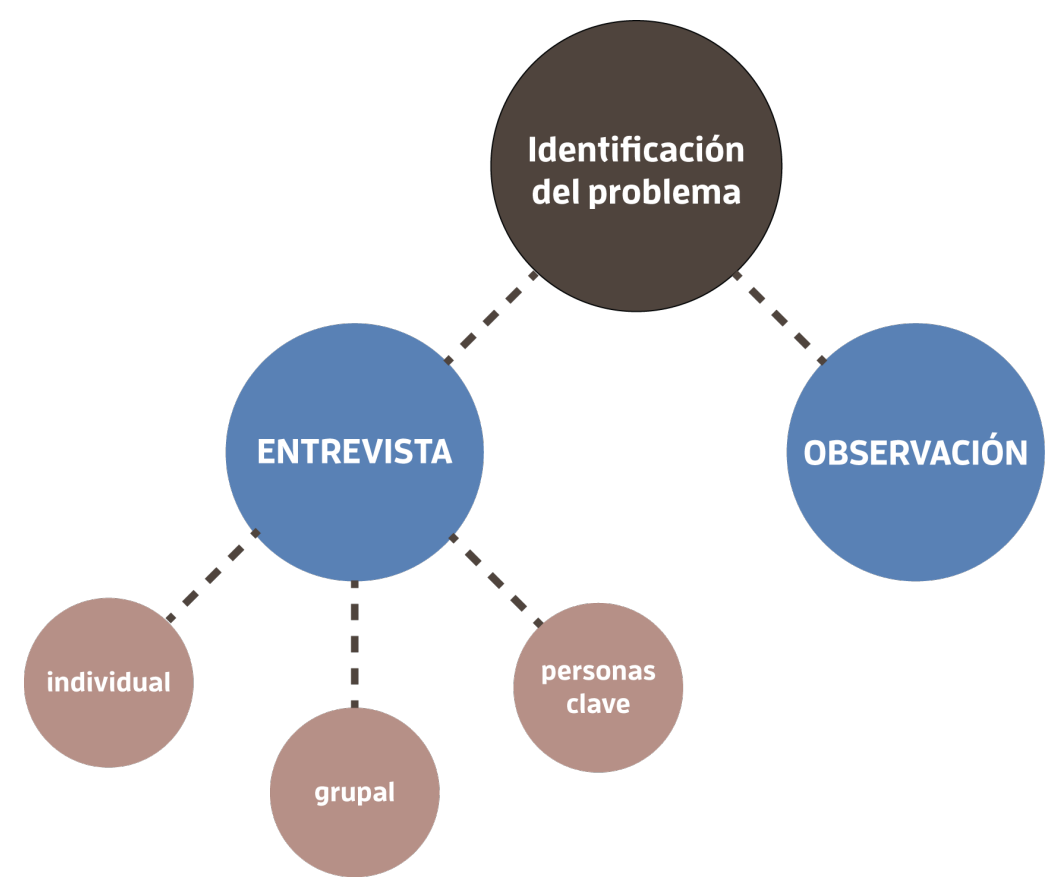

Figura 2. Identificación del problema.

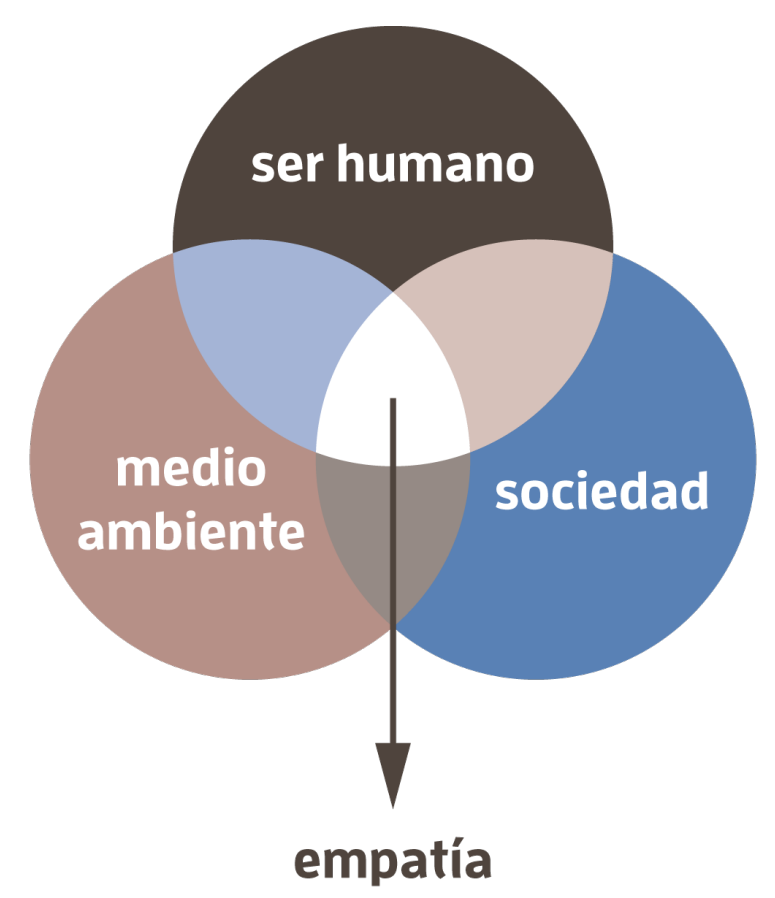

uso de "lentes" planteado por el modelo HCD

Figura 3. Lentes de empatía.
El brief es un documento escrito en el cual, se incluyen los objetivos y las metas que se buscan alcanzar con el proyecto, así como información pertinente como: antecedentes de la empresa, problema de diseño, especificaciones, atributos, información sobre el mercado y el consumidor, costos, presupuestos y lapsos de tiempo (Bruce, Cooper y Vazquez, 1999). En él se concentra gran cantidad de la información dada por la empresa, como aquella procesada por el diseñador a través de las técnicas etnográficas de investigación.

Adicionalmente, se puede realizar un brief en el que se especifiquen con mayor detalle las características deseadas para el diseño, como descripciones, valores, conceptos, adjetivos, entre otros.

Es importante recordar que este documento no es estático, al contrario, como menciona Brown y Wyatt (20I0), es un instrumento dinámico que permite cambios conforme se va avanzando en el proceso de diseño.

Tanto el cliente, como el diseñador, deben estar de acuerdo con la información que se plantea en el brief. Una breve entrevista con el cliente puede ser de gran ayuda para redefinir metas u objetivos. Para ello, la inmersión del diseñador en el contexto del cliente, así como la empatía a los problemas y circunstancias puede llevar al diseñador a encontrar nuevas alternativas para la solución de los problemas de diseño.

Por último, el brief también es igualmente útil para evaluar cada etapa del proceso de diseño, y hacer una revisión al final del mismo. Por ello, sugiere que se realice una breve evaluación al cierre de cada paso o etapa.

Se ha explicado brevemente las actividades de la primer etapa, llamada Inspiración. Se continuará con la segunda etapa llamada Generación de ideas, donde se incluyen las siguientes técnicas: lluvia de ideas, mapa mental, focus group, verbos de acción, semiótica, 6 sombreros para pensar y matriz heurística. 
El objetivo de la etapa de Generación de Ideas, es llevar a cabo un proceso de síntesis de la información obtenida en la etapa anterior para desarrollar conceptos que resuelvan el problema de diseño planteado en el brief. Para lo anterior se emplean métodos y técnicas que estimulen el trabajo creativo.

Una recomendación es el trabajo a través de grupos multidisciplinarios, de esta manera, se pueden abordar los problemas de diseño con la visión de disciplinas diferentes y lograr ideas variadas y más complejas.

Por otro lado, la representación visual de las ideas resulta de gran ayuda para esta parte del proceso. La realización de bocetos, esquemas, relaciones de palabras y conceptos presentados visualmente ayuda a organizarlos, relacionarlos y agruparlos. Hacer bocetos es una forma de explorar el problema y la solución juntos, y hacer avances al enfrentarse a la complejidad de los problemas de diseño (Cross, 20II).

Existe una gran cantidad de técnicas para el desarrollo de la creatividad, sin embargo, hay algunas que son frecuentemente utilizadas en el diseño gráfico. Una de ellas es el brainstorming o Lluvia de ideas, término acuñado por Alex F. Osborn en 1953 (Lupton, 20II), que consiste en elegir un tópico y desarrollar ideas alrededor de éste. La ventaja es que es una técnica versátil y necesita pocos materiales para llevarla a cabo: un pizarrón o postits y plumones de colores.

También, Mapa mental o Mind mapping, desarrollada por Tony Buzan, permite explorar ideas de manera rápida y hacer asociaciones entre ellas de manera libre. Al igual que el brainstorming, requiere de pocos materiales.

La técnica del Focus group se establece como una conversación guiada entre un grupo de usuarios para conocer sus ideas respecto a un tópico específico. Puede ser empleada tanto para definir los objetivos de un proyecto de diseño, como para evaluar el diseño final. Sin embargo, se debe cuidar no dirigir las respues- tas de los participantes, ni imponer opiniones dominantes de otros participantes porque se obtendrían resultados no confiables.

Los Verbos de acción, es una técnica útil cuando se desean hacer variaciones de un concepto, idea o diseño. Consiste en la exposición del tema central al cual se aplican una serie de verbos, llamados "de acción", como por ejemplo: adaptar, alterar, modificar, magnificar, sustituir, combinar, entre otros.

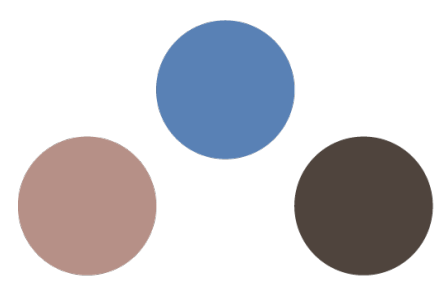

combinar

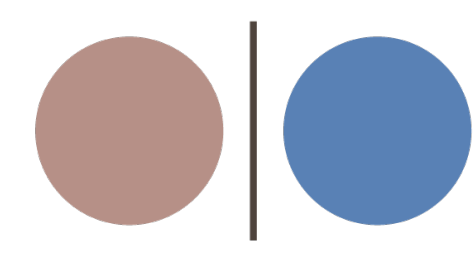

dividir

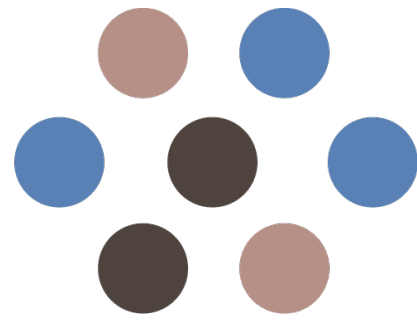

multiplicar
Figura 4.Verbos de acción

Por otra parte, el uso de la semiótica es útil para generar formas con significado. El uso de símbolos en el diseño es muy efectivo porque responde a convenciones culturales, sin embargo, se deben elegir cuidadosamente y considerar el contexto en el que se va a mostrar.

Los Seis sombreros para pensar de Edward De Bono, se relaciona con la intención consciente de generar una idea proponiendo diferentes puntos de vista, los cuales son representados a través de sombreros de diferentes colores (De Bono, 1994). Por ejemplo, el sombrero blanco representa al pensamiento enfocado en los datos y la información, se limita a pensar en los datos existentes. El sombrero rojo se relaciona con los sentimientos, las emociones, los presentimientos e intuiciones; aquí el grupo es capaz de expresar sus sentimientos sin necesidad de ser disfrazados 
con fundamentos lógicos. La ventaja de ésta técnica es que hace a un lado la posibilidad de tomar una discusión de manera personal y permite que los integrantes no se sientan en la necesidad de defender una idea; también permite que los integrantes del grupo piensen de otras maneras diferentes a las que acostumbran.

Por último, la Matriz heurística, es una técnica que sirve para desarrollar y combinar ideas gráficas. Esta inicia con una serie de palabras, conceptos o valores tomados del brief de diseño, elegidas previamente. Primero se realiza la representación visual de cada uno de los conceptos o valores $y$, a través de la matriz heurística, se van realizando combinaciones gráficas.

Se ha explicado en forma muy breve las técnicas propuestas para la etapa de Generación de ideas. Es claro que existen muchas técnicas para desarrollar la creatividad y todas son útiles para llevar a cabo el objetivo de esta etapa.

La tercer y última etapa, la de Ejecución, tiene como objetivo dar forma a las ideas generadas en la etapa anterior. Para ello, los elementos de diseño más básicos, como la tipografía, el color, la forma, entre otros, deben coincidir con los significados que se buscan expresar en el diseño asentados en el brief de diseño.

Dentro de esta última etapa, se realizan consideraciones respecto a los temas de sustentabilidad, o el lente de empatía relacionado con el medio ambiente, el cual refiere a reducir al mínimo el material de desecho, elegir medios de impresión y encuadernación que sean menos contaminantes, diseñar para la longevidad y la reutilización, optar por proveedores que usen energías renovables y manejen prácticas equitativas y respetuosas con el medio ambiente, entre otros.

En una siguiente etapa se realizan pruebas o prototipos del diseño. Aquí pueden entrar pruebas de color, de impresión, así como legibilidad, claridad, incluso se puede realizar una prueba de la recepción del diseño a través de técnicas mencionadas anteriormente, como Focus groups y entrevistas.
Posteriormente, se toma la información recabada en las pruebas de diseño para analizar si existen elementos que deben ser modificados o cambiados totalmente. Este proceso de realización de pruebas y corrección, se puede repetir las veces que sea necesario con el fin de obtener un diseño más efectivo. Retomar información de la primer y segunda etapa también puede ser útil al momento de encontrar fallas en un diseño, asimismo, reconsiderar los lentes de empatía explicados en la etapa I, puede ayudar a redirigir los objetivos del diseño.

Por último, se realiza un proceso de evaluación del diseño terminado. Tomando como referencia la evaluación planteada por Frías (20II), se incluyen parámetros como: funcionalidad, calidad, durabilidad, costo y orden o estética. Empleando una escala Likert del I al 5, siendo el l el menor y 5 el mayor, se evalúa cada punto de cada diseño.

Tabla I. Escala Likert (Frías 20II).

\begin{tabular}{|c|c|c|}
\hline PARÁMETRO & Diseño A & Diseño B \\
\hline Funcionalidad & 5 & 2 \\
\hline Calidad & 3 & 1 \\
\hline Durabilidad & 5 & 4 \\
\hline Costo & 4 & 4 \\
\hline Orden / Estética & 5 & 3 \\
\hline Otro & 0 & 0 \\
\hline TOTAL & 22 & 14 \\
\hline
\end{tabular}


Esta última evaluación puede servir al cliente para elegir una de las opciones propuestas por el equipo de diseño; también, puede aplicarse a los usuarios finales para conocer cuál de las opciones tendrá mayor impacto y mejor recepción. Otra evaluación puede ser realizada cuando el diseño ya ha llegado a sus usuarios finales en el contexto del mercado; esta puede servir para lograr un aprendizaje entre el equipo de diseño y arroje información útil para la planeación de proyectos futuros.

\section{Ventajas y posibilidades del uso del Design Thinking}

En la sección anterior se explicaron brevemente cada una de las etapas con los pasos intermedios propuestos para la aplicación del Design Thinking en el Diseño Gráfico. A continuación se mencionan algunas de las ventajas y posibilidades del uso de este proceso en las áreas profesional, educativa y de manera específica, en el diseño gráfico.

En el trabajo del profesional, la ventaja que le ofrece es, por un lado, lograr un trabajo ordenado que le permita tomar decisiones de diseño basadas en información, y por otro, que esta forma de trabajo le ofrezca una manera más contundente de justificar un proyecto ante un cliente, y también, que el cliente tenga confianza en los resultados del diseño.

En el ámbito de la enseñanza, puede encontrar su utilidad en un ordenamiento del aprendizaje para los alumnos que sirva también, al profesor. Por un lado, posibilita el desarrollo de un tipo de pensamiento que permite al alumno identificar y analizar información oportuna para reconocer y definir problemas de diseño. También, puede representar una herramienta útil para abordar problemas de diseño diversos tanto como estudiante como en su futuro trabajo profesional y con un enfoque dirigido hacia el ser humano.
Por último, una de las principales ventajas de utilizar el Desing Thinking en el Diseño Gráfico es el uso de un proceso de diseño que va acorde con las directrices planteadas por ICOGRADA en su manifiesto del 20Il, en el que se enfatizan las consideraciones éticas hacia el ser humano, el medio ambiente y la sociedad, así como el tema de la sustentabilidad y la innovación. Estos planteamientos llevados a la práctica permitirán una nueva forma de entender la profesión, donde el diseñador esté consciente de su influencia en la vida social y cultural, así como de su impacto en el medio ambiente, que sea capaz de entender su entorno e incidir en él desde esta conciencia, y así lograr ser un agente de cambio dentro de la sociedad. 


\section{Referencias bibliográficas}

Beltrán, F. (1995). Acerca del diseño. La Habana: Unión.

Brown, T. (s.f.). Our approach: Design Thinking. Recuperado de http://www.ideo.com/about/

Brown, T., \& Wyatt, J. (20I0). Design Thinking for Social Innovation. Stanford Social Innovation Review. Recuperado de http://www. ideo.com/images/uploads/thoughts/20IO_SSIR_DesignThinking. pdf

Bruce, M., Cooper, R., \& Vazquez, D. (1999). Effective Design Management for Small Businesses. Design Studies 20. 297-315.

Cross, N. (20II). Design thinking. Inglaterra: Berg.

De Bono, E. (1994). El pensamiento creativo. El poder del pensamiento lateral para la creación de nuevas ideas. México: Paidós.

Frías, J. (2OII). Evaluando el diseño. En: FOROALFA. Recuperado de $\mathrm{http} / / /$ foroalfa.org/articulos/evaluando-el-diseno

Heskett, J.(2005). El diseño en la vida cotidiana. Barcelona: Gustavo Gili.
ICOGRADA (20II). Design Education Manifesto. Recuperado de http://www.ico-d.org/database/files/library/ IcogradaEducationManifesto_20II.pdf

ICOGRADA (20I3). Defining the Profession. Recuperado de http:// www.ico-d.org/about/index\#defining-the-profession

Lupton, E. (2OII). Graphic design thinking: Beyond brainstorming. New York: Princeton Architectural Press.

Margolin, V. (1998). Design Studies for a New Doctorat., En: S. Heller (2005), The Education of a Graphic Designer. New York: Allworth Press.

Margolin, V. (2007). Design, the Future and the Human Spirit. Design Issues, 23 (3), 4-15.

Papanek, V. (2005). Design for the real world. Human ecology and human change. Chicago: Academy Chicago Publishers.

Press, M., \& Cooper, R.( 2009). El diseño como experiencia. Barcelona: Gustavo Gili.

Ricard, A. (1982). Diseño ¿Por qué?. España: Gustavo Gili. 


\section{Agentes dinámicos en la enseñanza del diseño gráfico}

ISBN 978-607-518-134-9

ISBN 978-607-96359-2-3

DOII0.294IO/QTP.I5.OI

Este libro se terminó en Septiembre de 2015.

Su edición y diseño estuvieron a cargo de:

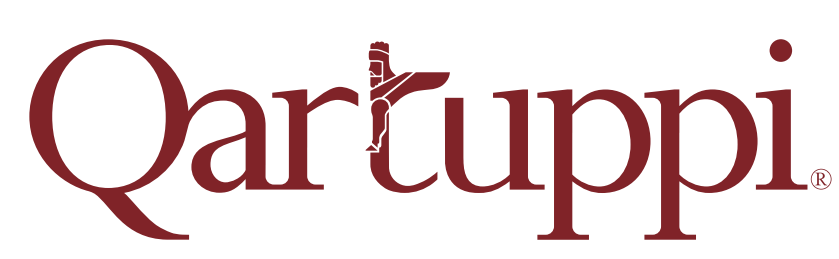

Qartuppi, S. de R.L. de C.V.

http://www.qartuppi.com 
UNIVERSIDAD DE SONORA

QARTUPPI, S. de R.L. de C.V.

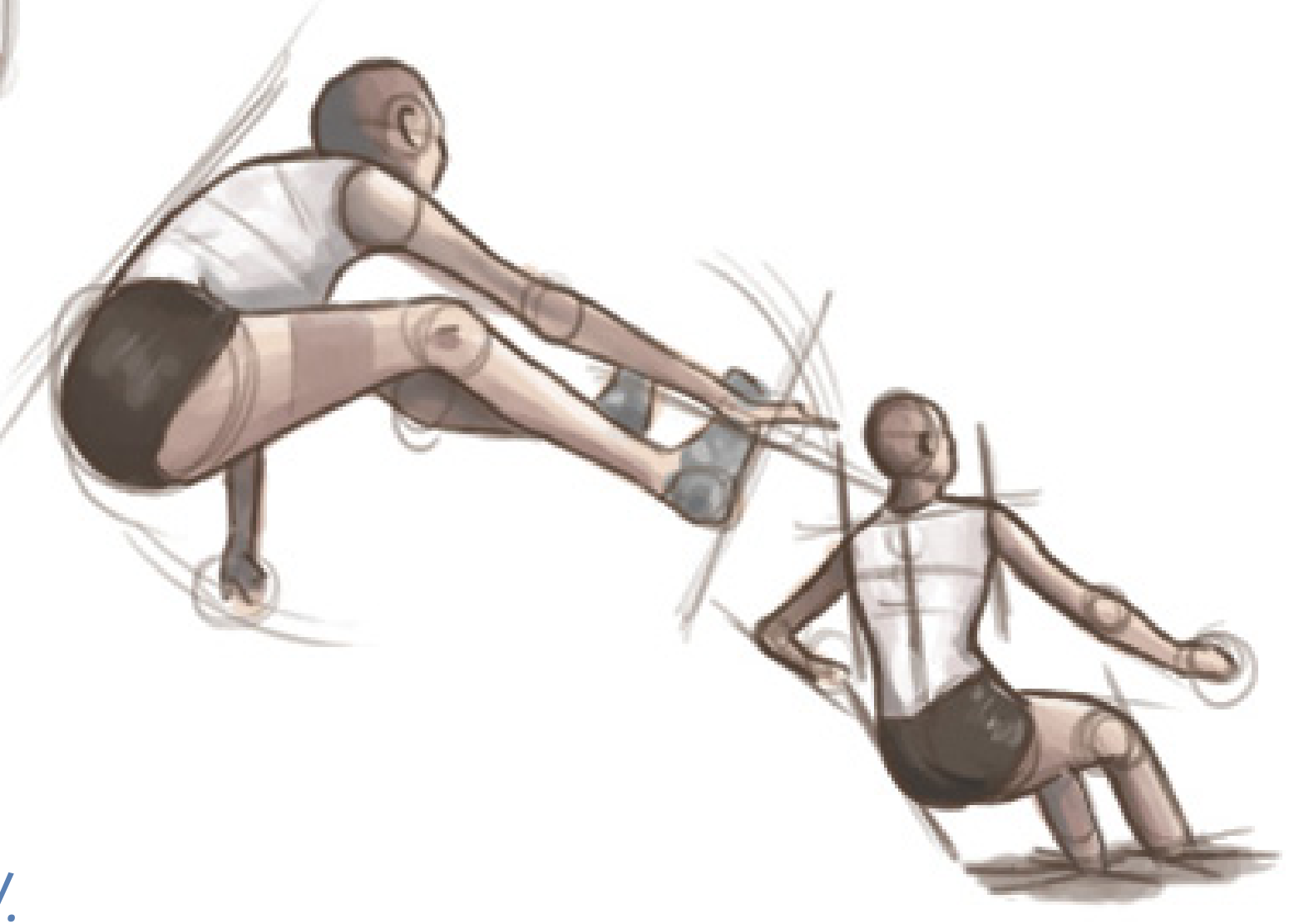

